DEPARTMENT OF THE INTERIOR UNITED STATES GEOLOGICAL SURVEY GEORGE OTIS SMITH, DiRECTOR

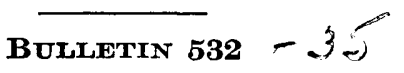

THE

\title{
KOYUKUK-CHANDALAR REGION
}

\author{
ALASKA
}

BY

A. G. MADDREN

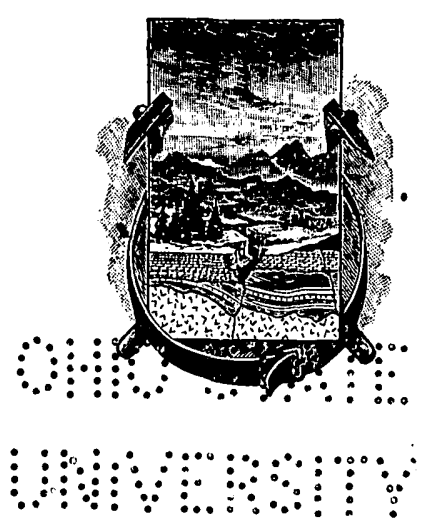

WASH INGTON

GOVERNMENT PRINTING OFFICE

1913 


$$
\begin{aligned}
& \text { Q. } 15 \\
& \text { (1) } \\
& \text { non, 5-30 } 605 \\
& \text { cofpr } 4
\end{aligned}
$$

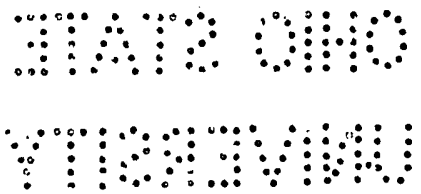




\section{CONTENTS.}

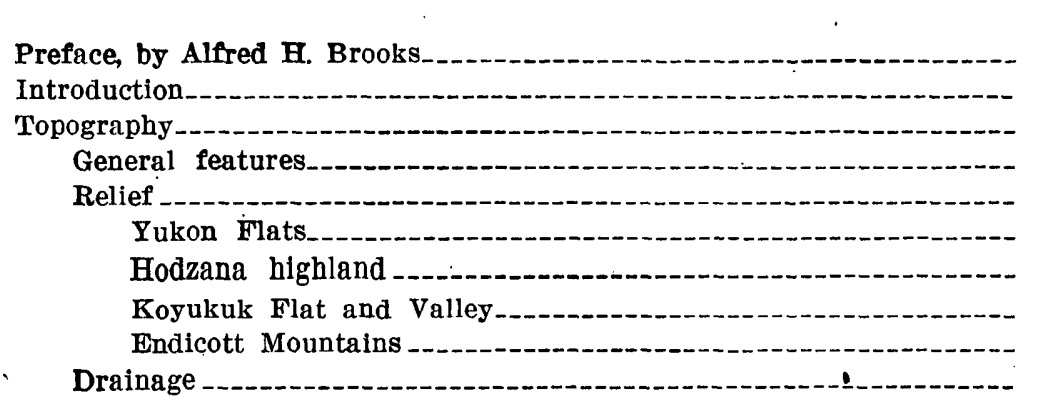

Page.

Streams flowing southward to the Yukon___._._- 15

General features-..-_-_-_- 15

Chandalar River and tributaries_-_- $\quad 16$

Orenzik, Hodzana, and Dall rivers_-_-_._- 21

Koyukuk drainage basin

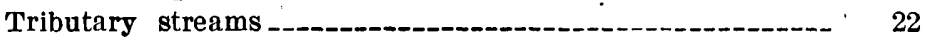

Kanut River -

South Fork of the Koyukuk and tributaries___________-_ 23

Middle Fork of the Koyukuk and tributaries_._._._._._._. 26

Climate -.- 27

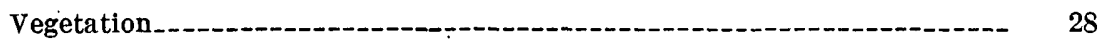

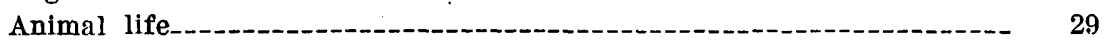

Population and settlements_._- 29

Transportation and trails_-_-_-_- 30

Geology -

Principal features.-_-_-_- 32

Geologic map -.- 33

General section -

Birch Creek schist (pre-Ordovician?) -

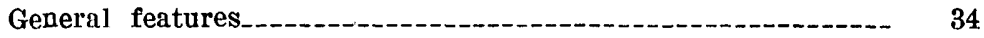

Lithology, distribution, and structure

Dall River area_.............. 36

Koyukuk-Chandalar area_-_..._-_._. 38

General features_-_-_-_._- 38

"Rapids" schist__._- 39

Amphibolite [hornblende] schist_-_-_-_._-_-_-_-.- 40

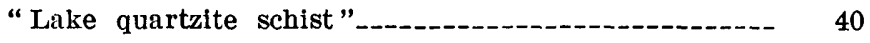

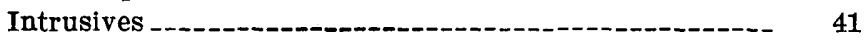

John River area.-_-

Totsen "series"-

Character and occurrence-_-_-_- 44

Structure-_-_.-- 44

Age and correlation 
Geology-Continued.

Birch Creek schist (pre-Ordovician?)-Continued. Page.

Summary

Correlation _.

Structure

Mineralization _._-_._. 47

Paleozoic rocks

Subdivisions__._._.

Devonian (?) rocks._._._._. 50

Character and distribution

Age and correlation

Carboniferous (?) rocks_____

Lithology, structure, and distribution

Age and correlation._._. 52

Mesozoic rocks _._-_._- 53

General features_-___._- 53

Cretaceous system

Character, structure, and distribution

Age and correlation

Mesozoic (?) intrusive rocks____._-_._._.

Cenozoic rocks _.-_-_-

Tertiary system

Cenozoic lavas (Tertiary or Quaternary) -

Quaternary system.-. 58

Pleistocene series _.....- 58

Sediments _........ 53

Glaciation _..-_- 60

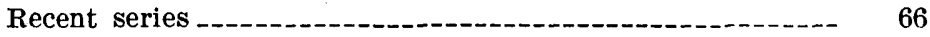

Mining -.-.-_- 68

Production -....-. 68

Methods of mining

Surface mining -

Underground mining -_._- 71

Costs and wages.-_- 72

Economic geology _._.

Géneral conditions -

Historical outline _.............. 76

Distribution and geologic association of gold

Classes of placers_-_-_-_-_-_-_-_-_- 78

Criteria for classification._._.

Present stream placers

Bench placers

Unconsolidated formations _._._- 80

Summary of classification

Source of placer gold

The placers . . . .

Koyukuk district

Drainage basins .

Middle Fork of Koyukuk River-_-_ 84

Tramway Bar and Chapman Creek_._-_._-_._._-_. 84

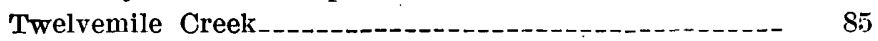

Rose Creek -

Porcupine Creek -.- 86

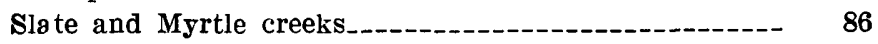


Economic geology-Continned.

The placers-Continued.

Koyukuk district-Continued.

Middle Fork of Koyukuk River-Continued. Page.

Clara Gulch -...-...- 89

Kelly Gulch

Marion Creek

Emma Creek_......... 90

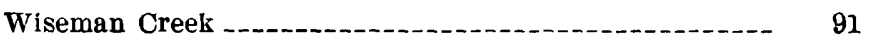

Nolan Creek and tributaries_._._._._. 92

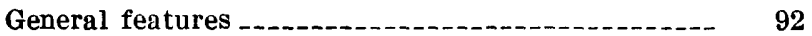

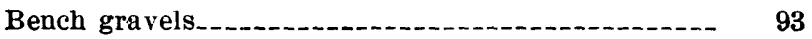

Shallow gulch gravels_.......... 93

Deep frozen gravels............................... 83

Character of gold

Minnie Creek _..._-

Union Gulch

Hammond Creek _-

Goldbottom, Swift, and Buckeye gulches_.........- 96

Vermont Creek

Streams between Hammond Creek and Gold Creek...... 99

Gold Creek

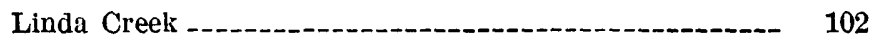

Bettles River and tributaries_..................... 104

South Fork of Koyukuk River-_._. 105

General features _._._._._._. 105

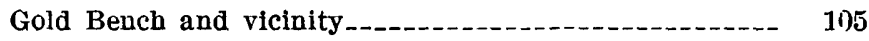

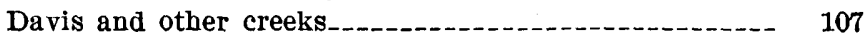

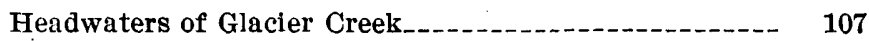

North Fork of Koyukuk River._._.

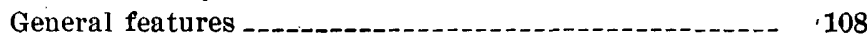

Mascot Creek_._._. 108

Wild River _._____ 109

John River ......... 110

Dall and Hodzana River region_..._.

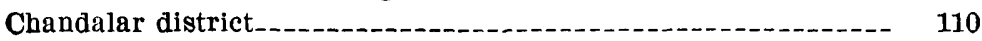

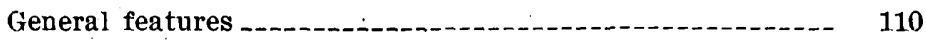

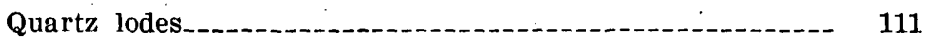

Placers _..._.

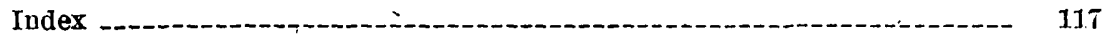




\section{ILLUSTRATIONS.}

Plate I. Topographic reconnaissance map of Koyukuk-Chandalar
region.age.
II. A, Hodzana highland, incised by upper valley of Hish Creek; $B$,
Mountainous portion of Hodzana highland between upper
forks of Bonanza Creek.....

III. $A$, Weathering and wind erosion of granite at head of Dall River; $B$, Flats on Middle Fork of Koyukuk River.......-. 14

IV. A, Endicott Mountains, in upper Dietrich River valley; $B$, Rapids on Chandalar River, 128 miles above mouth_-_-_-- 15

V. Geologic reconnaissance map of Koyukuk-Chandalar region_ In pocket.

VI. $A$, Limestone and schist contact in Endicott Mountains; $B$, Limestone cliffs south of Bettles River, a possible fault scarp_-_- $\quad \mathbf{3 4}$

VII. A, Pleistocene silt bluffs on Koyukuk River near Arctic Circle; $B$, Gold Creek valley near mouth

VIII. $A$, Horses towing freight scow, Middle Fork of Koyukuk River; $B$, Myrtle Creek valley_._._. 86

IX. A, Nolan Creek valley, showing principal mining plants; $B$, Nolan Creek valley, showing boiler house and dumps_-_-_---- 92

FIGURE 1. Map showing physiographic provinces of Koyukuk-Chandalar region

2. Sketch map showing distribution of timber in Koyukuk-Chandalar region -..........-. 


\section{PREFACE.}

By Alfred H. Brooks.

In 1899 F. C. Schrader and T. G. Gerdine carried a topographic and geologic reconnaissance survey through the Chandalar and Koyukuk basins, in northern Alaska. This was the first investigation of the mineral resources north of the Yukon. The time was well chosen, for it was in 1899 that the first important discoveries of placer gold were made in the Koyukuk district, though there had been some mining on the river bars during the previous decade. Since 1899 the Koyukuk has produced gold to the value of about $\$ 2,500,000$. Some promising gold-bearing veins have also been found in the Chandalar region.

As this progress in mining gave promise of yielding much new information about the occurrence of mineral deposits, and as Schrader's report had long been out of print, a second investigation of this field seemed justified. This resurvey was made by A. G. Maddren in the course of a single field season, during which he visited practically all the important localities of mining and also considerably extended the areal surveys. Mr. Maddren had the benefit of the geologic results achieved since 1899 in other parts of the Yukon basin, which have helped to elucidate a number of the stratigraphic problems. Although Mr. Maddren's conclusions as regards the geologic sequence differ somewhat from those reached by his predecessor in this field, yet this volume must in a measure be regarded as a revised edition of Schrader's report, which has proved remarkably accurate considering the conditions under which the field investigations were carried out.

Other systematic surveys have recently been made in northern Alaska. In 1911 and $1912 \mathrm{Mr}$. Maddren carried a geologic survey northward from Porcupine River to the Arctic Ocean, along the international boundary (one huridred and forty-first meridian, west longitude). In 1910 and 1911 P. S. Smith made reconnaissance surveys in the Kobuk and Noatak region, and the results of his work are embodied in a report ${ }^{1}$ now in preparation, which will include a

\footnotetext{
Smith, P. S., The Noatak-Kobuk reglon, Alaska : Bull. U. S. Geol. Survey No. 536.
} 
geologic map of an area that extends eastward to the western boundary of the area mapped in the present volume ( $\mathrm{Pl} . \mathrm{V}$, in pocket). These two maps will serve to elucidate the general geologic features of this northern region.

The geology of the northern part of this region has also been investigated. In 1901 F. C. Schrader and W. J. Peters (see p. 10) carried a geologic and topographic survey across the Endicott Mountains from the Koyukuk basin to the Arctic Ocean at the mouth of Colville River. The Arctic slope, east of the Colville, has been under investigation by $\mathrm{E}$. de $\mathrm{K}$. Leffingwell under private auspices since 1906. All these investigations will throw a flood of light on the geology of this most inaccessible part of Alaska. 


\title{
THE KOYUKUK-CHANDALAR REGION, ALASKA.
}

\author{
By A. G. Maddren. \\ INTRODUCTION.
}

The Koyukuk-Chandalar region, as here defined, includes the drainage basins of upper Koyukuk River and of Chandalar River, both tributary to the Yukon from the north. It is blocked out by the Arctic Circle and the sixty-eighth parallel of north latitude and the one hundred and forty-sixth and one hundred and fifty-fourth meridians of west longitude (Pl. I, in pocket). The special purpose of this report, however, is to describe that part of this region in which gold placers have been developed. A general account of the geography and geology of the whole region, so far as the data at hand warrant it, will first be presented to serve as an introduction to the more detailed statements in regard to the Chandalar and Koyukuk placer districts. These districts lie well within the southern ranges of the mountain system that forms the Yukon-Arctic divide across northern Alaska and are noteworthy as constituting one of the most northerly gold-mining regions in the world.

The information at hand has been gathered by members of four different Geological Survey expeditions following routes essentially different though coinciding to a certain extent. The first party to survey any portion of this field was led by F. C. Schrader, ${ }^{1}$ who traveled from Fort Yukon up Chandalar River to the headwaters of its chief branch, portaged across the mountains to Robert Creek, the principal source of Bettles River, descended that stream, and ascended Dietrich River, then returned to the mouth of Bettles River and descended the Middle Fork of the Koyukuk and the main Koyukuk to Nulato, on the Yukon. T. G. Gerdine made a topographic reconnaissance map of this route, and a detachment from the main party, under D. C. Witherspoon, portaged from Slate Creek to the South Fork of the Koyukuk and followed the lower half of that river, carrying a survey over the route traversed. During the sum-

1 Schrader, F. C., Preliminary report on a reconnalssance along the Chandlar and Koyukuk rivers, Alaska, in 1899 : Twenty-first Ann. Rept. U. S. Geol. Survey, -pt. 2, 1906, pp. 441-486. 
mer of 1901 Schrader ${ }^{1}$ again made geologic observations with another exploratory expedition which ascended John River, a large northern tributary of the Koyukuk west of the Middle Fork, crossed the Arctic divide, and descended Anaktuvuk and Colville rivers to the Arctic coast. W. J. Peters, topographer, carried a reconnaissance survey along this route. In the same year a party in charge of W. C. Mendenhall ${ }^{2}$ and D. L. Reaburn made similar geologic and topographic surveys from Fort Hamlin, on the Yukon, up Dall River, down the Kanuti to the Koyukuk, up the Alatna, and down the Kobuk to Kotzebue Sound.

All three of these parties traveled with canoes along the larger streams, so that their observations were necessarily confined to the valleys and immediately adjacent regions. In the present account free use has been made of the results of these expeditions to supplement those obtained by the writer. A fourth expedition entered this region during the summer of 1909 , when the writer with one man and a pack horse traveled overland from Fort Hamlin to the upper part of Dall River, thence northward over the western ridges and slopes of the mountains that form the divide between the eastern tributaries of the Koyukuk and Hodzana River, across Mosquito and South Forks, through Sitkum Pass and down Slate Creek to the settlement of Coldfoot, at its mouth, on the Middle Fork of the Koyukuk. After spending the month of August visiting the principal placer-mining localities tributary to the Middle Fork as far north as Gold Creek and gathering information about the occurrence, distribution, and general development of the gold placers of the Koyukuk district, the party made a hasty visit to the Chandalar district, to the east, early in September, whence it returned to Fort Yukon by way of Chandalar River. The results of this work, so far as it related to the gold placers, have already been published. ${ }^{8}$

As there was no base map of the region lying between the Yukon and Coldfoot along the route traveled, the writer carried a rough plane-table survey across this area, to connect the previous work of Gerdine and Reaburn. The results of this survey, together with valuable information furnished by prospectors met in the course of the journey, have been incorporated with all other available topographic data at hand in the accompanying map (PI. I, in pocket). This map is printed on the scale of $1: 500,000$, or approximately 8 miles to the inch, with 500-foot contours. It is based largely on the surveys made by Gerdine and Witherspoon during the expedition of

1 Schrader, F. C., A reconnalssance in northern Alaska: U. S. Geol. Survey Prof. Paper No. 20, 1904.

Mendenhall, W. C., Reconnaissance from Fort Hamlin to Kotzebue Sound, Alaska : U. S. Geol. Survey Prof. Paper No. 10, 1902.

3 Maddren, A. G., The Koyukuk-Chandalar gold region : Ball. U. S. Geol. Survey No. 442 1910, pp. 284-315. 
1899, with additions from the portions covered by Peters and Reaburn in 1901 and by the writer in 1909, and from information furnished by prospectors about areas that have not been visited by Geological Survey parties. Although far from being accurate throughout, this map at least has the merit of bringing together in graphic form the most reliable information available in regard to the larger topographic features of the region.

As regards the account of the geology here presented, the obligation of the writer to the work of. Schrader and Mendenhall, who covered considerable portions of the area here mapped, will be evident to all who refer to their reports on this region.

\section{TOPOGRAPHY.}

\section{GENERAL FEATURES.}

The Koyukuk-Chandalar region falls within two of the larger physiographic provinces of Alaska. Its northern third lies within the Endicott Mountains, which are usually considered a part of the northwestern extension of the Rocky Mountain system. The rest of the province, comprising two extensive lowlands and a highland area, which includes some mountains, lies within what has usually been termed the central plateau. It should be stated, however, that the dissected-plateau type of topography is hardly characteristic of the entire region here under discussion, but for convenience of description the term now in the literature will be retained.

This region can further be subdivided into four topographic subprovinces-(1) the Yukon Flats, (2) the highland lying between the Chandalar and the Koyukuk, much of which is drained to the south by Dall and Hodzana rivers and which will be called the Hodzana highland, (3) the Koyukuk Flat and Valley, and (4) the Endicott Mountains. (See fig. 1.)

The southern part of the region is drained southward through Chandalar and other rivers which are directly tributary to the Yukon, and the northern part southwestward through streams that are tributary to Koyukuk River. The Koyukuk, in turn, joins the Yukon about 200 miles southwest of the area here under discussion.

\section{RELIEF.}

\section{YUKON FLATS.}

The southeastern part of the region here described is a part of the extensive basin lowland known as the Yukon Flats. This feature of relief forms an expansion of the Yukon Valley floor, about 200 miles in length from east to west and 40 to 80 miles in width from north to south. Yukon River flows into this basin from the southeast 
out of a valley which, in marked contrast to the flats, is comparatively narrow and deep. Above the flats the valley floor is only from 1 to 4 miles wide, and its slopes rise steeply and in many places abruptly to uplands which stand from 1,500 to 3,000 feet above the river. After trâversing the Yukon Flats for about 100 miles in a northwesterly direction the river near Fort Yukon makes a bend to the southwest and here is joined by the large Porcupine River from the northeast. It then flows southwestward for about 190 miles by its winding course, or approximately 120 miles by direct distance, and near Fort Hamlin it leaves the flats by a narrow valley. This, like the valley above the flats, is deeply trenched into an upland.

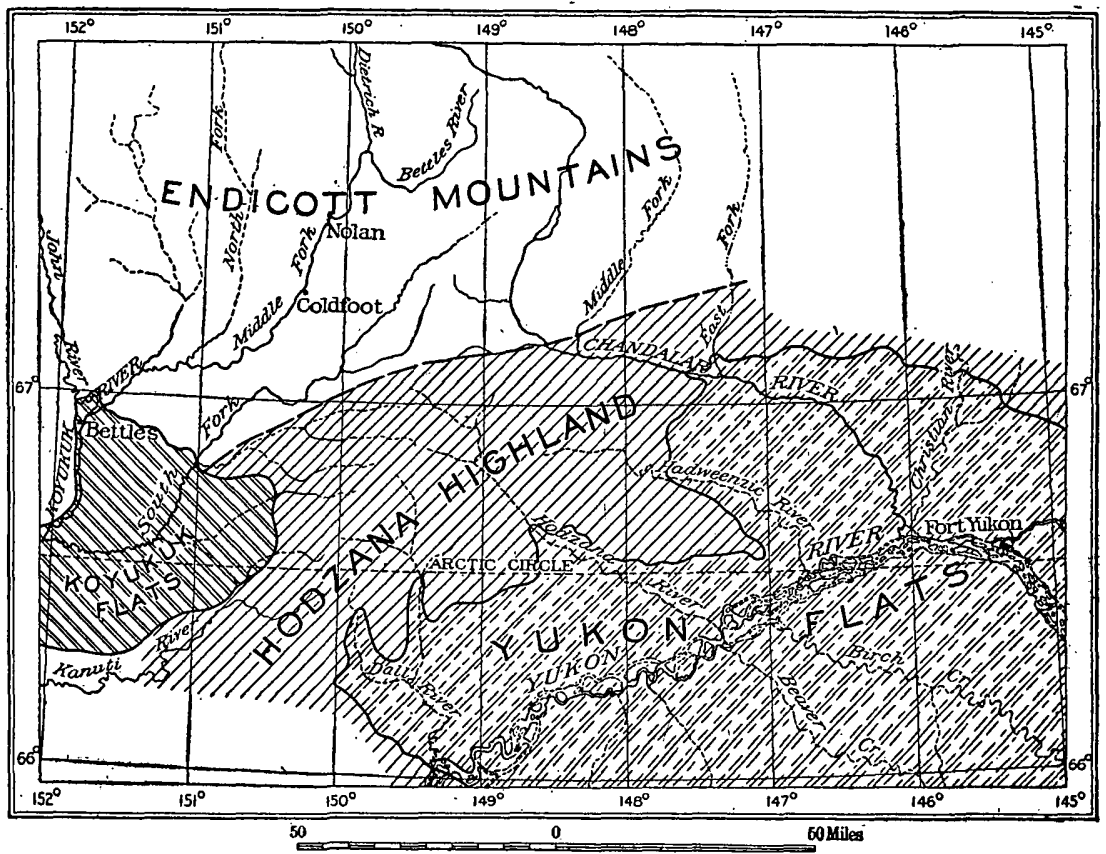

Figure 1.-Map showing physiographic provinces of Koyukuk-Chandalar region.

An encircling rim of uplands of varying relief entirely surrounds the Yukon Flats basin, broken only by the upper and lower Yukon Valley as described above and by the valleys of two large tributary streams, Porcupine and Chandalar rivers. These valleys have been clearly incised to their present depth across the upland rim by these streams within a comparatively recent period. In many places gentle slopes rise from the floor of the basin to the higher level of the upland, but here and there the transition is more abrupt, the upland presenting a steep escarpment to the lowland. The Yukon within the flats spreads out broadly and divides into numerous channels that diverge and reunite in a confusing manner about many large and 


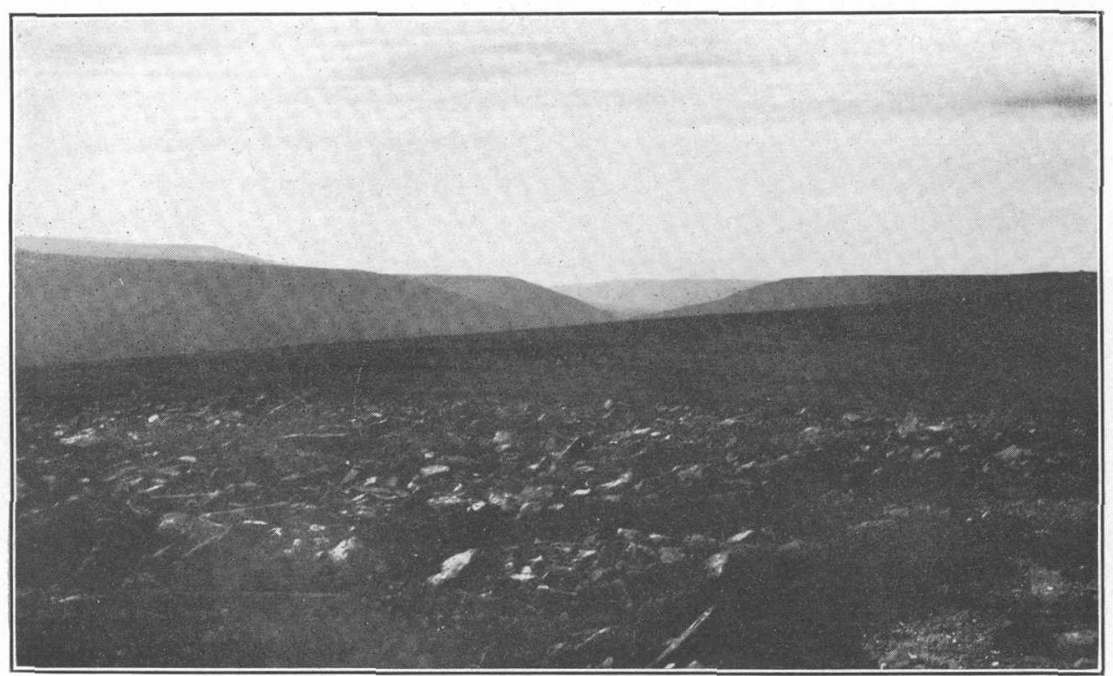

A. HODZANA HIGHLAND, INCISED BY UPPER VALLEY OF FISH CREEK.

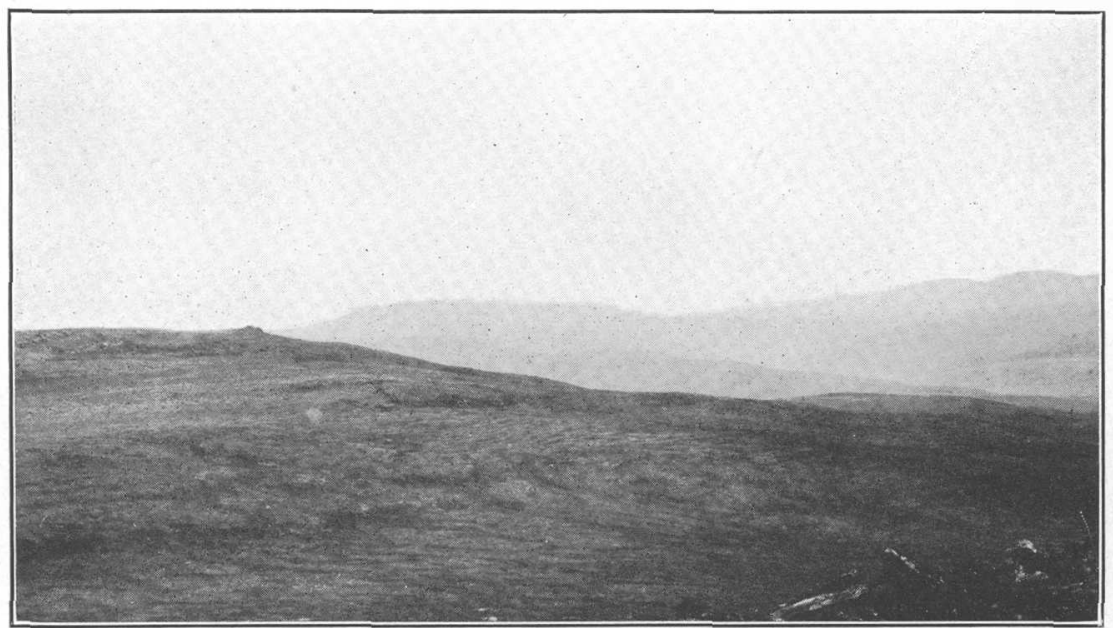

B. MOUNTAINOUS PORTION OF HODZANA HIGHLAND.

Looking south between upper forks of Bonanza Creek. 
small islands and bars. This meandering network of channels has in places a width of about 10 miles. The larger islands stand from 8 to 12 feet above the usual river level and are generally thickly timbered with spruce. The lower islands and the bars are more or less covered by the river during flood stages each summer. Where exposed to the rapid currents the banks and bars are being continually eroded away and shifted, but some of them are permanent enough in position to become more or less covered with a good growth of willows. The real banks of the river are usually a few feet higher than the islands. They stand from 15 to 25 feet above the usual river level.

The casual traveler who passes through the Yukon Flats gains the impression that they are actually level. This impression is not quite correct, for the Yukon flows through this basin from east to west for a distance of more than 200 miles with an average current of about 4 miles an hour, and it is evident that the bed of the river has con. siderable downstream grade. Mendenhall ${ }^{1}$ estimates the slope of the Yukon between Fort Yukon and Fort Hamlin to be about 0.9 foot to the mile. Using this estimate, in the absence of definite surveys, as a basis for making an approximate calculation of the grade of the Yukon Flats, we find that the present general surface is about 200 feet higher at the east end of the basin than at the west end.

\section{HODZANA HIGHLAND.}

The Hodzana highland embraces a rather ill-defined area bounded on the south and east by the Yukon Flats, on the west by the Koyukuk Flats, and on the north by a broad depression which separates it from the foothills of the Endicott Mountains. This province forms a belt from 40 to 50 miles wide which extends in a northeast-southwest direction in accordance with the trend of the major bedrock structure. The highland is characterized by even-topped ridges from 2,000 to 3,000 feet above sea level (Pl. II, $A$ ), which have moderately undulating profiles and rounded contours, and above which rise comparatively rugged isolated mountain masses and peaks whose summits stand from 4,000 to 5,000 feet above the sea (Pl. II, $B$ ).

This highland area is broken into a number of irregularly outlined masses by broad valleys. Some of the mountain masses and peaks which stand above the general level have sufficiently well-defined trends to be classed as minor ranges, and these have received various names, such as the Yukon and Romanzoff mountains. The trend of these ranges is determined by structural features. Their preservation at higher altitudes is probably due to the fact that their constituent

${ }^{1}$ Mendenhall, W. C., Reconnaissance from Fort Hamlin to Kotzebue Sound, Alaska : Prof. Paper U. S. Geol. Survey No. 10, 1902, p. 19. 
strata are more resistant to weathering than the surrounding rocks. They may, however, be due in part to accidents of erosion. The best defined of these higher masses forms the watershed between the Koyukuk on the west and northwest and the southeastward drainage of the Dall and Hodzana into the Yukon. The general height of this divide is between 3,000 and 3,500 feet above sea level, but some peaks along its crest attain 4,500 to 5,000 feet. The passes along the crest of these mountains range from 1,500 to 3,000 feet above sea level. Some of the mountains along the divide present smooth, rounded profiles; others are much more rugged in form. The rugged forms appear to be caused by the presence of large masses of hard igneous, mainly granitic rocks, dikelike masses of which present serrated forms that stand up prominently on ridges that are otherwise comparatively smooth (Pl. III, $A$ ).

The depression which bounds the highland area on the north is essentially a broad flat trough bounded for the most part by strong mountain slopes, which trend in an east-west direction. It is about 10 or 15 miles in width and extends from the Koyukuk Valley lowlands on the west to the Chandalar Valley on the east. Its eastward drainage is carried by tributaries of the Chandalar, West Fork, and Crooked Creek, and its westward drainage by the upper South Fork of the Koyukuk and its principal tributary, Mosquito Creek. The divides between these streams are flat and gravel covered, and broad flat-topped ridges at a little higher elevation occupy the interstream areas.

KOYUKUK FLAT AND VALLEY.

The Koyukuk Flat is a broad basin lowland which occupies the southwestern part of the area under discussion. It is bounded on the east and south by the gentle slopes of the Hodzana highland, already described, and on the north by the foothills of the Endicott Mountains (PI. III, $B$ ). The bordering slopes in places rise gently or by a series of alluvial terraces. At the mouths of the tributary streams the lowland floor extends up the bottoms of the valleys within the mountains. The lowland is very irregular in outline but is approximately 50 miles square.

This lowland is drained to the southwest, beyond the region here described, by Koyukuk River. The main river hugs the northwest side of the basin and leaves it through a comparatively narrow valley entrenched into a highland which forms its rim in this direction. This valley is comparable in a general way with that of the Yukon below the Yukon Flats, but differs in not being so deeply cut.

Several tributaries of the Koyukuk meander across this lowland in tortuous courses, and oxbow lakes are not uncommon. The entire floor of the basin is covered with alluvial deposits and resembles the 


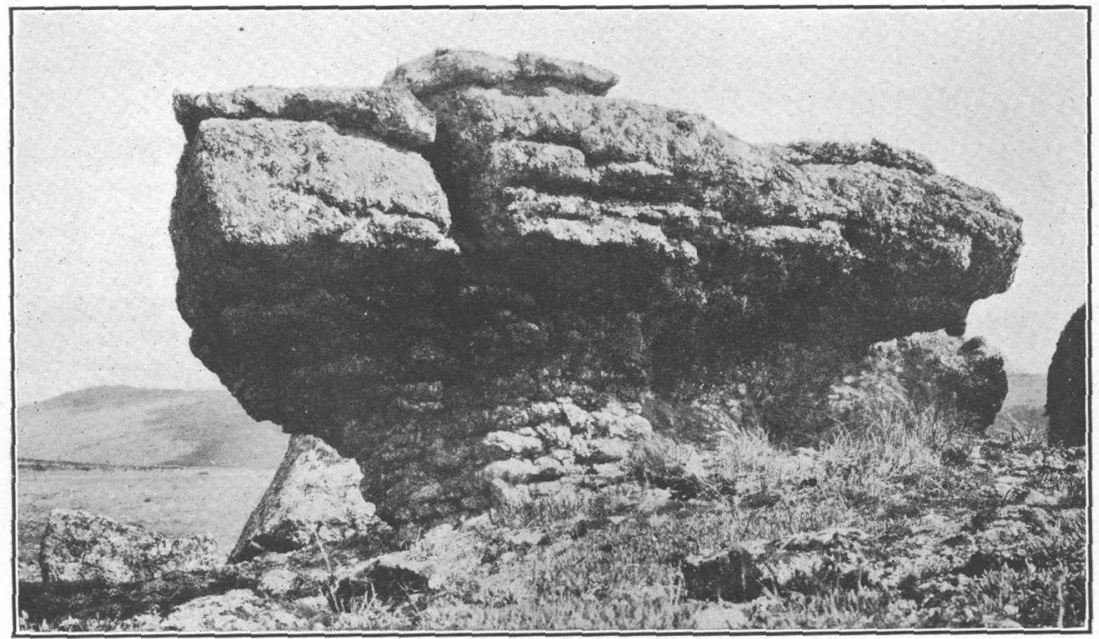

A. WEATHERING AND WIND EROSION OF GRANITE AT HEAD OF DALL RIVER,

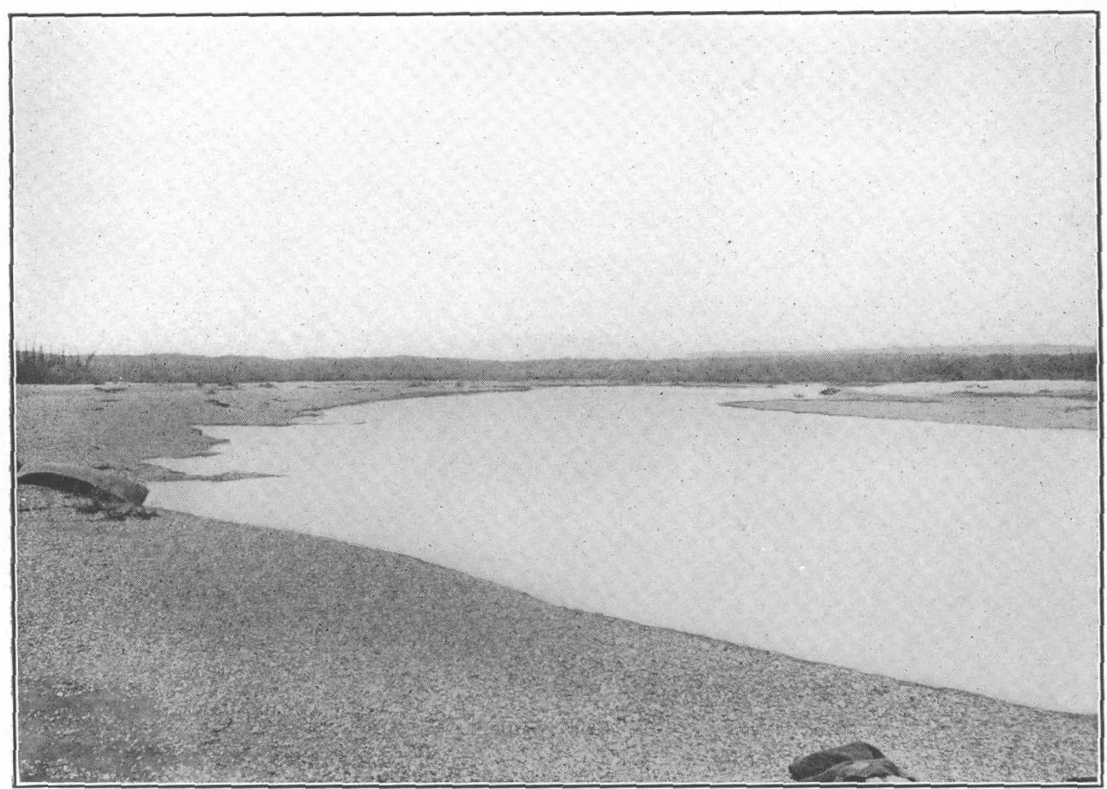

B. FLATS ON MIDDLE FORK OF KOYUKUK RIVER. 


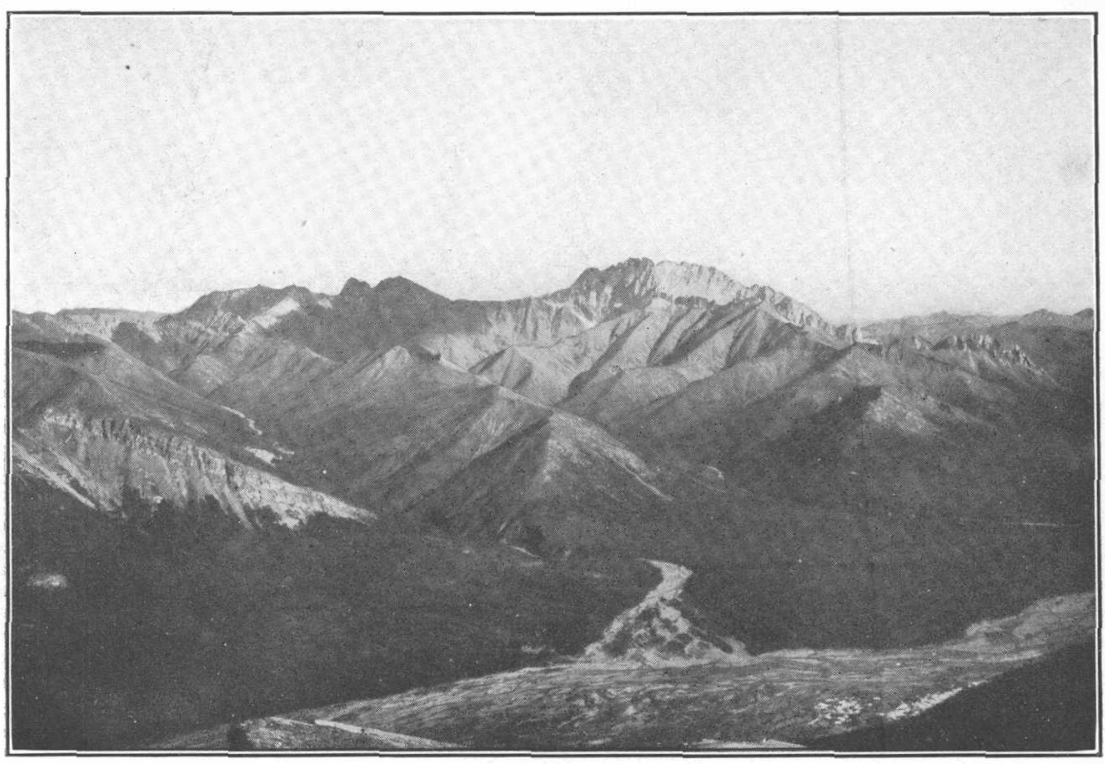

A. ENDICOTT MOUNTAINS, IN UPPER DIETRICH RIVER VALLEY.

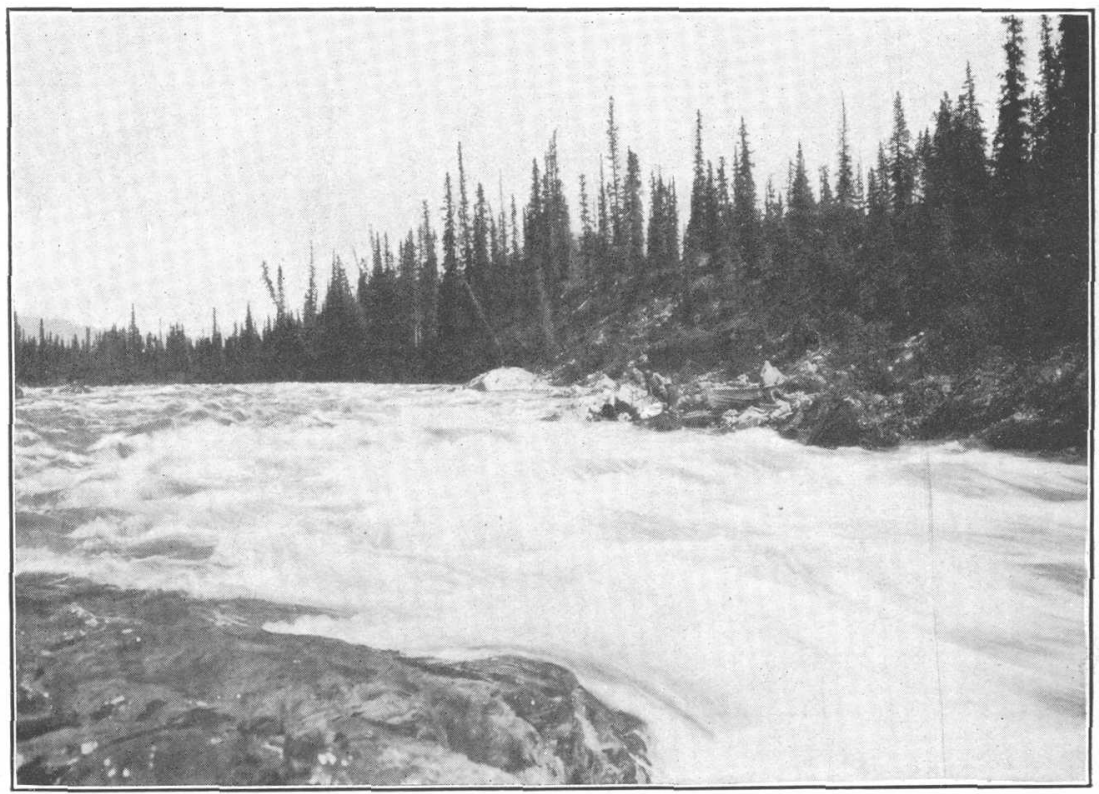

B. RAPIDS ON CHANDALAR RIVER, 128 MILES ABOVE MOUTH. 
Yukon Flats, with which it has been compared by Schrader. Mendenhall has noted the southern extension of this broad basin along the lower Kanuti River from 30 to 60 miles above its mouth.

\section{ENDICOTT MOUNTAINS.}

That part of the region lying north of latitude $67^{\circ}$ lies chiefly within the belt of rough topography which has been called the Endicott Mountains (Pl. IV,$A$ ). These mountains embrace a rugged mass whose crest line is north of the region here described. They are, however, a part of the mountain system which stretches for more than 400 miles westward from the international boundary (141st meridian, west longitude) and forms the watershed between the Yukon drainage on the south and the streams that discharge into the Arctic Ocean on the north. In their widest place the mountains are about 80 miles in width. They are broken by broad passes and dissected by many valleys, which have been deeply glaciated. On the north they fall off abruptly to a region of less relief, the broad interstream areas of which form the Anaktuvuk Plateau, but on the south they descend to the Koyukuk and Chandalar valleys through a series of deeply dissected foothills. The highest peaks vary in altitude from 7,000 to 9,000 feet, but the average altitude of the crest line is only about 6,000 feet above the sea. Schrader has noted what appeared to him to be a rather striking accordance of summit level throughout these mountains, but this interpretation is not concurrent with the opinion of the writer. They appear rather a deeply dissected, broad mountainous belt whose topography has been greatly influenced by glacial erosion. The part of the range included in the region here under discussion embraces a series of north-south interstream areas or spurs which are offshoots from the main range, with some isolated peaks of greater relief to the north and more or less detached groups of lower mountains or foothills along their southern border.

\section{DRAINAGE.}

\section{GTREAMS FLOWING SOUTHWARD TO THE YUKON.}

GENERAL FEATURES.

The general character of that part of Yukon River embraced within the area shown on the map (Pl. I, in pocket) has already been described. Four rivers of considerable size enter the Yukon from the northwest within the Yukon Flats. They are, in downstream order, the Chandalar, the largest, which joins the Yukon 24 miles below Fort Yukon; the Orenzik, about 25 miles below the Chandalar; the Hodzana, about the same distance below the Orenzik; and the Dall, at the west end of the Yukon Flats, 9 miles above Fort Hamlin. All 
these streams have similar features. They are more or less parallel, and, after flowing in courses which are upstream in direction as compared with the Yukon, make downstream or right-hand bends as they approach the main river. At their mouths are broad valleys whose floors merge with the Yukon Flats and which narrow upstream. The Chandalar presents some exceptional features, and for this reason and because its drainage basin is of greater present economic importance, it will be described at some length.

GHANDALAR RIVER AND TRIBUTARIES.

The Chandalar River basin drains nearly all the northeast quarter of the area shown on the map (Pl. I, in pocket). It differs from the other three rivers which flow into the Yukon Flats from the northwest in that it rises much farther to the north and northwest, on the Yukon-Arctic divide, in the part of the high and rugged Endicott Mountains which extends eastward from the headwaters of the Middle Fork of the Koyukuk. It has three headwater branches-the East, Middle, and North forks-all of which rise on this divide and flow southward in relatively narrow, deep valleys for about 75 miles in direct distance, through the southern ranges and across the general trend of the Endicott Mountains. The Chandalar has been ascended by small steamers as far as Chandalar station, about 70 miles from the mouth, or 5 miles above its junction with the East Fork.

The westernmost branch, which may properly be considered the upper part of the main river, but is locally called the North Fork by prospectors, is bounded on both its east and west sides by rugged mountains that rise boldly and in many places abruptly from its valley floor to heights of 2,000 to 4,000 feet above the river, or from 3,000 to 6,000 feet above sea level. Along the divide west of this valley some peaks rise to nearly 7,000 feet above sea level. The divides on either side of the North Fork do not lie more than 10 or 12 miles back from the river, so its valley is in few places more than 25 miles wide from one crest to the other. In consequence of this narrowness the lateral tributary drainage is carried mostly by short, swift streams that have steep gulch valleys. The North Fork valley may be considered to end at the southern edge of the Endicott Mountains, just above the point where Crooked Creek comes in from the west and the river turns southeastward. The floor of the North Fork valley is from 1 to 2 miles wide. On the whole it is a filled valley floor like those of all the larger valleys across the southern flanks of the Endicott Mountains, but it presents three features that distinguish it from most of the others. These features are (1) rapids caused by the outcrop of bedrock at the river level, about 7 miles above Crooked Creek (Pl. IV, $B)$; (2) a large lake 8 miles 
long by $1 \frac{1}{2}$ miles wide, which occupies nearly the entire width of the valley bottom and whose lower end is about 8 miles above the rapids; and (3) about 30 miles of silt flats above Chandalar Lake, through which the river flows with a slow current by a winding course. The lake and the silt flats above it are apparently closely related phases of a partly filled bedrock valley, which seems to be a long overdeepened trough whose lower 8 miles is now occupied by Chandalar Lake and whose upper 30 miles is filled by sediments. Chandalar Lake is approximately 2,000 feet above sea level. The character of the sedimentation appears to indicate that formerly the lake extended farther upstream and that it has been and is still being gradually filled at its upper end. Around its shores there are gravel and silt benches which indicate that its surface has been at least from 50 to 100 feet higher and that its lower end was farther down the valley toward the rapids, for the river between the lake and the rapids is now entrenched into silts and gravels in a way that shows that the surface of the lake has been lowered recently. Schrader ${ }^{1}$ has suggested that the bedrock basin of this lake is due to glacial erosion.

From the foot of the lake to the rapids, a distance of about 8 miles, the grade and current of the river are moderate. It meanders somewhat and cuts a few silt and gravel banks that stand from 15 to 30 feet high. It runs over some gravel and a few bowlder riffles, and as it approaches the rapids the bowlder riffles become more numerous. At the rapids hard quartzose mica schist crosses the bed of the channel and crops out along the banks (Pl. IV, $B$ ). Here the bowlders are very numerous, and they continue so to Crooked Creek and beyond around the big eastward bend for a distance of more than 25 miles. This portion of the river has a steeper grade than any other part of its course, and the channel is so thickly strewn with bowlders and cobbles that it is very rough. The current is swift, and there are numerous riffles caused by bowlder and cobble bars.

The Middle Fork of the Chandalar is from 15 to 20 miles east of and roughly parallel to the North Fork. The upper half of its valley is in the rugged divide section of the Endicott Mountains; the lower half is of more open form, and the bordering mountains are not so high as those to the north and west. This open part of the valley is filled with gravel deposits that lie along its sides as terraces or benches. The stream, which is of good size, flows with a moderately swift current through these deposits and in cutting its channel down into them has concentrated the bowlders, cobbles, and coarse gravels along its bed in a series of successive steplike

\footnotetext{
1 Schrader, F. C., Preliminary report on a reconnaissance along the Chandalar and Koyukuk rivers, Alaska, in 1899 : Twenty-first Ann. Rept. U. S. Geol. Survey, pt. 2, 1900, p. 465 .
}

$76032^{\circ}-$ Bull. $532-13-2$ 
fans over which the stream flows alternately by steep, short stretches with swift riffles, separated by flatter and longer stretches where the velocity of the current is moderate. In these slack stretches the stream generally flows over finer gravels, sands, and locally over silts. This steplike arrangement of the bars along the Middle Fork of the Chandalar does not seem to have any relation to the form of the bedrock floor of the valley, which is apparently covered to a considerable depth by the unconsolidated deposits, nor to a previous concentration of the coarser materials in the terrace deposits at positions corresponding to the bars along the present stream channel, for the cobbles and bowlders in the older deposits into which the present stream channel is cut do not appear to have localized distribution such as is shown by the bars along the present river bed. These unconsolidated bowlder-bearing benches may be of direct glacial deposition. 'They are at least of glacial origin to the extent of being outwash deposits.

Between the lower halves of the North and Middle forks of the Chandalar there are two parallel mountain ridges separated by a narrow north-south valley about 30 miles long that is drained by a good-sized stream named Big Creek. The principal gold-placer deposits of the Chandalar district are situated in the headwater gulches of this creek.

Just north of the high mountains at the head of Big Creek there is a very marked east-west depression that connects the valleys of the North and Middle forks. This depression opens into the North Fork valley about 6 miles above Chandalar Lake and joins the Middle Fork valley about 50 miles above its mouth. It is bounded on the north and south by mountains that rise abruptly 2,500 feet above its bottom. The floor of the depression is from 1 to $1 \frac{1}{2}$ miles wide and is covered and apparently filled to a considerable depth by unconsolidated glacial outwash deposits. On the surface of these deposits are a number of small shallow basins occupied by a chain of lakes which receive the lateral drainage of short streams from the mountains on either side. The waters of most of these lakes drain westward into the North Fork by way of Lake Creek, but several of the smaller easternmost ponds find an outlet to the east into Middle Fork by way of Grave Creek. Both Lake and Grave creeks have a fall of 300 or 400 feet in their lengths of 8 and 11 miles, respectively, and the lower halves of their courses are intrenched into the unconsolidated filling of the east-west trough which connects the valleys of North and Middle forks. The principal streams tributary to this valley trough on its south side are Big Squaw and Little Squaw creeks, flowing into Lake Creek, and McClellan Creek, flowing into Grave Creek. These creeks flow down deep gulches on the northern slopes of the mountains at the head of 
Big Creek. Similar deep gulches are eroded into the southern slopes of this same mountain group by headwater branches of Big and Tobin creeks. It is in these gulches on the north and south sides of this group that the placer gold of the Chandalar district occurs, and its source is in this mountain mass.

The East Fork of the Chandalar, which was not visited, appears to have a valley with the same features as that of the Middle Fork. The mountains between Middle and East forks are somewhat lower and less rugged in form than those between North and Middle forks. The mountains east of East Fork, separating it from Christian River, are also lower and more rounded in form, and toward the south gradually merge into the foothills on the north side of the Yukon Flats. The pronounced east-west valley trough occupied by Lake and Grave Creeks between North and Middle forks continues eastward from Grave Creek to the East Fork, across the mountains that separate these two large branches of the Chandalar. This portion of the trough is occupied by a chain of lakes of much larger size and at a lower level than those between the North and Middle forks.

The courses of the three headwater branches of the Chandalarthe North, Middle, and East forks - are all transverse to the general east-west trend of the Endicott Mountains. The valleys of these streams are comparatively narrow and deep, and bold mountains rise between them to heights from 2,000 to 5,000 feet above their floors. To the south these three valleys open out and join a wide east-west topographic depression that marks the southern border of the Endicott Mountains between Chandalar and Koyukuk rivers. This depression, which has already been described (see p. 14), extends westward from the northern edge of the Yukon Flats, a short distance below the mouth of the East Fork of the Chandalar, for about 75 miles across a wide, open divide to the South Fork of the Koyukuk; thence over another low, flat divide is 'Tramway Bar, on the Middle Fork of the Koyukuk; and down the Middle Fork valley to the mouth of John River, where it merges with the Koyukuk Flat.

The eastern half of this depression, which separates the Endicott Mountains on the north from the Hodzana Highland on the south, is now occupied by the main Chandalar River. The Chandalar may be considered to begin where the North Fork leaves the Endicott Mountains, is joined by Crooked Creek, and turns eastward. From this bend it flows in a direction a little south of east for about 60 miles, leaves the mountains, enters the Yukon Flats, and gradually swings more to the south before it flows into Yukon River about 24 miles below Fort Yukon.

Crooked Creek and West Fork are about 15 and 20 miles long; respectively. Their valleys are wide basins separated by a flat-topped 
ridge that stands about 3,000 feet above sea level. From Crooked Creek to the Yukon Flats, a distance of about 60 miles, the Chandalar Valley has a wide, open form and its bordering mountains have comparatively moderate slopes. All the large tributaries of this section of the valley come from the north. Those from the south, which rise opposite the headwaters of the Hodzana and Orenzik, are all small and short, none being over 10 miles long. The bottom of the valley is from 5 to 7 miles wide and is filled with unconsolidated sediments that appear to be glacial outwash deposits of silts, gravels, cobbles, and a considerable number of large bowlders. These deposits are spread across the whole width of the valley and extend along its whole length. They grade without any change in character into the similar deposits that fill the large tributary valleys from the north, and they extend westward up West Fork and Crooked Creek valleys to their heads, 1,000 feet above the main Chandalar Valley, and across the wide divide into the Koyukuk drainage basin, throughout the larger valleys of which they are as widespread as in the Chandalar basin.

The thickness of this valley filling of poorly assorted silts, gravels, cobbles, and bowlders is not known. The present channel of the main Chandalar is more or less intrenched in these deposits, and runs over a bed of the coarser, more concentrated material, which is so distributed as to form numerous riffles of large cobbles and bowlders. Through most of this section the river flows near the base of the slopes of the mountains that bound the south side of the valley, along which it cuts banks 100 feet high in the unconsolidated deposits and here and there cuts bluffs in the hard country rocks, but at no place is it known to flow upon bare bedrock. Where the river swings to its north bank it rarely cuts banks more than 30 feet high, and all of these are in the unconsolidated deposits, which extend to the north for several miles before they reach the slopes of the mountains. It is not known how high up the mountain slopes the unconsolidated deposits extend, but to judge from the high terraces observed along the valley of the Middle Fork, a height of 500 feet above the river does not seem improbable. Many lakes and ponds occur in shallow basins scattered over the flat surface of the valley filling between the river and the mountains to the north.

The Chandalar leaves the mountains a few miles below the mouth of East Fork and flows for about 60 miles across the gradually descending surface of the Yukon Flats to the Yukon. The fall of the river in this distance is about 400 feet, and its current through the upper half of this section is fairly swift, the grade of the stream bed being about 10 feet to the mile, but the fall gradually becomes less as the river approaches the Yukon, probably decreasing to 4 or 5 feet to the mile: In this part of the channel also there are numerous 
riffles caused by fan-shaped bars, but the gravels of these bars are smaller and better assorted than are those of the riffles farther upstream, within the mountains. The river is commonly divided by islands and bars into several channels. It cuts banks of light-colored silts from 30 to 100 feet high as it leaves the mountains, but these gradually decrease to heights of 10 to 20 feet and become darkercolored, like the typical alluvium of the lower. banks along the Yukon, and the whole country presents the flat, featureless appearance characteristic of the Yukon Flats. While this appearance is that of a level country, it is evident from the grade of the river that these unconsolidated deposits gradually slope from the northern border of the Yukon Flats to the Yukon, with a fall of at least 400 or 500 feet. At the edge of the flats they merge imperceptibly with the coarser unconsolidated filling of the Chandalar Valley, the surface of which at the mouth of the valley stands at about 1,200 feet above sea level, an elevation corresponding in general with that of similar benches of unconsolidated deposits that occur elsewhere about the borders of the Yukon Flats.

The Chandalar enters Yukon River by several diverging channels. About 7 miles from the Yukon a deep sluggish channel enters the river from the east, draining a chain of lakes and ponds, some of which lie only a few hundred feet fram the north bank of one of the Yukon channels. There is an easy portage across this short distance from one of the ponds to the Yukon that is used by the natives and prospectors who travel from the Chandalar to Fort Yukon. Christian River, a streâm of considerable length, empties into this sluggish channel a few miles east of the Chandalar. It rises in the mountains north of the flats to the east of East Fork and drains a large part of both the mountainous and the flat country between the Chandalar and the Porcupine.

ORENZIK, HODZANA, AND DALL RIVERS.

The basins of Orenzik and Hodzana rivers have not been visited by any of the Geological Survey parties. The representation of. their general location and extent on the accompanying map (Pl. I, in pocket) and the description of the country they drain have been compiled from sketches and notes furnished by prospectors.

Orenzik, Hodzana, and Dall rivers drain all the upland southeast of the divide that separates the Chandalar and Koyukuk basins on the north and west from the northwestern part of the Yukon Flats, which lies between Chandalar River and Fort Hamlin. The divide about the headwaters of these basins extends from east to west for about 60 miles between the Chandalar and the northern tributaries of the Orenzik and Hodzana, turns southwestward at the head of the Hodzana, and thence separates the western tributaries of the 
Hodzana and Dall from the drainage basins of the South Fork of the Koyukuk and the Kanuti. This divide is at no place more than 75 miles from the Yukon in direct distance, and Hodzana River, the largest of the three streams, is not more than 125 miles long.

The smaller valleys of all the headwater tributaries of these rivers appear to have rather steep grades, in places descending 1,000 feet within less than 10 miles. As a result, the streams are swift and have cut many deep gorges and some canyons along their upper courses. (See Pl. II, $A$, p. 12.) Even where several of these headwater streams have united to form larger branches and the valleys in general widen out with smooth-topped ridges between them, there are many contractions, caused by spurs of bedrock from the higher ridges through which the rivers have eroded gorgelike sections. Thus along these valleys within the mountains more or less widened or basinlike portions alternate with narrower gorgelike stretches. Many of these basin expansions have more or less flat bottoms, formed by fillings of unconsolidated gravels and finer sediments through which the streams in places meander widely with slackened currents. Through the gorges the channels are generally more direct, with swift currents and even with rapids. In other words, the valleys show considerable physical diversity along their courses through the mountainous Hodzana highland. The basins, like all similar topographic features in northern Alaska, whether high in the mountains or at lower levels, are covered with the usual tundra growth, are almost always swampy, and contain numerous lakelets and ponds.

The valleys of the Orenzik, Hodzana, and Dall all open out into the Yukon Flats in a manner similar to that of the Chandalar. The rivers meander back and forth across rather wide alluvial valley floors bounded on either side by the gradually lowering and receding ridges of the mountains that border the northwest side of the basin. The 'valley bottoms gradually expand and their filling intergrades with the similar deposits of the flats, over which the rivers flow in the lower 30 or 40 miles by very crooked courses. Over this country, which, like all the rest of the flats, is practically devoid of relief except for its gradually rising slope from the Yukon to the hills, are scattered a number of sloughs, ponds, and lakes, many of which appear to occupy parts of old and abandoned courses of the rivers or their tributaries.

\section{KOYUKUK DRAINAGE BASIN.}

TRIBUTARY STREAMS.

Koyukuk River is one of the largest tributaries of the Yukon and is about 700 miles in length from its mouth to the head of its Middle Fork. Within the region here discussed, the Koyukuk receives from the north and northwest five important tributaries that drain a large 
area of the southern slope of the Endicott Mountains. These are, from east to west, its Middle Fork or chief headwater branch, the North Fork, and Wild, John, and Alatna rivers. All but the extreme northern headwaters of the first four of these tributaries are shown on the map and will be described. Only a few miles of the lower course of the Alatna comes within the area mapped, so it will not be considered. There are also two large eastern branches of the Koyukuk-the South Fork and Kanuti River. The wide basin drained by all these rivers comprises the upper or northeastern half of the Koyukuk Valley, which is practically the area shown on the western half of the map (Pl. I, in pocket).

\section{KANUTI RIVER.}

Kanuti River was surveyed in 1901 by the Geological Survey party in charge of W. C. Mendenhall, ${ }^{1}$ who describes it as follows:

The Kanuti River is approximately 200 miles long. * * * It heads In the same mountains [Hodzana highland belt] whose northern slopes are drained by Fish Creek and Jim River, but within a few miles of its source [opposite the west branch of Dall River] it enters a relatively flat basin, 9 or 10 miles long and half as wide, which contains a number of small lakes and ponds although standing at an elevation of between 1,200 and 1,400 feet. This basin, like all similar topographic features in the North, whatever their relation to sea level, is a marsh, covered with the usual tundra growth. At its lower end, in longitude $150^{\circ} 45^{\prime}$ west, the river enters a restricted valley, so steeply walled in places as to deserve to be called a canyon, and having a maximum depth of 2,000 feet. The gorgelike character prevails for about 30 miles, and through much of this portion the river can scarcely be called navigable, since it is a succession of rapids, and the channel throughout is obstructed by bowlders of all sizes. Below this stretch the valley gradually broadens, and near the camp of July 12 [60 miles from the Koyukuk] is an extensive flat, which is perhaps n. part of the broad basin in which the lower portion of the South Fork of the Koyukuk flows.

Within this lower basin the Kanuti River receives a large tributary from the south in the direction of the sources of the Tozi [Tozitna] and Melozi [Melozitna].

About 25 miles above its mouth the river plunges into a second canyon about 10 miles long and 500 feet in depth. This is the most beautiful section of the river; the stream is swift but free from dangerous rapids, and the bluffs of slate and sandstone rise sheer from the water to a height of several hundred feet. Ten miles above the mouth it receives the waters of the Mentanontll, descended by Lieut. Allen in 1885 after his overland journey from the Yukon.

The hills which border this lower section of the Kanuti River and adjacent parts of the Koyukuk are seldom more than 1,500 feet in height, are not excessively steep, and are well timbered.

SOUTH FORK OF THE KOYUKUK AND TRIBUTARIER.

The South Fork of the Koyukuk is one of the largest and longest branches of that river. It rises about 10 miles west of Chandalar

1 Mendenball, W. C., A reconnaissance from Fort Hamlin to Kotzebae Bound, Alaska : Prof. Paper U. S. Geol. Survey No. 10, 1902, pp. 22-23. 
Lake, or just south of the headwaters of Bettles River, and flows southwestward about 175 miles to join the Koyukuk about 480 miles from the Yukon. At its confluence with the main river it is about two-thirds the size of the Koyukuk above that point. Its general course is parallel to that of the Middle Fork, which lies' northwest of it. The main ehannels of the Middle and South forks are nowhere more than 25 miles apart, and at one place a few miles below Tramway Bar on Middle Fork their main channels approach within 7 miles of each other.

The upper 20 miles of the South Fork valley lies within a rugged part of the southern Endicott Mountains just west of Chandalar Lake. The mountains forming the divide about its source stand over 6,000 feet above sea level, or about 4,000 feet above the valley bottom.

Below this headwater section the river flows through a flat basin area about 15 miles long and 5 miles broad that stands about 2,000 feet above sea level and is partly filled with gravels and silt. This basin is part of the pronounced east-west depression which extends from the Chandalar to the Koyukuk (see pp. 14, 19) and which separates the southern flank of the higher Endicott Mountains from the northern slopes and outlying ridges of the lower Hodzana Highland to the south. The river flows through this basin by a winding course, and on both sides of it there are a number of lakes and ponds scattered over the valley floor. At its northeast corner a broad gravel and silt ridge, whose wide, flat top is only a few hundred feet above the South Fork, or about 2,350 feet above sea level, passes over to the head of Crooked Creek, the tributary of the Chandalar that drains the northern part of the depression already described. The gravel and silt deposits of the basin are continuous with those along the valley of Crooked Creek. A similar but narrower gravel and silt divide passes from this basin westward to the valley of Slate Creek at approximately the same elevation $(2,350$ feet) as the divide to Crooked Creek, and the deposits of gravel and silt continue down the valley of Slate Creek to the Middle Fork of the Koyukuk. The stream that drains eastward into South Fork from the Slate Creek pass is named Bowlder Creek because of the continuous bed of bowlders it has concentrated from the unconsolidated deposits through which it has eroded its course.

The South Fork flows from the lower or southeast end of this basin by way of a mountain gorge about 7 miles long. The mountains on either side are about 3,500 feet high, or 2,000 feet above the river. Southeast of this mountain section the river again enters the Koyukuk-Chandalar depression, already described. Here the river has intrenched its channel to a depth of about 100 feet for about 5 miles directly southward across these unconsolidated deposits, 
beyond which it is joined by Mosquito Creek, a large tributary from the east.

Mosquito Creek has one of its two sources between South Fork and the head of Crooked Creek, in a shallow basin of the same unconsolidated sediments that are so widespread over this depression. Like most of these basins it contains a number of small lakes and ponds. This branch flows southward for about 10 miles through the basin and is then joined by another branch from the southeast which is opposite the West Fork of the Chandalar and whose sources drain a part of the northern portion of the Hodzana highland. The wide pass between the West Fork of the Chandalar and this branch of Mosquito Creek stands at a little more than 2,500 feet above sea level, and a mantle of unconsolidated water-washed sediments appears to extend across it from one basin to the other. From the junction of these two upper branches of Mosquito Creek the main stream flows southeastward for about 15 miles to join South Fork, as already noted. Throughout this distance it is intrenched to an average depth of at least 100 feet into the more or less assorted outwash deposits of gravel, bowlders, and silts that fill practically all the wide depression between the Chandalar and Koyukuk below the level of 2,500 feet. Between the South Fork and Mosquito Creek is a bench of these unconsolidated deposits whose flat surface rises gradually from an elevation of 1,500 feet along the South Fork to 2,000 feet at the southeast end of a narrow mountain ridge 5 miles to the northeast. There are several good-sized lakes on this bench toward the mountains. The narrow ridge extends northeastward for about 15 miles between the upper South Fork and Mosquito Creek basins. Several peaks on its southeast end rise to about 4,000 feet, but its height decreases toward the northeast to low knolls between 2,500 and 3,000 feet high that correspond in appearance and elevation to the similar knolls and wide flat ridges of bedrock between Crooked Creek and the West Fork of Chandalar River.

From the confluence of the South Fork and Mosquito Creek the enlarged river flows to the southwest between the northwestern front of the Hodzana highland and the southern margin of the un(:onsolidated deposits for a distance of about 25 miles, swinging to the northwest in the lower third of this section and then turning at right angles to the southeast again before flowing through another mountain-gorge section for 20 miles. The mountains of this section rise about 3,000 feet above sea level, or from 1,500 to 2,000 feet above the river.

After passing through this last group of mountains the South Fork is joined from the northeast by another large tributary named Jim River. From this point to its confluence with the main Koyu- 
kuk it flows with a crooked course for 65 miles through the flats. About halfway between Jim River and its mouth the South Fork is joined from the east by a third large tributary, Fish Creek.

All the large tributaries of South Fork enter it from the east, Jim River and Fish Creek being the largest. On the divide between these streams and Dall and Hodzana rivers the passes from one drainage basin to the other are from 2,500 to 3,500 feet above sea level. The headwater streams of all these rivers have eroded deep, narrow valleys to a depth of 500 feet or more, below the general level of the Hodzana highland. The interstream areas between Jim River and Fish Creek have the form of flat, even-topped ridges, which have the appearance of mesas (Pl. II, $A$, p. 12). To the north, however, Jim River drains an area of more rugged mountains, one of the groups which rise above the general level of the Hodzana highland (PI. II, $B$ ).

\section{MIDDLE FORK OF THE KOYUKUK AND TRIBUTARIES,}

The name Middle Fork is here used to designate that branch of the Koyukuk which is formed by the confluence of Dietrich and Bettles rivers and flows southward and westward about 75 miles to the point where it is joined by the North Fork 37 miles below Coldfoot. Middle Fork is the largest headwater tributary of the Koyukuk, and if Dietrich River is considered the principal source of the Koyukuk, it is in reality the main river. Like the North Fork of the Chandalar, the Middle Fork of the Koyukuk has its source on the Arctic divide far back in the Endicott Mountains, through which it flows southward by way of a deep valley that has a gravel-filled floor from 1 to 2 miles wide with rather abrupt mountain slopes on either side rising to an average height of 3,000 feet above the river. Its gradient is rather uniform, being about 20 feet to the mile from a point far up Dietrich River to Coldfoot, at the mouth of Slate Creek, where the narrow mountain valley widens out and its gravel flood-plain coalesces with the widespread sheet of outwash gravel deposits that are a continuation of those extending from South Fork. Although the Middle Fork runs on bedrock for a short distance at the mouth of Gold Creek, and perhaps at other points above this place, it has no rapids. Its current, however, is strong throughout its course in the Endicott Mountains and it flows over many cobble bars in swift riffles.

As many of the details of the drainage basin of that part of Middle Fork which lies within the Endicott Mountains will be considered in connection with the discussion of the gold-bearing placer deposits (pp. 84-105), it is not necessary to give further attention to this subject here.

From the southern edge of the Endicott Mountains just north of Slate Creek the Middle Fork flows through a region of lower relief, 
whose topography is varied by low mountains, wide, flat, gently sloping ridges, and a few areas of basin lowlands. The river turns more to the southwest and flows for about 65 miles through this section of lower relief to John River. Along the lower half of this section the channel is near the northern slopes of a group of mountains that lie between it and the South Fork, or along the southern margin of the gravel outwash fill that extends with an average width of 5 miles from Tramway Bar to the mouth of John River. This outwash deposit is apparently in large part a continuation of the similar deposits that are so widespread between Tramway Bar and South Fork. From John River the Koyukuk turns southward and skirts the low slopes of mountains that lie along its west side to its confluence with the South Fork, a distance of 35 miles. Throughout this north-south part of its course silt flats, 20 miles wide, extend between it and South Fork on the east. The basin occupied by these silt deposits has already been described.

\section{CLIMATE.}

The winters in the Koyukuk-Chandalar region are long and severe, the temperature being below zero most of the time. Temperatures of $-70^{\circ}$ have been reported. The average temperature for the three winter months is about $-15^{\circ} \mathrm{F}$. and for the three summer months about $55^{\circ} \mathrm{F}$. The summers, lasting from about the end of May until the middle of September, are characterized by clear weather with only occasional light showers. Brief records indicate that the total annual precipitation on the Koyukuk is between 11 and 12 inches. It is probable that the precipitation within the high ranges is somewhat greater, but there are no records to substantiate this supposition.

The principal supply of water in this region used in placer mining is derived from snow, but a moderate rainfall during the summer also adds a variable and uncertain amount to the total stream flow. The snowfall over this region is not great in average amount, and it is only the great length of the winter season, from October to April, that enables an average depth of 3 to 4 feet of it to accumulate. Most of the snow melts and passes away during May, when the streams are at their maximum flood stage. The larger streams continue to flow strongly during most of June, after which there is a subsidence with spasmodic increases until colder weather in September changes the precipitation into snow, freezes the higher mountain slopes, and lessens the flow. Early in October the rivers become frozen over, and although there is still some flow of water in all the larger valleys, as is made manifest by frequent outbursts from under the ice, these rarely do more than form temporary local accumulations of ice, which disappear the following May. Sometimes, however, these overflows of water from beneath the ice continue throughout the winter and form considerable masses of flood-plain ice, called 
"glaciers" by the miners, which are not entirely removed during the following short summer and become somewhat permanent features.

The rugged topography of this region presents many high, cold sheltered slopes and mountain-surrounded basins in which a considerable part of the snowfall does not melt rapidly, so there is generally a reserve flow of water in all the larger streams throughout the summer, but on the smaller creeks water sometimes becomes too scanty for the effective handling of the gold-bearing gravels, and the miners must depend on uncertain rainfalls, especially during August.

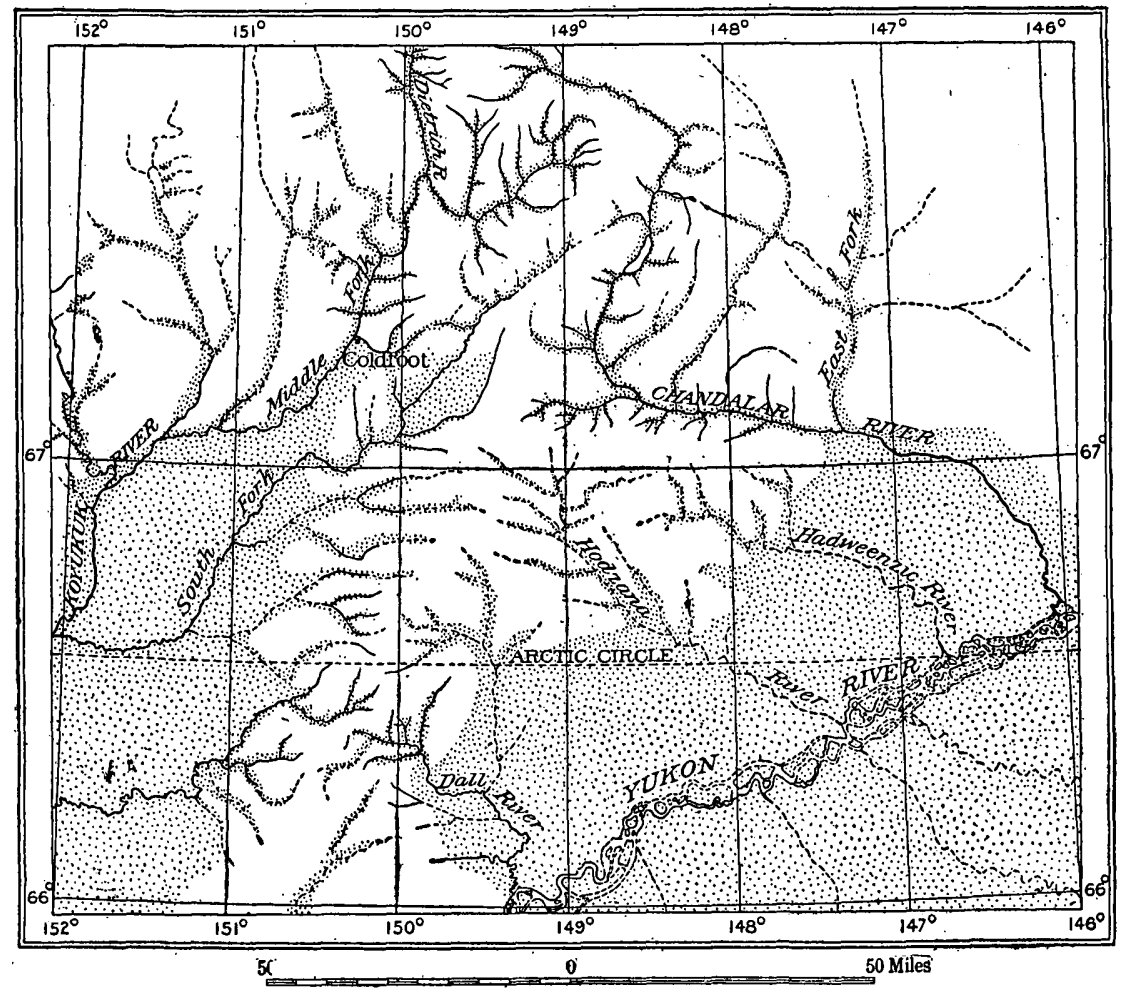

FIgURE 2.-Sketch map showing distribution of timber in Koyukuk-Chandalar region. Dotted areas are timbered.

The short summers, because of the long days, are generally warm enough to allow hardy vegetables to be grown to a good state of maturity in properly prepared gardens in the bottoms of the larger valleys, but killing frosts may occasionally occur in midsummer, even in the most favorable situations.

\section{VEGETATION.}

The flats of the Koyukuk-Chandalar region are timbered, and the forest growth extends up the mountain slopes and valleys to an altitude varying from 2,000 to 3,000 feet. A sketch map showing the 
distribution of timber is reproduced as figure 2. The timber is largely spruce, but poplar, birch, alder, and willow also occur. Spruce trees as much as 2 feet in diameter are found in the lower courses of some of the larger rivers. This size is exceptional, however, and most of the spruce averages less than 1 foot at the base. Grass suitable for stock is found in some open meadows in the flats and on the uplands above timber line. Moss is the prevailing vegetation at altitudes above 4,000 feet. Of the wild fruits blueberries are the most common, but red currants and cranberries are also found.

\section{ANIMAL LIFE.}

Large game is no longer found in the vicinity of the long-established mining camps. The region, as a whole, however, contains moose, caribou, mountain sheep, and bear. Of these the sheep and bear are most abundant. Other mammals in the region include gray wolves, mink, and ground squirrels. Ptarmigan and grouse are abundant in many parts of the region, and in summer geese and ducks are found along the streams and lakes. Salmon run up the Chandalar in summer, but do not reach the lake. Among other fish of the region are trout, grayling, pickerel, and whitefish. The native inhabitants rely on the fish and mammals for a large part of their food supply.

\section{POPULATION AND SETTLEMENTS.}

The white population of the Koyukuk region since 1900 has not been large. In the Klondike rush 1,000 or more inexperienced gold seekers entered the Koyukuk Valley in the fall of 1898, but nearly all of them departed during the early summer of 1899 and only about 100 of the more hardy ones remained. Although a revival of interest was caused in 1900 by the discovery of gold on Myrtle Creek and the reports of rich finds on Hammond Creek and the population again reached 1,000 or more, by .1901-2 it had dwindled to about 200 . About 350 are reported to have been there in 1903-4, and since then the average population of the district has been about 200 persons. In addition to these there are some natives both in the Chandalar and Koyukuk districts. The census of 1910 gives a total population, both whites and natives, for the entire region, of 823 . This, however, includes the settlements on the lower Koyukuk.

Since mining was established in 1900 the principal settlement in the Koyukuk region has been the town of Coldfoot, located on Koyuluk River about 586 miles from the Yukon, at the mouth of Slate Creek. Here the postal and recording offices are established; but about 1908 a new settlement was formed 16 miles farther up the 
Koyukuk, at the mouth of Wiseman Creek, and this place is now the largest town in the district.

A small group of cabins on the north bank of Chandalar River near the mouth of Flat Creek is named Caro. This place is about 110 miles from Fort Yukon and 35 miles from the placer diggings at the head of Big Creek. During 1907-8 it had a small population of whites and contained the postal and recording offices for the district: At present only a few natives remain, and the mining population of the district consists of some 20 or 30 white men, including the recording officer for the district, who reside near their claims about the head of Big Creek.

\section{TRANSPORTATION AND TRAILS.}

There is only one natural highway for approaching the Koyukuk district-that by way of Koyukuk. River. From the middle of June until early in September the main Koyukuk may be ascended by medium-sized stern-wheel steamboats having a draft of about 2 feet. By this means all the supplies for the region are now transported up the river to the vicinity of a warehouse station named Bettles, a few miles below the mouth of John River and about 60 miles below Coldfoot. During some seasons of low water it has been found impracticable to reach Bettles, and at certain periods of high water it is possible for steamboats to ascend a short distance above that place. The general practice is to take all supplies from Bettles, or a point near by, upstream to Coldfoot or the mouth of Wiseman Creek during the summer by shallow-draft scows that carry from 8 to 12 tons, towed by horses (Pl. VIII, $A$, p. 86 ), or by poling boats that carry about 1 ton, propelled by men. Both methods are tedious and expensive. From June 15 to September 15 may be considered the boating season on the Koyukuk.

Some freight has been hauled in winter on horse or dog sleds up the river from Bettles, and during the earlier years of development this was the common practice. At present this method is used for distributing supplies to the places of mining on the various creeks, supplemented to a small extent by packing with horses during the summer.

The freight charges during recent years have been, from Seattle or San Francisco to Bettles by ocean and river steamboats, 4 to 6 cents a pound; from Bettles to the mouth of Wiseman Creek by horse-towed scows, 6 to 8 cents a pound. Thus, it costs from 10 to 14 cents a pound, or $\$ 200$ to $\$ 280$ a ton, for freight charges alone from Seattle or San Francisco to the mouth of Wiseman Creek for all the merchandise brought into the Koyukuk district. Winter 
sledding of freight from Coldfoot to Nolan Creek is done for 4 cents a pound, and horse packing in summer from the mouth of Wiseman Creek to Nolan Creek for 6 cents a pound.

Practically all the passenger travel to or from the Koyukuk is by boat during the summer, and the heavy mail is also delivered during the open season.

There is also a summer overland route, seldom used, that leaves the west bank of Yukon River a little above and opposite the abandoned trading post called Fort Hamlin and follows the low ridges and benches that form the western border of Dall River valley, crosses the west fork of this river about 45 miles by the trail from the Yukon, goes over the mountains to the north into the headwaters of the south branch of Fish Creek, thence passes over the western ridges and slopes of the moderately high mountains that form the divide between the eastern tributaries of the Koyukuk and the headwaters of the Hodzana, crosses the Mosquito and South forks, and goes through Sitkum Pass and down Slate Creek to Coldfoot. This route is about 150 miles long, but because of the intricate arrangement of the various streams, the roundabout way it follows over the mountains above timber line, and the fact that the so-called trail is recognizable in only a few places below timber line, it is difficult to follow and is suitable only for cattle or packhorse outfits or pedestrians with guides who know the country. (See Pl. I, in pocket.)

To reach this district during the winter or closed season it is necessary to travel with dog-drawn sleds. A monthly winter mail service of this kind is maintained and a few persons occasionally travel in this manner. The present winter mail route goes down Koyukuk River from Coldfoot to the vicinity of Bergman, then across the lower valley of Kanuti River and over the low mountains forming its southern boundary into the upper drainage basin of the Melozitna, thence southeastward across another low mountain divide into the upper valley of Tozitna River and down that valley to the town of Tanana, on the Yukon, where a connection is made with the YukonTanana mail route to Fairbanks. The distance from Coldfoot to Tanana by this route is about 220 miles. Previous to 1906 mail, both in winter and summer, was carried to Coldfoot from Fort Yukon up Chandalar River and its West Fork, over a low divide, across the valley of the South Fork of the Koyukuk, over another low pass, and down Slate Creek to its mouth. The distance by this route is about 175 miles.

During 1910 the Alaska Road Commission commenced the construction of a trail for winter sledding and summer horse packing from Yukon River, which is intended to serve both the Chandalar and the Koyukuk districts. This trail leaves the Yukon at a newly 
established settlement named Beaver, situated on the north bank of the river about 100 miles below Fort Yukon. .It follows a general northwesterly direction for about 80 miles from Beaver along the rolling ridges that separate the valleys of Orenzik and Hodzana rivers to the divide between them and the Chandalar. Thence it forks into two branches, one to continue northwesterly across the upper part of the West Fork of the Chandalar, across the South Fork to the Koyukuk, and down Slate Creek to Coldfoot; and the other to cross the Chandalar River near Caro and continue northeastward up the Middle Fork of the Chandalar to Grave Creek and up Grave Creek to Little Squaw Creek. During high water small boats can ascend the Chandalar for about 75 miles.

\section{GEOLOGY.}

\section{PRINCIPAL FEATURES.}

The Koyukuk-Chandalar region is one of diverse geology, and the fragmentary data at hand do not permit a full analysis of all the many problems it presents.

The most widely distributed bedrock of the region is a series of metamorphosed sediments, including some altered igneous rocks, which are here correlated with the Birch Creek schist of the YukonTanana region. These rocks are succeeded to the north, along the central belt of the Endicott Mountains, by a massive semicrystalline limestone, interbedded with some argillites of Paleozoic age, probably Carboniferous. In the western part of the region there is a complex of ancient volcanic rocks, with some cherts and argillites, also believed to be of Paleozoic age (Devonian?), and probably older than the limestone just mentioned.

Mesozoic sediments are represented by a series of limestones, calcareous sandstones, and arkoses with some volcanic rocks, which are regarded as of Cretaceous age. There are also one or two small areas of loosely consolidated conglomerates, sandstones, and shales with lignitic coal beds, which are with reasonable certainty assigned to the early part of the Tertiary period.

The Quaternary is represented by widespread deposits of both fine and coarse glacial outwash, which occurs both as fills in deeply eroded bedrock depressions, the bedrock floors of which are below the present drainage gradients, and as terrace deposits above the present stream levels. The recent stream gravels and silts are largely reconcentrations from the older terrace deposits. Both consist of gravels, sands, and silts. Glacial moraines are also found in the northern half of the region. 
The igneous rocks include, besides the volcanic rocks mentioned above, large areas of granitic and dioritic intrusive rocks as well as stocks and dikes of similar composition. The intrusive rocks are locally altered to gneisses. Diabase dikes and sills also occur in some of the formations, notably in association with the ancient volcanic rocks already described. On the lower part of Chandalar River an area of Quaternary or Tertiary volcanic rocks has been noted.

The dominant structural lines trend a little north of east, thus paralleling both the Yukon Valley below the great bend on the south and the main axial line of the Endicott Mountains on the north. The older schists are closely folded, but the Paleozoic limestone series is thrown up into more open folds with many faults. The Mesozoic and Tertiary sedimentary formations are but little disturbed as compared with the older rocks. They are, however, locally folded to some extent and generally more or less tilted and faulted.

\section{GEOLOGIC MAP.}

The principal geologic features of the region are graphically summarized on the map ( $\mathrm{Pl} . \mathrm{V}$, in pocket). In the preparation of this map extensive use has been made of the surveys by Schrader and Mendenhall, whose results have been interpreted by the writer in accordance with his own views of the sequence. As no one geologist has covered the entire field, correlations for purposes of cartography must necessarily be uncertain and the relations of the various formations generalized. It is believed, however, that while this map is far from being accurate it may serve as a useful guide to prospectors by indicating the general distribution of the schists, which are the source of the placer gold, as well as the most important intrusive masses, which are believed to have influenced the gold-bearing mineralization in the schistose bedrock. The mapping of the Mesozoic rocks is also important to the prospector, as these rocks are not likely to be found gold-bearing over belts of any extent. Where they are locally intruded by granite rocks, however, they may contain small bodies of contact-mineralized rock, which yields placer gold, as is the case in the well-known Iditarod district about the head of Flat Creek.

$76032^{\circ}-$ Bull. $532-13-3$ 


\section{GENERAL SECTION.}

The following table shows the geologic column in this region in a generalized manner:

Generalized stratigraphic sequence in the Koyukuk-Chandalar region, .Alaska.

\begin{tabular}{|c|c|c|c|}
\hline Era. & System. & Series. & Lithologic character. \\
\hline \multirow{4}{*}{ 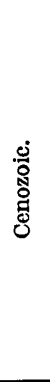 } & \multirow{2}{*}{ Quaternary. , } & \multirow{2}{*}{$\begin{array}{l}\text { Recent. } \\
\text { Unconformity.- } \\
\text { Pleistocene. }\end{array}$} & $\begin{array}{l}\text { Stream gravels, sands, and silts, with muck, peat beds, } \\
\text { and "flood-plain"" ice, also some glacial deposits within } \\
\text { the Endicott Mountains. }\end{array}$ \\
\hline & & & $\begin{array}{l}\text { Terrace and basin-fill silts, clays, sands, and gravels, with } \\
\text { widespread glacial outwash along the southern border } \\
\text { of the Endicott Mountains. }\end{array}$ \\
\hline & $\begin{array}{l}\text { Unconformity. }-\overline{\text { Ter- }} \\
\text { Quaternary or Ter- } \\
\text { tiary. }\end{array}$ & & Effusives, basaltic and andesitic lavas and tuffs. \\
\hline & Tertiary. & & $\begin{array}{l}\text { Shales, sandstones, and conglomerates, with some lignitic } \\
\text { coal beds. }\end{array}$ \\
\hline \multirow{2}{*}{ 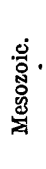 } & & & $\begin{array}{l}\text { Limestones, calcareous sandstones and shales, and } \\
\text { arkoses, with some volcanic rocks, and possibly some } \\
\text { coal beds. }\end{array}$ \\
\hline & \multirow{2}{*}{$\begin{array}{l}\text { Unconformity. } \\
\text { Carboniferous(?). }\end{array}$} & & $\begin{array}{l}\text { Granitic and dioritic intrusive rocks, locally sheared and } \\
\text { gneissoid, possibly not all of Mesozoic age. }\end{array}$ \\
\hline \multirow{3}{*}{ 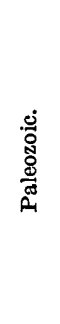 } & & & $\begin{array}{l}\text { Massive crystalline and semicrystalline limestones with } \\
\text { schistose bands. }\end{array}$ \\
\hline & \multirow{2}{*}{$\begin{array}{l}\text { Devonian (?). } \\
\text { Unconformity. } \\
\text { Pre-Ordovician (?) } \\
\text { (Birch Creek } \\
\text { schist). }\end{array}$} & & $\begin{array}{l}\text { Cherts, slates, quartzites, and thin beds of limestone, with } \\
\text { basic igneous rocks, tuffs, and alteration phases, some } \\
\text { doubtrul greenstones and hornstones. }\end{array}$ \\
\hline & & & $\begin{array}{l}\text { Quartz-mica schists, schistose quartzite, phyllites, slates, } \\
\text { amphibolite schist, and highly crystalline limestone. } \\
\text { Cut by granitic and dioritic intrusive rocks, mostly of } \\
\text { Mesozoic age, but some possibly of Paleozoic age. The } \\
\text { gold-bearing formation of the region. }\end{array}$ \\
\hline
\end{tabular}

\section{BIRCH CREEK SCHIST (PRE-ORDOVICIAN?).}

\section{GENERAL FEATURES.}

The Birch Creek schist is in the main composed of highly altered sandstones and shales. Most of the rocks included in this formation have been sufficiently metamorphosed to be in large part recrystallized. The most common rock types are quartzite schists, always containing considerable mica, and finely foliated micaceous and graphitic schists. In the Koyukuk placer district this formation is largely represented by carbonaceous schists, phyllites, and slates. Within the area here mapped as Birch Creek schist there are also some foliated amphibolites or hornblende schists and a few limestones of a highly crystalline and in some places schistose texture. The highly altered igneous rocks of the amphibolite (hornblende) schist 


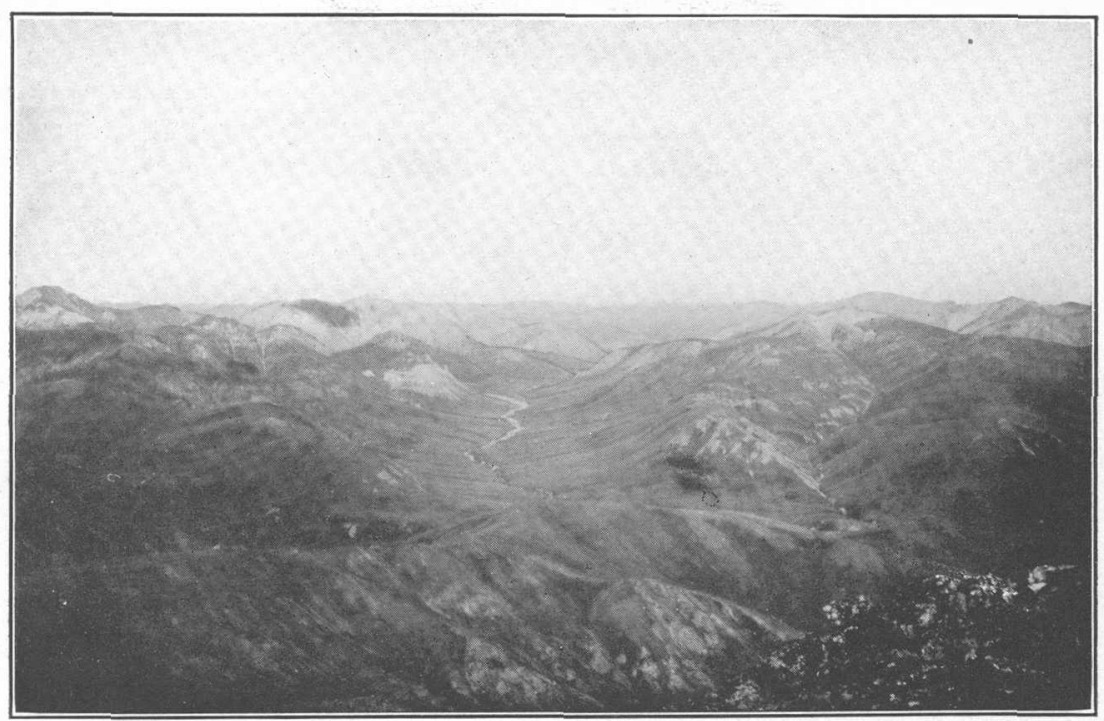

A. LIMESTONE AND SCHIST CONTACT I:. ENDICOTT MOUNTAINS.

Looking N. $15^{\circ}$ E. from Horace Mountain. Light-colored mountains in background are limestone.

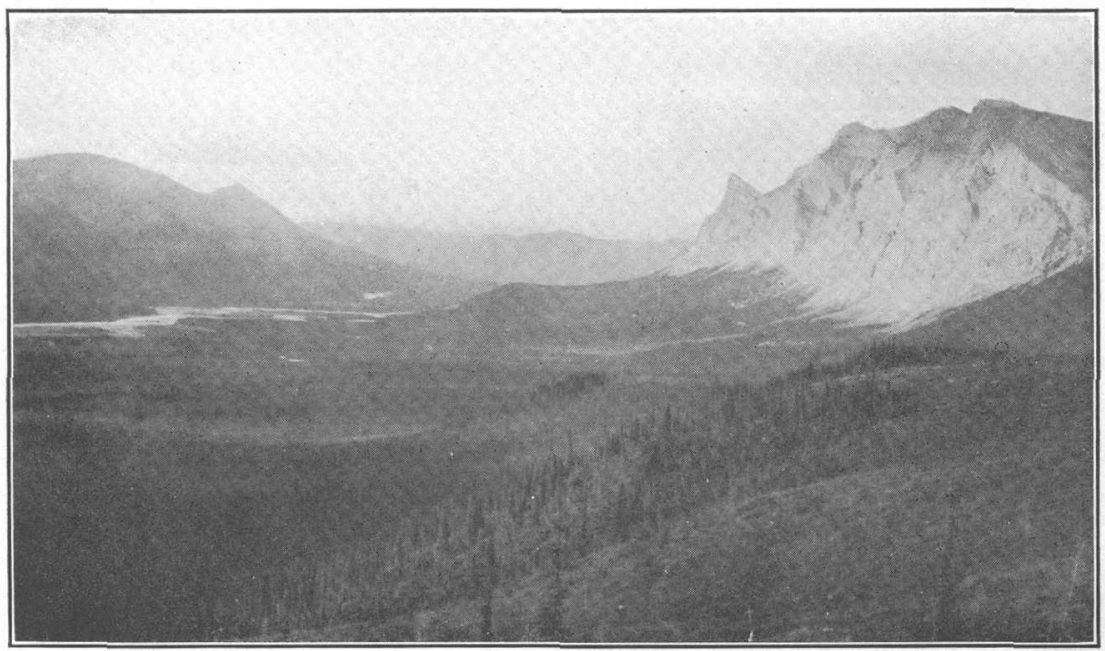

B. LIMESTONE CLIFFS SOUTH OF BETTLES RIVER, A POSSIBLE FAULT SCARP. 
type, in part at least, most probably represent metamorphosed basic volcanic rocks that flowed out and became more or less conformably incorporated with the sedimentary rocks comprising the main part of the Birch Creek schist when they were deposited. This inference is drawn from the fact that the igneous schists are in some localities apparently interbedded with the schists of sedimentary origin, and if it is generally correct the relative positions, attitudes, and distribution of some of the amphibolite schists may have more or less stratigraphic significance. On the other hand, in some places these altered basic igneous rocks appear to cut across the sedimentary rocks that contain them, so until the details of their various forms of occurrence are closely studied they will be of little aid in deciphering the history of the schists and can not be separated from them. In addition to these old basic, lavalike rocks the schists also contain, in some areas, large amounts of acidic intrusive rocks of granitic and dioritic kinds, which in some places are closely associated and here and there appear to intergrade in composition. The granitic rocks occur both in large, massive intrusive bodies, locally porphyritic, and in more narrow dikelike forms, which were evidently injected into the country rock, for the most part at a time considerably after the schistose structure of the sedimentary deposits had reached an advanced stage of development.

The schists and the igneous rocks they contain constitute two very widespread belts of bedrock in this region. (See map, Pl. V, in pocket.) . One of these belts forms a large part of the Hodzana highland, the irregular area of moderately mountainous relief bounded on the south and east by the Yukon Flats, on the northwest by the Koyukuk Valley, and on the north by a broad depression which separates the highlands from the southern foothills of the Endicott Mountains. (See p. 13.)

The other schist belt makes up the southern ranges and foothills of the Endicott Mountains. The schists are bounded on the northwest by massive crystalline limestones, beneath which they appear to dip, although the contact relations may be those of faulting. (See Pl. VI, A.) This schist belt varies in width from 15 to 30 miles, and extends southwestward from the general vicinity of Chandalar Lake across the Middle Fork of the Koyukuk to and beyond John River.

In this region these two belts of schists have been examined only along the routes followed in reconnaissance field work, which necessarily covered but a small portion of the area occupied by a series of rocks of widespread distribution. Consequently the present knowledge of the characters and relations of the Birch Creek schist in this region is too incomplete to permit the separation of the formation 
into definite subdivisions. Mendenhall, ${ }^{1}$ who examined that part of the Hodzana highland schist belt about the headwaters of Dall and Kanuti rivers, grouped all the schistose sediments and their associated igneous rocks of various type and relations together under the general title "metamorphic complex." $\mathrm{He}$ considered this diverse complex to include, in whole or in part, the equivalents of the Birch Creek schist and the Fortymile "series" ${ }^{2}$ so widely distributed south of Yukon River; the Kigluaik group, Kuzitrin formation, and Nome group of Seward Peninsula; and the "Rapids" schist and "Lake quartzite schist " of the northern schist belt of the Koyukuk-Chandalar region. This broad classification was suggested because it appears to be the only practical way of grouping together all the older rocks, which present many of the same characteristics and general lithologic features and also show considerable although varying metamorphism, which affects all the rock types however diverse; and because it affords a clear basis for separating them from the younger unaltered, or but little altered, sediments and lavas that occupy the intervening areas.

\section{LITHOLOGY, DISTRIBUTION, AND STRUCTURE.}

\section{DALI RIVER AREA.}

Mendenhall ${ }^{3}$ describes the rocks of the Dall River area as follows:

[Metamorphic complex].-The old rocks [of the metamorphic complex] were first encountered along upper Dall River, where the hills in which it heads rise from beneath the silts of the Yukon Basin [Flats]. It is out of these rocks and the granitic intrusives which cut them that the broad ridges and spurs were carved from which the waters of the Dall, Swift [Hodzana], and Kanuti rivers and many Koyukuk tributaries flow. The phase most commonly displayed here is a fine even-grained quartz-biotite schist, with very fine and straight lamination-a true metamorphic rock of uncertain origin. This type makes up the great mass of the schistose rocks of this area. With the intrusives which cut it, it forms the divide between the Yukon and the Koyukuk and the higher parts of the branching spurs where these were examined. * * Away from the intrusive centers the rock is oftener coarser, less quartzose, and less finely and evenly laminated. Other micas than biotite sometimes appear, and by gradations schists are encountered which are clearly sediments carrying graphite and calcite. Interbedded with schists like these [on both the Dall and the Koyukuk sides of the divide] are three or four bands of gray, often very coarsely crystalline limestone, standing at high angles and striking nearly east and west.

South of the flats at the head of the Kanuti River a series of dark finegrained slates and dark quartzites form the lower slopes of the wall of the valley.

1 Mendenhall, W. C., Reconnaissance from Fort Hamlin to Kotzebue Sound, Alaska: Prof. Paper U. S. Geol. Survey No. 10, 1902, pp. 31-37.

2 Spurr, J. E., Geology of the Yukon gold district, Alaska: Highteenth Ann. Rept. U. \&. Geol. Survey, pt. 3, 1898, p. 140.

Mendenhall, W. C., op. cit.; pp. 32-33. 
Intrusives.-The schists [of the Hodzana highland] are extensively cut by uniform bodies of granite porphyry, which in some parts of the region occupy greater areas than the rocks into which they have been forced. These masses are particularly abundant north of the upper course of the Kanuti River [on the divide between it and the southern branch of Fish Creek] and among the bills northwest of the eastern branch of the Dall.

On the [west side of the main] Dall River [a few miles above the point where it leaves its valley to enter the Yukon Flats] granites which are not porphyritic and not schistose, though deeply weathered, outcrop along the stream section [and extend southwestward, forming the foothills that bound the northwestern part of the Yukon Flats. These are intruded into the schists. About 15 miles west of the mouth of Dall River a massive body of porphyritic granite forms a rounded mountain about 3,000 feet high]. On the hill slopes to the north [of Dall River] occasional narrow and compact acid dikes are exhibited. These are regarded as offshoots from the main intrusive mass.

In addition to these unaltered intrusives, gneissoid porphyritic rocks of granitic and dioritic composition occur in the schists. Sometimes the crushing has gone so far as to suggest that some of the biotite schists may themselves be derived from igneous rocks of like character, but as no instance was observed in which the distinction could not be clearly made, this suggestion remains unproved. It is true, however, that the intrusion began before the metamorphic action had ceased, so that the earlier intrusives were greatly affected by it.

The geologic time at which the granitic intrusive activity was at its maximum development is not determinable from any'stratigraphic evidence in the area under consideration, but its general development in other parts of Alaska; especially throughout the widespread areas occupied by the Birch Creek schist, indicates it to be a characteristic event of much geologic importance, both historically and economically, for in many places the bedrock mineralization that has been stimulated by these intrusions seems to have produced the goldbearing zones from which the placer gold has been derived. In certain areas of minor extent the Birch Creek schist is unconformably overlain by sediments of Cretaceous age, both the younger sedimentary rocks and the old schists being cut by the same granitic intrusive rocks which occur so commonly in some portions of the schists. From this evidence it is provisionally inferred that most of the granitic rocks were intruded during later Cretaceous time. Although at some localities the Cretaceous sediments are somewhat generally altered over considerable areas, at others they have been affected only slightly by contact metamorphism. This might be interpreted as evidence that the more active metamorphic influences culminated at about the close of the period of granitic intrusive activity.

The schists that extend northward from Fish Creek to the southern branches of Jim River appear to be quite free from intrusive rocks, but the northern front of the Hodzana highland, from the headwaters of Jim River eastward along the south side of the Chandalar Valley to a point opposite the mouth of the East Fork of the Chandalar, 
is made up largely of a belt of intrusive granitic rocks. The west end of this belt of rocks is composed mostly of porphyritic granites. Toward its east end, along the south side of the Chandalar, it is in large part a gneissoid granite which is considerably crushed and sheared and shows the effects of dynamic action, being in some places so highly sheared and altered as to partake of the nature of a granitic mica schist. In some zones the rock is so folded, jointed, and cleaved that it can not be distinguished ordinarily from a true biotite schist. These older phases are intruded by an apparently younger and fresher-looking granitoid rock, which is medium grained and more or less porphyritic. On fresh surfaces this rock has the appearanee of a typical gray granite; in composition it is found to be a granodiorite. It occurs as dikes in the gneissoid rocks, which are also cut by narrow acidic aplite dikes of a light-gray color composed of fine and even grained quartz and feldspar, with a very small amount of green, apparently chloritic mica.

Along the south side of Chandalar River the granitic rocks have a known extent of 25 miles. From the reports of prospectors they are judged to continue westward to the area known to occur on upper Jim River and southward for some distance as the most common rock of the broad, even ridges and higher mountain areas in the northern part of the Hodzana highland.

The dominant bedrock structural features throughout the Hodzana highland trend generally in directions from east-west to northeastsouthwest, and the longer dimensions of the intrusive masses and dikes usually follow the trends of the schists that contain them.

\section{KOYUKUK-CHANDALAR AREA.}

GENERAL FEATURES.

The Birch Creek schist as developed in the northern KoyukukChandalar belt was provisionally divided into three formations by Schrader, who separated the schists on the basis of lithologic and structural differences, which, though evident enough at particular localities, have not yet been studied with sufficient detail to make it possible to distinguish and separate their varying phases with facility throughout the region. It will be impracticable to apply these probable divisions of the metamorphosed sediments with any degree of exactness until their areal development and distribution have been carefully traced and plotted upon a map of sufficient detail to show their complicated structural and lithologic interrelations. The three divisions of schistose rocks recognized by Schrader ${ }^{1}$ were named-in ascending order from those which he at that time thought the oldest-

\footnotetext{
1 Schrader, F. C., Preliminary report on a reconnaissance along the Chandlar and Koyukuk rivers, Alaska, in 1899 : Twenty-first Ann. Rept. U. S. Geol. Survey, pt. 2, 1900, pp. $472-475$.
} 
the Rapids schist, the Amphibolite schist, and the Lake quartzite schist. Schrader considered that only the youngest of these three divisions, the "Lake quartzite schist," might probably be correlated with the Birch Creek chist, as originally defined by Spurr ${ }^{1}$ in the Fortymile and Birch Creek placer districts, south of Yukon River, where this name was applied to a group of rocks " consisting mostly of quartzite schists, grading into finer-grained, often graphitic schists." Schrader also recognized, however, the possibility that the "Rapids" schist is merely a lithologic phase of the lower part of the "Lake quartzite schist"-in other words, that these two divisions should be more properly considered as comprising one unit, for he says, "It [the "Rapids" schist] seems to underlie the Lake quartzite schist, but may prove to be a lower member of this series, so altered by metamorphism as to bear little resemblance to the general [and more widespread] type [of the "Lake quartzite schist"]." For the present, at least, the writer is inclined to consider the schists of sedimentary origin as a unit rather than attempt to separate them. In this connection it may also be well to suggest the possibility that the amphibolite schist is in reality younger than the "Lake quartzite schist," on the ground that it may represent a highly metamorphosed phase of diabasic or dioritic effusive or intrusive rocks which were either poured out upon the sedimentary beds of the "Lake quartzite schist " before they were altered into their present highly schistose condition or intruded into them before or early enough during the period of their metamorphism to have suffered the same changes in greater or lesser degree, at least in some areas. In the present report it is deemed most satisfactory to consider Schrader's three groups of schists to be merely members of the Birch Creek schist as this formation is now defined. The principal parts of Schrader's descriptions as qualified above are given below, with only such modifications of arrangement and slight omissions as are necessary to fit them to this necessarily generalized interpretation.

\section{"RAPIDS" SCHIST.}

This term refers to a narrow belt of highly metamorphosed or altered mica schist traversed by the Chandalar River in the region of the rapids [about 8 miles below Chandalar Lake], where the schist forms a low anticline, with much quartz, in the bight of the fold. Here the rock embracing the rapids fxtends for several miles downstream [to Horse Creek]. This rock in geological horizon is supposed to [be the oldest]. It seems to underlié the Lake quartzite schist, but may prove to be a lower member of this series, so altered by metamorphism as to bear little resemblance to the general type. In the region of the rapids, and to some extent below, the rock is a biotite schist, closely appressed or crowded into numerous short folds, and contains much quartz; some garnet, and other metamorphic minerals.

1 Spurr, J. E., Geology of the Yukon gold district, Alaska: Eighteenth Ann. Rept. U. S. Geol. Survey, pt. 3, 1898, p. 141. 
The trend is east and west. At a short distance below the rapids the dip is southward, while above the rapids it soon becomes northerly. [This formation was noted along the river and extends southwestward across the valley of Horse Creek.] From its mineralized character it would ordinarily be regarded as one of the most auspicious to be examined for mineral resources. [Prospects of placer gold are reported to occur in the gravels of Horse Creek.]

On the Middle Fork of the Koyukuk, at the mouth of Bettles River, occurs a small area of what appears to be much the same rock. [It seems to dip beneath the heavy-bedded limestones that make up the mountains to the northwest, but the stratigraphic relationships in this vicinity are complicated by faulting.]

AMPHIBOLITE [HORNBLENDE] SCHIST.

[This rock] is a fine-grained fissile or fibrous schist of apple-green color. [Some of it is so siliceous as to] partake largely of the nature of a micaceous quartz schist. The quartz, however, is [generally] disposed in small bands and veinlets, all of which have suffered flexing and folding, the small folds often occurring in the most recumbent manner. The presence of sulphides and occasionally carbonates denotes mineralization. Assays of the contained quartz show it to carry both silver and gold [specimens obtained near the base of Green Mountain, on Chandalar River, yielding about 0.42 ounce of gold and 0.14 ounce of silver to the ton of quartz, or a money value of about $\$ 8.50$ a ton of picked specimen quartz].

Judging from the apparent position of this rock in the geologic horizon it ranks among the older rocks of the region. It is apparently younger than the Rapids schist; and it seems to occupy a lower horizon than the Lake quartzite schist, which may provisionally be referred to the Birch Creek series. * * * It occurs on Chandalar River; about 3 miles above Bend Mountain. Here it is not, as usual, restricted to the floor of the valley, but seems to be the conspicuous rock in a mountain of moderate size known by the prospectors as Green Mountain. Along with gray mica schist and limestone, it forms the mountainous slope fronting the valley to the north. Back of this front it seems to have a somewhat wider extent to the northward. At the base of Green Mountain, near the edges of the valley, the schistosity trends northeast and southwest, with dip gently northwestward.

In the floor of the [Chandalar] valley a few miles below Portage Creek the schist forms a low bench of some prominence, whose surface is about 25 feet above the present level of the river. It was next met with on Robert Creek, at about the same elevation as on Chandalar River, to the northeast of Horace Mountain, where it exclusively forms the low bluffs and benching along the uortheast side of the creek. It occurs also in Robert Creek canyon. On Dietrich River, at about 5 miles below Fault Mountain, on the north edge of the valley, it again forms a low bench rising to about 20 feet above the river. The trend of the schistosity here is northeast and southwest, with a dip of about $35^{\circ}$ southeastward. Here the rock also has a pitch or plunge structure, with a dip of about $20^{\circ}$ southeastward. A couple of exposures of limited extent were also met with at the base of the mountains along the Middle Fork of the Koyukuk River, between Bettles River and Slate Creek. Here gray micaceous quartzite schist, probably referable to the Birch Creek formation, seems to rest upon it.

$$
\text { “LAKE QUARTZITE SCHIST." }
$$

[This formation] so far as observed is principally a micaceous quartzite schist, though in some localities the mica becomes the dominant essential 
mineral. The quartz grains are usually rolled and rounded, denoting a sedimentary origin. Besides biotite, which is usually greenish, some muscovite and chlorite also occur. Magnetite as an accessory is often present in considerable amount. Garnet has been sparingly noted. In some instances the minerals are considerably crushed and the foils of blotite mica bent and flexed about the quartz. In other cases there is present considerable graphitic material, giving to the rock occasionally the aspect of a graphitic schist. The rock carries some quartz veins of moderate size, trending usually parallel with the schistosity, while some deviate or run nearly at right angles to it. A few exhibit mineralization, though this is not pronounced.

This rock is here called the Lake quartzite schist because of its great promlnence at Chandalar Lake. In the bend of the lake [on its west side] it forms a steep-faced cliff, rising nearly 2,000 feet above the lake, offering a fine exposure of structure and jointing. It seems probable that with future examination this rock may be correlated with the Birch Creek schists [south of Yukon River].

Geologically this rock overlies the Rapids schist, and it apparently underlies the limestone series on the northwest. In distribution it seems to extend from near the West Fork of Chandalar River [Crooked Creek] northward to beyond the lake, and from east of Chandalar River westward to the Middle Fork of the Koyukuk. It is apparently one of the chief rocks constituting the rugged mountainous mass [between these rivers, some of the peaks of which rise] to a height of nearly 6,000 feet.

From near the West Fork of Chandalar River to near the rapids the dip is southerly, but above the rapids, near the head of the lake, it becomes gently uorthwestward, the divergent dips apparently denoting the two sides of an anticline, the rock being thus more or less conformable with the Rapids schists. [The strong probability that the "Rapids" schist is merely a lower member of the widespread schist group of this area has already been stated.]

Concerning the more widespread areal distribution of the Birch Creek schist in the Chandalar region, it may be said that the formation is known to extend northeastward at least as far as the Lake Creek and Grave Creek valleys, and that prospectors report its occurrence farther east on the headwaters of the Middle Fork of the Chandalar.

\section{INTRUSIVES.}

In the Koyukuk-Chandalar belt of Birch Creek schist granitic intrusive rocks do not appear to be as extensive or as widely distributed as they are in the Hodzana highland belt. The only considerable area of them now known appears to form a prominent part of the high rugged range which extends northeastward from the head of Baby Creek to the elbow of Chandalar River at Bend Mountain, about 15 miles above Chandalar Lake. On the northeast the granitic rocks appear to cross Chandalar River and extend into the Bend Mountain area. Their extent southwestward from Baby Creek is not known, but the high, rugged topographic forms that seem to be characteristic of their massive occurrence appear to diminish in this direction. West of these mountains, however, granitic rocks appear to extend 
across the valley of Robert Creek to Horace Mountain, opposite the mouth of Sheep Creek. Northeast of Horace Mountain the intrusive rock extends in the direction of Geroe Creek and Bend Mountain. Southwest of Horace Mountain, for a distance of 10 miles, nearly to Limestone Creek, the same rock seems to form a somewhat prominent line of rugged peaks rising to heights of nearly 6,000 feet along the northwest side of Bettles River.

The rock of the Baby Creek area has received only a cursory examination, but seems to be a granodiorite, being composed of feldspar, with some quartz, hornblende, and green mica. It is a light-colored rock with greenish tinge and medium grain. Locally it has been considerably sheared and altered to schist, but a large part of it seems to be in a comparatively unaltered condition. It is probably the bedrock source of the fresh granitic bowlders that occur in considerable quantities throughout the unconsolidated filling of the Chandalar Valley below Bend Mountain. In fact, the present channel of Chandalar River from the rapids below the lake to the mouth of the Middle Fork is clogged with bowlders of this kind of rock, which, owing to the considerable grade of the valley throughout this section, are so disposed as to form an almost continuous succession of swift riffles.

At a point about 3 miles south of the head of Chandalar Lake the schists are cut by a greenish dioritic dike several hundred feet in thickness, which has a northeast-southwest trend. East of Chandalar Lake the mountain mass on which Big, Tobin, Bowlder, Big Squaw, and Little Squaw creeks have their sources contains a considerable amount of dioritic intrusive rock with which the gold-bearing quartz veins of this locality appear to be associated. (See p. 111.)

The intrusive rock of Horace Mountain is also of a dioritic nature. The upper thousand feet or more of this mountain is apparently a large dike intruded into the schists of this region. The intrusive character is inferred from the completely altered condition of the country rock along the zone of contact, which in some places is 100 yards or more in width. The trend of this intrusive rock is northeast and southwest. In texture it varies from a medium-grained, somewhat gneissoid rock to a schist, and in its various stages it seems to show passage by dynamic action from a greenish-gray speckled augite diorite to an amphibolite schist. The southeastern slope of the mountain is traversed by a more or less mineralized belt a quarter of a mile wide. Here the rock seems to consist principally of quartz, which is greatly crushed, sheared, and folded and is stained a bright red. The staining material has not been examined closely, but is probably hematite.

Intrusive rocks are much less prominent to the west, in the Koyukuk area of the schist, than in the Chandalar district. With 
the exception of a dioritic dike on Gold Creek, another that crosses Myrtle and Slate creeks, and the rocks reported to occur in the mountains between the sources of Emma and Wiseman creeks and possibly west of Nolan Creek, a northern tributary to Wiseman Creek, no igneous rocks, either intrusive or effusive, have been noted in this area.

The Gold Creek dike is situated about 3 miles above the mouth of that stream, where it forms a small canyon several hundred yards long. It strikes northeast and southwest and stands about vertical. Its outcrop is noticeable up the north slope of the valley to its crest, but beyond this point its extent has not been traced. To the southwest from the point where it crosses Gold Creek it has been observed for only a few hundred yards, being covered beyond by talus and vegetation.

The intrusive rock reported to occur in the mountains on which Emma and Wiseman creeks have their sources was not observed in place by the writer, but the numerous large dioritic bowlders in the gravel deposits of the Emma Creek valley, which, according to the statements of prospectors, are derived from intrusive bodies in the mountains about the head of the creek, indicate that considerable masses of this rock occur there. Some bowlders of this same kind of intrusive rock occur in the gravels of the Wiseman Creek valley, and may be derived from the same mountains or from the ridges west of Nolan Creek, a north-side tributary of Wiseman Creek.

The intrusive rocks on Gold and Emma creeks lie in a broad way along the general strike of the schistose country rocks that contain them, and are in trend with the belt of intrusive rocks which extends along the northwest slope of the Bettles River valley from Horace Mountain to a point near the mouth of Limestone Creek. There is, however, no evidence at hand to show that these rocks are in direct relation with each other, but it may be that they were intruded at the same time under similar conditions.

A dike similar to those on Gold Creek and Chandalar Lake occurs on Myrtle and Slate Creeks, in the Koyukuk district. It crosses Myrtle Creek about $1 \frac{1}{2}$ miles above its mouth and extends southwestward across Slate Creek about 2 miles below the mouth of Myrtle Creek. It also extends northeastward into the mountains that form the southeast side of the Myrtle Creek valley, where it has the same general strike (northeast-southwest) and dip $\left(35^{\circ}-55^{\circ} \mathrm{SE}\right.$.) as the schists which contain it. The northeastern extension of these mountains may also contain more or less of this intrusive rock, for the valley of Boulder Creek, about 8 miles east of Myrtle Creek, has a considerable quantity of bowlders and cobbles of this kind of rock in its stream gravels. 
JOHN RIVER AREA,

On John River, about 50 miles west of the Middle Furk of the Koyukuk, Schrader ${ }^{1}$ observed a highly schistose group of rocks which he described under the name Totsen series, but which are here classed with this belt of Birch Creek schist. Schrader's description is in part as follows:

\section{TOTSEN SERIES (SILURIAN).}

Character and occurrence.-This series of rocks occupies a belt about 12 miles wide on John River. It lies south of the Skajit formation [which consists of heavy-bedded crystalline limestone and mica schist resembling and probably corresponding to the more schistose phase of the Bettles "series" that occupies the northern part of the Koyukuk-Chandalar region. On the south it is unconformably overlain by the Bergman "series," consisting of unaltered sediments of Cretaceous age. The rocks of the Totsen "series"], are mainly mica schists and quartz-mica schists, in both of which the essential minerals are biotite and quartz. There is also some much-altered greenstone or amphibole schist. Locally the mica schist becomes graphitic, graphite bodies one-eighth inch in diameter being noted, and in some cases the rock carries much secondary quartz, both in small veins and in lenticular bodies. Some iron pyrite is also present, which on oxidation gives a reddish-brown color to the rock. The quartz veins tend to follow the schistosity and are often locally contorted and twisted. Some carry irregular veinlets or stringers of epidote.

The series is believed to be essentially of sedimentary origin, but the sedimentation seems to have been accompanied by basaltic flows, which were later sheared with the sedimentary beds, giving rise to amphibolite schist, of which the most prominent strip, having an apparent width of several miles, occurs near the southern part of the belt occupled by the series [as exposed along John River]. Here the [amphibolite] rock, judging from the bent and crushed remnants of feldspar and augite shown under the microscope, is plainly of igneous origin. Though on account of faulting and folding there is doubtless some duplication of the rocks of the Totsen series [as it occurs along John River], its total thickness, judging from the prevailing dip and distance across the strike, is 6,000 and 7,000 feet.

Structure.-The Totsen series, like the older rocks composing the range, trends approximately east and west, and though the series as a whole has been intensely folded, the dip in general is monoclinal, being, so far as observed, southward, at angles of $60^{\circ}$ to $80^{\circ}$. [It must be borne in mind, however, that such a monoclinal attitude may be that of overturned folds whose tops have been truncated.] In the northern part of the belt John River valley, for a distance of several miles, seems to follow a north-south syncline in the series. The series is traversed by the major northeast jointing of the range and by a secondary structure at nearly right angles to the major jointing. Cleavage was noted at a few localities, but apparently much of this has been obliterated by disturbance.

Age and correlation.-The Totsen "series," so far as observed, "consists essentially of rocks that seem undoubtedly to belong to the class of older crystalline schists" which are so widely distributed

1 Schrader, F. C., A reconnaissance in northern Alaska : Prof. Paper U. S. Geol. Survey No. 20,1904 , pp. $58-60$. 
throughout the interior of Alaska. As far as now known it can not be correlated with any of the formations that make up the major part of the Endicott Mountains to the north, for all of these are apparently younger.

According to Schrader, "the Totsen series can be correlated in a tentative way, on lithologic grounds, with the Lake quartz schist of Chandalar River." As made up in the section exposed along John River thesé rocks appear to be more micaceous and to contain much less quartz and more greenstone schist than the thick members of sedimentary origin that occur in the Koyukuk and Chandalar districts. Nevertheless, at some localities on John River the Totsen very much resembles the more altered phases of the schists east of the Koyukuk, in the Slate-Myrtle Creek placer diggings, which in turn have been correlated with the "Lake quartzite schist" of Chandalar River.

SUMMARY.

CORRELATION.

The country rock of the Hodzana highland and the Koyukuk and Chandalar gold districts is largely made up of different kinds of highly altered sedimentary rocks, which are similar to and apparently in large measure the same as the old formations that are known to form the bedrock over extensive areas throughout the interior of Alaska, both north and south of the Yukon and westward into the Kobuk Valley and Seward Peninsula. These old schistose rocks may be differentiated into several indefinite groups, but in general it is most satisfactory for the present to assemble them together, for they show many similar characteristics and intimate interrelations, especially in regard to their widespread regional metamorphism and the economically important fact that the mineralization developed within them during their transformation was accompanied by the segregation of gold-bearing minerals in some of their members, from which free gold has been derived and concentrated into placers.

In the region under consideration these rocks make up a diverse complex of more or less schistose sediments, in some places associated with igneous rocks of various types and relations. Many different phases of the schists have been recognized, but because of the variations in the rocks from place to place enough evidence to warrant their definite subdivision, correlation, and classification has not yet been gathered, particularly in the region north of the Yukon. South of the Yukon, between that river and the Tanana, the general sequence of the rocks, beginning with the oldest, appears to be quartzite schists, carbonaceous and graphitic schists, quartz-mica schists, garnetiferous schists, crystalline limestones, and altered igneous rocks largely intruded into the sediments. These rocks are called the Birch 
Creek schist and are considered to be of early Paleozoic age, probablv pre-Ordovician. North of the Yukon rocks that are considered to belong to the Birch Creek schist occupy two wide belts which have been described on pages 34-45. The rocks of the Hodzana highland belt appear to be similar in every particular to those of the YukonTanana region and contain a considerable amount of igneous intrusive rocks, mostly granite porphyries, both unaltered and metamorphosed. This belt of Birch Creek schist appears to extend more or less continuously southwestward along the divide between Kanuti and Yukon rivers and probably connects with the Birch Creek schist that occurs in the Gold Hill district, on the north bank of the Yukon about 25 miles below the mouth of Tanana River.

The northern or Koyukuk-Chandalar belt of Birch Creek schist is 10 to 30 miles wide, extending from the Chandalar Lake region across the Koyukuk Valley between Slate and Gold creeks and southwestward across the lower John River valley. Its distribution east of the Chandalar Lake region is not known, but to the west and southwest it extends to the Kobuk Valley and Seward Peninsula, where part of it forms the gold-bearing bedrock of the Nome, Candle, and other districts. On Slate Creek and generally throughout the Koyukuk placer district a phase of the Birch Creek schist consisting of carbonaceous schist, phyllite, and slate is common. To the northeast, in the vicinity of Chandalar Lake and southward along Chandalar River to Horse Creek, these rocks are more quartzitic and micaceous but also contain graphitic phases. To the southwest the lower part of the John River valley is crossed by a belt of schistose rocks, largely of sedimentary origin, which are locally graphitic and contain much secondary quartz, like the Carbonaceous schists of the Slate Creek valley. In the Koyukuk area the Birch Creek schist does not appear to contain the large amounts of igneous intrusive rocks that are characteristic of the area between the Tanana and the Yukon and of the Hodzana highland.

\section{STRUCTURE.}

The broad general trends of the. dominant structural features of the Birch Creek schist throughout both the Hodzana highland and Koyukuk-Chandalar belts vary from east-west to northeast-southwest. The dips of the bedding planes are for the most part at steep angles to the north or south, being in many exposures nearly vertical, but some dips are as low as $35^{\circ}$. For some of the broad sections that show generally consistant dips in opposite directions from or toward assumed axes of folding, which have not been definitely located or traced, tentative interpretations of anticlinal or synclinal structure have been suggested. What appear to be sections of considerable stratigraphic thickness across some areas where the strike 
and dip are uniform give the impression that a unonoclinal structure prevails. Such attitudes of the schists, however, may prove, when opportunity offers for examining them closely, to be largely accounted for by profound overturned folds whose tops have been truncated by erosion, and the faulting, some of which may be of the overthrust type, may also be a factor that enters into the present structural attitudes of the schists to an extent that can not be defined without detailed study.

As a rule the longer dimensions of the intrusive rock bodies follow more or less closely the general structural trends of the schists that contain them, whether they occur as large masses, some of which are several miles .wide and 5 to 15 miles or more long, or as much narrower dike-like bodies. Many of these intrusive rocks, both the massive and the dike-like forms, show strongly developed shear and joint fracturing, and in some places they have suffered metamorphic alteration to the extent of assuming gneissoid structure, especially along the margins of the larger granitic masses. Locally considerable bodies of the granitic rocks are gneissoid throughout.

\section{MINERALIZATION.}

In general the transformations that have taken place in the mineral constitution of the Birch Creek schist are of the kind that have affected, over widespread areas in greater or lesser degree, all the members comprising the formation. The present condition of the rocks is the result of what is called regional metamorphism, in distinction to the similar mineral alteration termed contact metamorphism, which is not only of much less areal extent but is confined to narrow zones along the immediate contacts of intrusive rocks with country rocks.

Although the Birch Creek schist is made up of rocks that resulted primarily from regional metamorphism, it has also been affected secondarily by a minor amount of contact metamorphism. The contactmetamorphic effects are most evident in connection with granitic intrusives, which evidently entered the country rocks after they had become transformed partly, if not wholly, to a schistose condition. In fact, the occurrence of contact-metamorphic alteration about the borders of these intrusive rocks constitutes the principal evidence as to the relative time when the granitic rocks were intruded and when the mineralization they stimulated took place. But even this evidence is far from conclusive, for at many localities the problem of determining when the intrusion and its accompanying contact mineralization occurred is complicated by the fact that some of the granitic rocks also have suffered metamorphism since they were intruded, as is shown by their gneissoid or schistose structure. These diverse conditions throughout the two schist belts under consideration make it im- 
possible to state whether the intrusion of all the granitic rocks and the resulting contact mineralization took place at the same time and the rocks were subsequently affected by further metamorphism that was more intense in some localities or rocks than in others, or whether the granitic rocks were intruded at different times throughout the long period of general regional metamorphism and for this reason show different degrees of alteration. This question apparently has an intimate relation with the origin of at least some of the gold, for in some places the gold-bearing mineralization seems to be directly connected with the effects of igneous contact alteration. At other localities, however, such a relation, if it originally existed, has been so obliterated by further metamorphism as not to be evident.

One of the most common and easily observed changes that occurs in the metamorphism of rocks, whether of the widespread regional or more localized contact character, is the rearrangement and redistribution in various forms of the silica or quartz contained in the original rocks before they became altered and in such intrusive rocks as may become associated with them before, during, or after their transformation. Not only may the quartz be changed from its original condition and form by recrystallization in place or nearly in place in the parent rock matrix, but large amounts of it may become dissolved in circulating waters which may contain also mixtures of other minerals in solution. These mineralized solutions may migrate through the country rocks, perhaps for considerable distances, and be redeposited elsewhere in various forms as secondary quartz, the term secondary being used in the sense that the quartz has changed from its primary condition with reference to its original position or mode of occurrence in the rocks of which it is a constituent.

Secondary quartz is the most common and widespread gangue or cementing material found in rocks that have been disrupted and otherwise deformed by geologic forces. The manner and form of the changes and migrations the quartz undergoes in being deposited secondarily depend on the chemical nature and physical condition of the rocks through which and into which it circulates in liquid form. The quantity of quartz thus deposited is far greater than that of any other mineral. Generalized estimates indicate that under favorable conditions probably 90 per cent or more of all the openings, both large and small, produced in rocks by metamorphic deformationsuch as faults, fissures, joints, bedding partings, and the minute spaces between laminæ, grains, and the smallest particles that compose the rocks, whether they are the result of fracture, flexure, flowage, or simply the natural porosity of some beds-become infiltrated or filled by a cement of quartz. Generally the quartz assumes the forms of the spaces it occupies. These vary according to the kinds and conditions of the rocks. The coarser-grained, more rigid rocks 
usually have larger, more regularly disposed, and continuous cleancut openings or fractures, along which veins of considerable size are deposited. The finer-grained, less rigid rocks present spaces of irregular size and shape which may have a disordered arrangement, suggesting that they have been kneaded. In these the secondary quartz usually tends to follow the schistosity of the country rocks as small contorted and twisted veins and lenticular bodies, some of which may be of considerable size, with knotty bunches and smaller crosscutting veins and leaflets disseminated between them, which for the most part are irregularly disposed and somewhat disconnected. Where a series of schists is made up of alternating harder and softer members, like the Birch Creek schist, the rocks are usually fractured in the former and flexured in the latter, and as a consequence the secondary quartz generally shows the differences in manner of deposition noted above. A great variety of both these modes of deposition of secondary quartz, with all possible intergradations from one to the other, is characteristic of the Birch Creek schist as it occurs in the Hodzana highland area and in the Koyukuk and Chandalar districts.

Where dissolved metallic minerals become mixed with solutions of quartz they generally solidify in more or less close association with the quartz, where it is redeposited under favorable conditions. Gold, both in its native state and in association or combination with metallic minerals, such as the sulphides of iron, silver, arsenic, and lead, occurs in many places with secondary quartz thus redeposited from solutions. The quartz either wholly or partly fills the spaces in the rocks, and if metalliferous compounds are present they are generally deposited also, either intermingled with the quartz or closely associated with it.

In the Chandalar district, where gold-bearing quartz deposits of importance are known to occur within a small area at the source of Big Creek, it seems to be evident that the gold is connected with veins of quartz in zones of contact alteration surrounding or connecting bodies of dioritic intrusive rocks. In the Koyukuk district the close genetic relationship of the gold to contact mineralization is not so apparent, but some intrusive dioritic rocks are known to occur there (see pp. 42-43), and more detailed examination may show that the bedrock source of the gold is closely connected with zones of contact alteration.

\section{PALEOZOIC ROCKS.}

SUBDIVISIONS.

There are two groups of rocks in this region which, though with little doubt of Paleozoic age, can not now be assigned definitely to any period in that era. Even the relative age of one compared with the 
other can not be stated with any satisfaction. They are quite different lithologically and are not known to occur in contact with each other in the region under consideration. One of these groups is made up largely of massive crystalline limestones. The possibility of its being either upper Silurian or lower Carboniferous has been suggested, but at present the lower Carboniferous age of these limestones seems to have more evidence in favor of it. The other group, which may be of Devonian age, comprises a series of cherts and slates with some dark fine-textured quartzites and a few thin beds of limestone, together with compact greenstones, fine-grained pyroclastic roeks, basalts, and intrusive diorites.

\section{DEVONIAN (?) ROCKS.}

\section{Character and Distribution.}

Mendenhall ${ }^{1}$ has described a complex of volcanic rocks, which occurs in the southwestern part of this region, under the name Kanuti series. This complex is made up of greenstones, pyroclastic rocks, basalts, a large amount of intrusive diorites, and some hornstones or dense flinty shales, the whole series being intruded by granites.

Rocks of a somewhat similar character occur on Yukon River at the southern boundary of the region under discussion. These rocks, which have been studied by Prindle, ${ }^{2}$ are made up of greenstones of various types, chiefly volcanic, together with slates, cherts, and limestones. Some volcanic rocks, cherts, and slates seen by the writer on the South Fork of the Koyukuk and between the South Fork and Slate Creek are provisionally correlated with this group, as are also somewhat similar rocks along the west side of Chandalar River between its West Fork and Crooked Creek, named by Schrader ${ }^{3}$ the West Fork series. This series consists of fine-grained quartzite, dark flint, calcareous black shale, and impure limestone, intruded by dioritic and greenish diabasic dikes that follow the structure of the country rock, which trends from northeast to southwest. It forms the bedrock of the broad area between West Fork and Crooked Creek and the rolling divide about their sources 12 to 15 miles west of the Chandalar. This belt, which is about 15 miles wide, corresponds with the broad depression that lies between the Hodzana highland on the south and the southern flanks of the Endicott Mountains on the north and extends westward from the lower Chandalar Valley to that of the Middle Fork of the Koyukuk.

1 Mendenhall, W. C., Reconnaissance from Fort Hamlin to Kotzebue Sound, Alaska: Prof. Paper U. S. Geol. Survey No. 10, 1902, pp. 37-38.

Prindle, L. M., The Fairbanks and Rampart quadrangles, Yukon-Tanana region, Alaska : Bull. U. S. Geol. Survey No. 337, 1908, pp. 18-22.

3 Schrader, F. C., Preliminary report on a reconnaissance along the Chandlar and Koyukuk rlvers, Alaska, in 1899 : Twenty-first Ann. Rept. U. S. Geol. Survej, pt. 2, 1900, pp. $475-476$. 
Schrader considered that these rocks extended westward and southwestward to the Middle Fork of the Koyukuk in the low mountains 5 to 10 miles south of Slate Creek and on the South Fork of the Koyukuk in the vicinity of Jim River, where they have been observed by the writer. He also suggested their probable eastward extension to the East Fork of the Chandalar and possibly to Porcupine River, where a series of shales, limestones, and diabase occurs in the lower part of the Upper Ramparts.

The facts at hand do not warrant any definite statement in regard to the structure of these rocks, except that they are considerably deformed and much fractured. Some quartz veins occur in the fracture spaces, and they may be locally mineralized, but so far as known they have yielded no deposits of value.

\section{AGE AND CORRELATION.}

There is no direct evidence regarding the age of this assemblage of rocks. They are apparently in unconformable relations with the Birch Creek schist. Schrader found a few fossils referable to the Devonian in gravels and cobbles along Chandalar River and the South Fork of the Koyukuk, which on the basis of their lithologic similarity to beds in his West Fork series he considered to be derived from that source. Mendenhall correlated his Kanuti series with Spurr's Rampart series and provisionally assigned them to the middle of the Paleozoic. A few fragmentary fossils from rocks of this general group on the middle Yukon in the area here under discussion belong at the same general horizon. On the upper Yukon between Eagle and the Yukon Flats volcanic greenstones, some of which are interbedded with and all of which are more or less closely associated with shales and limestones, are in close stratigraphic relation with Middle Devonian limestones. There is a similar association of Middle Devonian limestones with greenstone volcanic rocks and shales on Porcupine River in the lower part of its Upper Ramparts. Altogether the assemblage of rocks with these general characters and interrelations appears to have a widespread development throughout the central Yukon Valley, and wherever paleontologic evidence has been found it points toward the Devonian age of the rocks.

CARBONIFEROUS (?) ROCKS.

IITHOLOGY, STRUCTURE, AND DISTRIBUTION.

The northwestern part of the area under consideration is almost wholly occupied by a series of massive semicrystalline and crystalline limestones interbedded with some mica schists. The limestone is much jointed and in many places very schistose. Many of the fractures have been filled with calcite and some of them with quartz, and 
a few of these were observed which contain pyrite, chalcopyrite, or galena. In general, however, the rocks do not seem to be mineralized. Their usual color is light gray or dingy marble-white, but they include also darker members, and here and there extensive exposures stained iron-red and brown are conspicuous.

As a whole they seem to be thrown up into a number of folds whose axes run about east and west. Schrader found evidence of strong fault displacements in the limestone, which seems to account for some of the peculiarities of distribution of these rocks in the northern part of the field and for their generally rugged forms and the steep scarps which form very conspicuous topographic features in many places. (See Pl. VI, $B$, p. 34.) Considerable faulting has occurred along their southern border, where they are in contact with the KoyukukChandalar belt of Birch Creek schist, which passes beneath the limestones. The limestones may be overthrust upon the schist.

So far as known these limestones make up practically all the central ranges of the Endicott Mountain belt. Within the area covered by the map ( $\mathrm{Pl} . \mathrm{V}$, in pocket) their somewhat irregular southerı boundary is seen to extend from the upper Chandalar, whose valley they cross about 35 miles above Chandalar Lake, southwestward along the northwest slopes of the valleys of Robert Creek and Bettles River to Dietrich River. Here there is a conspicuous isolated outlying mass between the lower 5 miles of Bettles River on the east and the upper 5 miles of the Middle Fork of the Koyukuk on the west. (See Pl. VI, B, p. 34.) The boundary of the main body of limestone extends northward from lower Bettles River along the east slopes of the valley of Dietrich River for about 20 miles and then crosses to the west side of the valley. (See PI. VI, $A$, p. 34.) Thence the limestones extend southwestward for about 80 miles in a belt of irregular outline to John River, which they cross about 40 miles from its confluence with the Middle Fork of the Koyukuk.

\section{AGE AND CORRELATION.}

Schrader ${ }^{1}$ first described these limestones and associated schists under the name Bettles series, but did not assign them to any definite place in the stratigraphic column. Later he described, under the name Skajit formation, ${ }^{2}$ a belt of limestones about 20 miles wide on John River, which because of their resemblance to the schistose, crystalline, and micaceous phase of the Bettles "series" are provisionally correlated with that series. Some poorly preserved fossils collected

\footnotetext{
${ }^{1}$ Schrader, F. C., Preliminary report on a reconnaissance along the Chandlar and Koyukuk rivers, Alaskn, in 1899: Twenty-first Ann. Rept. U. S. Geol. Survey, pt. 2, 1900, p. 475 .

Schrader, F. C., A reconnaissance in northern Alaska: Prof. Paper U. S. Geol. Survey No. 20,1804 , pp. 56-58.
} 
from the Skajit formation in place include the remains of a brachiopod, which indicates an age not older than upper Silurian and not younger than lower Carboniferous.

These limestones are certainly younger than the Birch Creek schist and presumably are the equivalent of at least one or possibly more of the Paleozoic limestones of the Yukon Valley. Of these there are four-the Ordovician, Silurian, Devonian, and Carboniferous. East of the Koyukuk-Chandalar region, along Porcupine River, all four of these geologic systems are represented, the stratigraphic position of the limestones having been well established by the fossils they contain. Across the one hundred and forty-first meridian of west longitude, from 50 to 100 miles north of Porcupine River, along what is generally considered to be the eastward extension of the Endicott Mountains, there are widespread limestones of lower Carboniferous age overlying an extensive series of quartzites and slates which if more thoroughly metamorphosed could easily be the counterpart of at least a portion of the Birch Creek schist of the Koyukuk-Chandalar region. The Ordovician, Silurian, and Devonian limestones that occur along Porcupine River are apparently absent to the north, in this area. To the west, in the lower and central portions of the Noatak Valley, occurs a series of limestones that is definitely known to be of Carboniferous age, and in the upper Noatak, Kobuk, and Alatna valleys limestones which may be of this general age occupy wide areas. The age of these limestones may be the same as that of the Skajit formation on John River and of the Bettles "series," which crosses the upper Koyukuk and Chandalar basins. It may be that the undifferentiated limestones of the upper Noatak, Kobuk, and AIatna valleys, which have a strong resemblance to the Skajit formation, and which in turn may be the same as the Bettles "series," are not only equivalent but of Carboniferous age. At least, for the present there can be no objection to entertaining this tentative correlation.

\section{MESOZOIC ROCKS.}

GENERAL FEATURES.

Sedimentary formations of Mesozoic age do not cover extensive or widely distributed areas in the Koyukuk-Chandalar region. The only sediments definitely assigned to this era are of Cretaceous age and occupy but a small part of the region, being confined to the northeastern part of the central Koyukuk Valley. (See Pl. V, in pocket.) With these sediments are included some basic effusive and pyroclastic rocks that are apparently more or less interbedded with the stratified deposits and are for this reason presumed to be of the same age. 
In addition to the Cretaceous sedimentary and basic effusive igneous rocks, practically all the acidic intrusive granitic rocks of the Koyukuk-Chandalar region, which are especially abundant in some parts of the Birch Creek schist belts, as already noted, are considered to have been intruded into the country rocks during Mesozoic time.

\section{CRETACEOUS SYSTEM.}

CHARACTER, STBUCTURE, AND DISTRIBUTION.

The unaltered stratified formations of the Koyukuk Valley consist of limestones, sandstones of calcareous, feldspathic, and quartzitic composition, conglomerates, and shales, with some basic igneous effusive and pyroclastic rocks. The feldspathic sandstones or arkoses appear to be characteristic of the lower part of the series and, together with some conglomerates that are probably at or near the base of the series, overlap on the older schistose rocks of the southern foothills of the Endicott Mountains where they meet them along the northern margin of the upper basin of the valley. The limestones appear to characterize the upper part of the series.

All these stratified rocks have been folded and somewhat faulted. The folding is more pronounced at some localities than at others. In some areas the beds are quite horizontal; in others they stand at steep angles. As a whole, however, they have been disturbed far less than the Paleozoic rocks and schists, to which they bear an unconformable relation.

These sedimentary formations occupy the southwestern part of the Koyukuk-Chandalar region and represent the margin of an extensive sheet of Mesozoic sediments which extends south, southwest, and west from the central Koyukuk Valley to Yukon River and Norton Bay. In the Koyukuk Valley they make up practically all the interstream uplands and minor mountain groups between the lower courses of the principal large headwater tributaries of the Koyukuk and the bedrock bluff's along the main river, except in a few places where the older underlying rocks crop out from beneath them.

\section{AGE AND CORRELATION.}

The rocks described above have been divided by Schrader ${ }^{1}$ into two conformable groups - a lower group, which he named the Koyukuk series, and an upper one, which he called the Bergman series. The lower group contains the marine limestones already noted, which have yielded Lower Cretaceous or Upper Jurassic fossils. The upper or Bergman group, which in part, at least, appears not to be marine and to which the coal beds at Tramway Bar, on the Koyukuk, may belong, has been considered by Schrader to be in-

${ }^{1}$ Schrader, F. C., A reconnalssance in northern Alaska : Prot. Paper O. 8. Geol. Surveg No. 20, 1904, pp. 77-79. 
folded and closely related with the Koyukuk group, but to be younger and overlie it. To the south, along Yukon River, sediments of this general character carry both marine and plant fossil remains of late Mesozoic and early Tertiary age which indicate that they were laid down during a period of transition from Mesozoic to Tertiary time, when there was no apparent pause or depositional break in the geologic sequence. For present purposes both the marine and nonmarine groups have been mapped together as Cretaceous.

\section{MESOZOIC (?) INTRUSIVE ROCKS.}

The intrusive rocks of the region include granites, granodiorites, diorite, and diabase. All these rocks except the diabase and some of the diorite probably belong to one general epoch of intrusion. Some of the granitic rocks are gneissoid and may be older than the Mesozoic. As has already been said (p. 37), there is no direct evidence of the age of any of these intrusive rocks, though they are - known to be, in part at least, younger than the volcanic rocks described in connection with the rocks of probable Devonian age (p. 50), and are probably older than the Mesozoic sediments which have been assigned to the Cretaceous. These igneous rocks, except the diabase, are here assigned to the Mesozoic because that is known to be the era of most widespread intrusive igneous activity throughout Alaska. Moreover, they resemble the known Mesozoic intrusive rocks of other parts of the Territory. Schrader ${ }^{1}$ has noted the presence of diorite dikes in the Cretaceous sediments of the middle Koyukuk Valley. It seems probable that some of the diorites or granites may be of later age than the Cretaceous.

Because of the occurrence of rocks of intermediate composition no sharp line can be drawn between the granites and the diorites. The diorites differ from the granites in the predominance of plagioclase feldspars, the subordination of quartz, and the substitution of hornblende for mica. Quartz diorites or granodiorites, of intermediate composition between the diorites and granites, are not uncommon. In the large masses the rock is generally of granular texture, but porphyritic phases occur both within and around the margins of the larger intrusive masses and also in the dikes and small stocks.

On the middle Chandalar and elsewhere in the region some of these intrusive rocks are gneissoid. These are sheared and crushed igneous rocks consisting of quartz, feldspar, mica, and hornblende, with chlorite abundantly developed as a secondary product, giving the rocks a greenish color. They may represent an older epoch of injection than that of the less altered, more massive igneous rocks.

\footnotetext{
1 Schrader, F. C., A reconnalssance In northern Alaska:-Prof. Paper U. S. Geol. Sur.
} vey No. 20, 1004, p. 77. 
Among the rocks not included in the foregoing description are some aplite dikes and veins which cut the granites in a few places and probably represent the last stages of igneous activity.

The areal distribution of these intrusive rocks needs no special discussion, as it is shown on the map. Attention may, however, be called to the extensive masses of granite and diorite which occur in association with the Birch Creek schist of the Hodzana highland belt, between the Chandalar and the Koyukuk. Granitic and dioritic rocks also occur in other parts of the field (see pp. 41-43), in addition to which there are many dikes that are unmapped.

\section{CENOZOIC ROCKS.}

\section{TERTIARY SYSTEM.}

The sedimentary rocks which may with reasonable certainty be assigned to the Tertiary period are known to occur at one locality in the area under consideration. These occupy a very small area (see Pl. V, in pocket) in the upper basin of Dall River, on and near the lower part of a west-side tributary named Coal Creek. They comprise soft gray, buff, or black shales, standing at an angle of about $30^{\circ}$ and associated with a heavy bed of lignitic coal and bone. No fossil plant remains have been found in these beds, but because of their lithologic resemblance to well-determined strata in other parts of the Territory, they are considered to belong to the group of Tertiary lignite deposits.

On the Middle Fork of the Koyukuk about 12 miles below Coldfoot the older rocks on the north give way to a series of younger sediments composed of sandstones, grits, and shales, with conglomerates and at least one bed of coal. Schrader, ${ }^{1}$ who observed these beds, first considered them to be of Tertiary age, but in a later report ${ }^{2}$ named what appear to be the same sediments to the west, on John River, the Bergman "series" (see p. 54) and provisionally referred them to the Cretaceous.

More detailed surveys of this region may disclose other areas of 'Tertiary sedimentary rocks, some of which may be coal-bearing.

\section{CENOZOIC LAVAS (TERTIARY OR QUATERNARY).}

Two areas of lavas which may be of Tertiary age are known in this region, one on Kanuti River and the other on Chandalar River. Mendenhall ${ }^{3}$ has described the Kanuti River area as follows:

1 Schrader, F. C., Preliminary report on a reconnalssance along the Chandlar and Koyukuk rivers, Alaska, In 1899 : Twenty-first Ann. Rept. U. S. Geol. Survey, pt. 2, 1900, p. 477.

'Schrader, F. C., A reconnaissance in northern Alaska: Prof. Paper U. S. Geol. Survey No. 20,1904 , pp. $77-79$.

3 Mendenhall, W. C., Reconnaissance from Fort Famlin to Kotzebue Sound : Prof. Paper C. S. Geol. Survey No. 10, 1902, pp. $42-43$. 
Basalt.-Along the mlddle Kanuti River horizontally bedded vesicular olivine basalts form bluffs 50 to 75 feet high on the north bank of the river, and similar bluffs south of the valley are probaby due to the same formation.

Andesites and tuffs.-The most extensively distributed lavas in the Kanuti River valley are hornblende-andesites and associated fragmental material. They are composed of massive flows and coarse brecclas, the latter sometimes containing angular blocks 10 feet in diameter, embedded in fine ash or pumice. They form bluffs 250 feet in height along the river. Downstream from this locality the tuffaceous form of the deposit disappears, but the low hills for many miles north of the river are made up entirely of massive andesites.

Age.-The basalts and andesites were not found in contact, but both occur along the Kanuti River in horizontally bedded flows. The andesites lie at higher levels and are therefore perhaps younger. Since both are structurally undisturbed, they are more recent than the Tertiary lignite-bearing beds of the upper Dall River, which are extensively folded. The relation of the andesites to the topography is such as to suggest that the lavas flowed into valleys which had been cut to approximately their present depth, and this brought about changes in drainage. The streams have since cut through or at least well into the lava and breccia filling and have removed in some cases hundreds of . feet of it. This cutting may have occupied all of Pleistocene time but probably not more, so that the lavas are to be regarded as very late Tertiary or possibly early Pleistocene.

On the south bank of Chandalar River from 60 to 65 miles above its mouth, at the point where it enters the Yukon Flats, there is an area occupied by dark olivine basalts. They are principally amygdaloidal, and in part very coarsely porous and weather to a reddish or rusty brown, but they include some layers of more dense texture which usually have a fresh dark iron or steel color. Their attitude is not well exposed, but they appear to have a typical lava flow structure and to consist of superimposed members several feet in thickness. Their topographic expression is that of a plateau or flat-topped bench whose highest parts stand about 1,000 feet above the river. It is not thought that their thickness is as great as 1,000 feet, however, for to the west, about a mile above the East Fork, the lavas are succeeded by gneissoid granitic rocks which are undoubtedly older, and to judge from the talus along the valley slopes opposite and east of the mouth of East Fork the gneissoid rock appears to extend in this direction for several miles as the basement upon which the lavas rest, although the contact of the two has not been observed. The lavas are best exposed in a few bluff faces overlooking the river near the upper edge or break of their benchlike surface. The margins of this bench are not much rounded and are for the most part merely notched here and there by erosion.

The areal extent of these basalts is not known, but if they are the capping formation of the benchlike feature which characterizes each side of the Chandalar Valley, where it opens out into the Yukon Flats, they may extend southwestward for a considerable distance and they may occur on the north side of the valley also. 
These basalts, like those on Kanuti River, are provisionally considered to be of late Tertiary or early Pleistocene age.

\section{QUATERNARY SYSTEM.}

PLEISTOCENE SERIES.

SEDIMENTS.

Extensive deposits of unconsolidated sediments, which for the most part seem to be stream laid, occur along the southern foothills or flanks of the Endicott Mountains and extend southward from them as thick and widespread fillings along all the main drainage courses of the region and also extend across the lower divides from one drainage basin to another. They are without doubt contemporaneous throughout the region and are the result of a system of drainage that was quite different from that of to-day. They are composed of gravels, sands, and silts, and although they show considerable variation in coarseness, their predominant characteristics are that they have been transported, assorted, and deposited by flowing water and appear to be in large part glacial débris or detrital materials which have been vigorously outwashed from the mountains to the north.

The upper South Fork and Mosquito Creek basins are practically filled with these more or less assorted outwash deposits of gravels, silts, and bowlders and they also occupy a wide expanse west and northwest from South Fork for 15 miles to the Middle Fork of the Koyukuk, and beyond, down the valley of that river. From north to south across this area the width of these unconsolidated deposits is about 10 miles. . Their general surface appears to slope both from east to west and from north to south. Their highest margin is along the base of the mountains on the north, where they stand at about 2,000 feet, but they seem to descend gradually from east to west to a general elevation of 1,500 feet on the Middle Fork at Tramway Bar. They also slope gradually from north to south at about the same grade, their elevation along the banks of the South Fork 20 miles below the mouth of Mosquito Creek being about 1,500 feet above sea level. However, there are remnants of gravel benches on the mountain slopes south of South Fork which indicate that a former surface of these deposits may have had an even more gentle descent across this area from north to south than the present slope and that the present surface may be due in great part to removal by erosion along the South Fork of a very large quantity of the unconsolidated filling. Likewise erosion by the present streams is, no doubt, the agency that has lowered the surface of these deposits along the Middle Fork.

In fact, the occurrence of these deposits on terraces throughout all the large valleys of the region admits of no other interpretation, for 


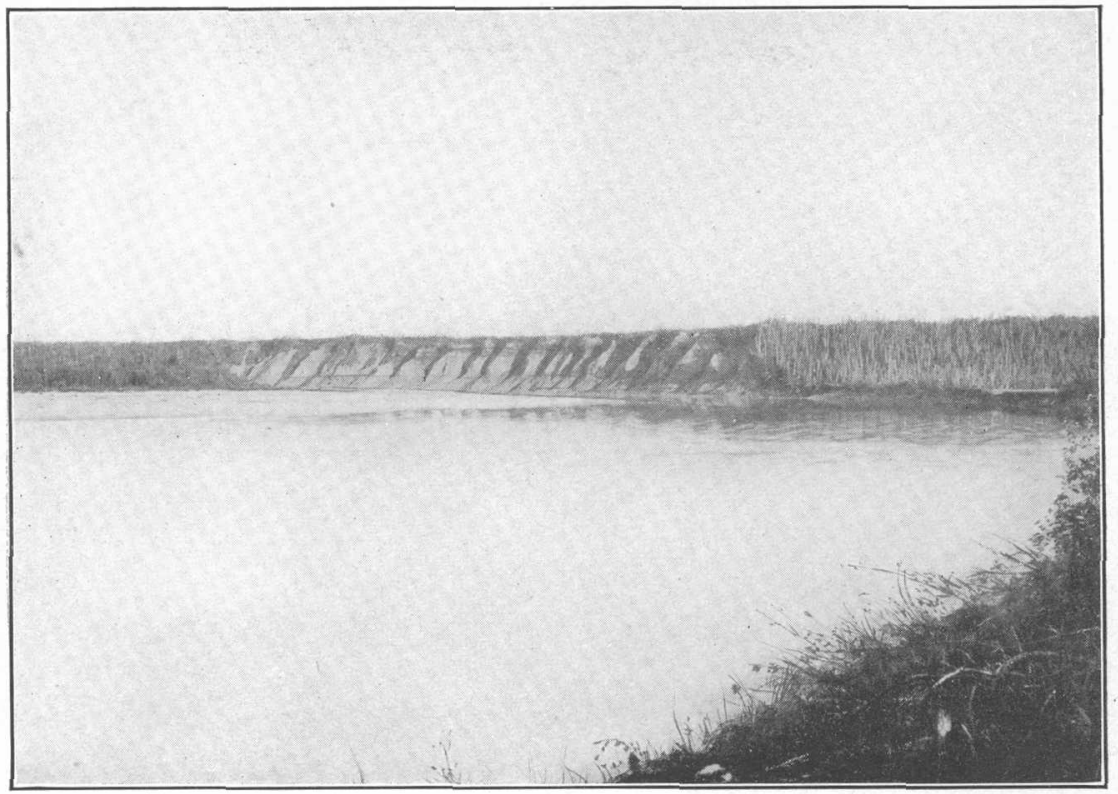

A. PLEISTOCENE SILT BLUfFS ON KOYUKUK RIVER NEAR ARCTIC CIRCLE.

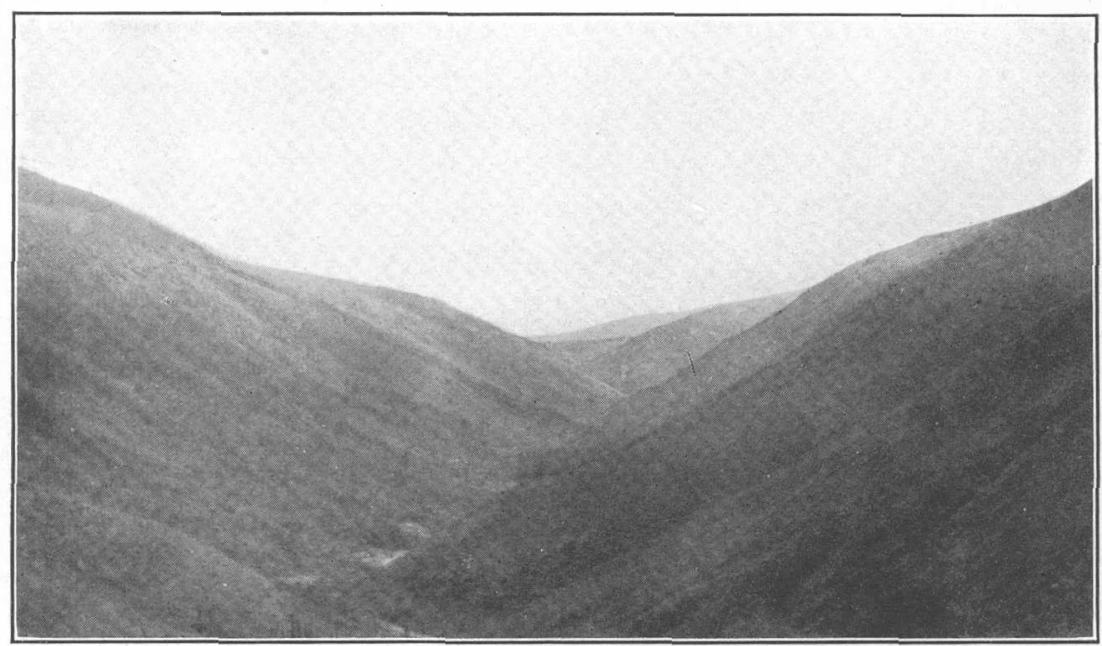

B. GOLD CREEK VALLEY NEAR MOUTH.

Looking upstream from top of canyon. Shoulders indicate old valley-floor level, now dissected by recent $V$-shaped valley. 
these terraces evidently indicate the elevation and extent of the former flood plain upon which the sediments of the terraces were deposited. It seems that the drainage system which transported and aggraded these unconsolidated sediments over such wide areas must have been of a different character from that of to-day. (See pp.60-67.)

The present drainage has not only removed a large quantity of the unconsolidated filling and thus lowered and modified its surface and left its marginal portions as terraces or benches, but recently at least its major channels have entrenched themselves into the unconsolidated deposits locally to depths of 100 to 200 feet, and at places into the harder underlying country rocks as well. By far the largest part of the deposits, however, still remain on terraces or sloping benches which extend far up the sides of the valleys and across the low divides that separate many of the lateral tributaries which drain the foothills. These bench deposits are especially to be noted between the Middle and South forks of the Koyukuk from the vicinity of Slate Creek and Tramway Bar eastward, as has been described, and also from the South Fork, by way of Mosquito Creek, to west-side tributaries of the Chandalar named Crooked Creek and West Fork, where the gravels and silts extend across divides that stand at elevations of 2,350 feet.

They occur on extensively developed terraces along the North, Middle, and East forks of the Chandalar and are continuous with similar deposits along the main river that extend downstream to the northern margin of the Yukon Flats, where the highest terraces stand at elevations of about 1,500 feet above sea level. Likewise they extend southward along the valleys of the Middle Fork and main Koyukuk (Pl. VII, $A$ ) to the northern edge of the Koyukuls Flats, where they merge with the marginal basin deposits at an elevation of about 1,500 feet, about the same as those of the Yukon Flats.

The terrace deposits along the south front of the Endicott Mountains extend northward up the-main valleys within the mountains, decreasing in lateral extent as the valleys become narrower and increase in elevation. On the Middle Fork of the Koyukuk at the mouth of Wiseman Creek they stand at an elevation of about 2,500 feet and farther north, within the mountains, they rise to about 3,000 feet on upper Bettles and Dietrich rivers.

Near the mountains the deposits contain glacial bowlders, and these are more numerous within the mountain valleys, where, in general, the deposits bear more resemblance to a glacial valley filling, as they contain much coarser material which in places does not show marked assortment or arrangement by running water. There are also scattered patches of what appears to be glacial till and a few bowlder trains that have a morainal aspect. In general the coarser materials are characteristic of the mountainous part of the region, 
while to the south, beyond the mountains, the deposits are more commonly composed of fine silts.

What has just been said in regard to the Middle Fork within the Endicott Mountains applies also to the other branches of the Koyukuk and to the Chandalar and its principal tributaries. For example, these deposits stand at an elevation of approximately 3,000 feet in the depression drained by Lake and Grave creeks, and gradually descend and coalesce with the terrace deposits of the North and Middle forks of the Chandalar.

These terrace deposits were wholly or in large part intimately associated with the retreat of glacial ice and can probably be best classed as outwash deposits. Whether the silt deposits of the Yukon and Koyukuk flats are also of glacial origin has not been definitely determined. They may be in part, at least, of such derivation.

In several localities, notably at Tramway Bar on the Middle Fork and Gold Bench on the South Fork of the Koyukuk, gold-bearing gravels are closely associated with the terrace deposits. These gravèls, however, are probably of local origin, as will be described under gold placers (pp. 85, 106). The nature of the terrace gravels does not seem to favor the probability of their being gold-bearing except where they have been locally reconcentrated since their deposition, and even so only where there are sources near by from which the gold might be derived.

All the unconsolidated sediments which occur in terraces or sloping benches above the flood plains of the present streams together with the glacial till and morainic deposits within the mountains of the northern part of the region, are considered to be of Pleistocene age.

GLACIATION.

The Endicott Mountain belt bears every evidence of having been subjected very recently to the erosion of glaciers across its entire width of 80 to 100 miles. To judge from the form, length and arrangement of the present valleys which dissect the mountains across their trend and which appear to owe their present deep, narrow forms largely to the erosion of ice streams, it seems that the dividing line from which the former glaciers moved to the north and south was along a zone of maximum snow accumulation whose position corresponded to the present Arctic-Yukon watershed, which lies nearer to the northern flanks of the mountain belt than to its southern flanks, and that the southward-flowing ice streams were probably longer, at least within the mountains, than those that moved northward. By far the largest part of this mountainous belt has not yet been explored. From the meager data at hand it is impossible at this time to present a satisfactory discussion of the glaciation of this part of Alaska. 
Schrader is the only observer who has described the extent and character of glacial erosion and deposition along a section that crosses these mountains. His observations were made from the Koyukuk Valley to the Arctic coastal plain by way of John and Anaktuvuk rivers, along the western edge of the area now under consideration. In a concluding paragraph ${ }^{1}$ he summarizes as follows:

The glacial phenomena that have been described tend to show that, although the Endicott Mountains do not on the whole seem to have been overridden en masse by a moving ice sheet, they were doubtless, especially in their northern part, largely occupied by an ice cap or perennial névé, constituting a breeding ground for glaciers. The zone of maximum snowfall, and consequently of maximum ice accumulation, trending in an east-west direction, was apparently in the northern part of the range, at least somewhat north of its median line. From this zone the ice moved off to the north and to the south, respectively, into the Colville and Koyuluk basins. Its flowage, especially during the latter part of the ice age, was confined mainly to the valleys and drainage ways in the form of alpine glaciers, of which there is ample evidence. But there is also good reason to believe, as shown by the till sheet north of the mountains, that during the zenith of the ice age the northern edge of the range was occupied by a more or less extensive ice sheet, which, as a small regional or piedmont glacier, thinning out toward the north, extended northward over a considerable portion of the Anaktuvuk Plateau, its occurrence at that time being, perhaps, similar to that of the Bering and Malaspina glaciers of to-day [on the Pacific seaboard of Alaska].

It is presumed that the glaciation of the Endicott Mountains eastward from John and Anaktuvuk rivers, where Schrader observed its results, was similar throughout that part of the region occupied by the headwaters of Koyukuk and Chandalar rivers. It is known. that on the sources of Canning River, which lies opposite the upper East Fork of Chandalar River, a few small mountain valley glaciers still exist, and that farther eastward, about 50 to 75 miles west of the 141st meridian, a group of mountains from 8,000 to 9,000 feet high carry some large glaciers. From the presence of these ice bodies it seems fair to surmise that glaciers of considerable extent remained in these mountains up to comparatively recent time.

At the time of the maximum development of the ice the glaciers which occupied the larger valleys evidently extended for some distance from the mountain front both to the north and to the south. On the north front of the Endicott Mountains, along the rims of the Anaktuvuk Valley, where it cuts across the Anaktuvuk Plateau, Schrader found evidence that the ice overflowed the valley and spread out over the plateau as piedmont ice sheets. This plateau surface, as it extends east and west along the front of the mountains between the larger valleys which cross it from south to north, was evidently overridden by an ice sheet that apparently completely

1 Schrader, F. C., A reconnalssance in northern Alaska: Prof. Paper U. S. Geol. Survey No. 20,1904, p. 91. 
covered the interstream areas. At least unconsolidated deposits of glacial drift are spread over this surface as a more or less continuous covering up to elevations of 2,500 to 2,600 feet above sea level.

On the south front of the Endicott Mountains in the KoyukukChandalar region there are no pronounced physiographic interstream features corresponding to the Anaktuvuk Plateau. There is, however, a broad, flat divide between the upper South Fork of Koyukuk River and the Chandalar whose highest parts stand at about the same elevation, 2,500 to 2,600 feet, as the surface of the Anaktuvuk Plateau, and deposits of glacial débris occur on this divide. These deposits of glacial detritus extend southward from the mountain front for about 15 miles, or to the northern edge of the Hodzana highland, and it appears that they were laid down there by a piedmont ice sheet which probably covered the whole area from east to west between large valley glaciers that moved out from the mountains along the present courses of the Chandalar and the Middle Fork of the Koyukuk.

Schrader ${ }^{1}$ considers that the ice mass which evidently occupied the Koyukuk Valley may have extended as far south as the mouth of Kanuti River, or about 50 miles from the mountain front. The evidence he cites in support of this view is that the Koyukuk Valley region exhibits a generally rounded topography, suggestive of former glaciation, up to a height of 1,600 or 1,800 feet; that till-like deposits occur near the mouth of John River and on the west bank of the Koyukuk between Bettles and the mouth of Jane Creek, where they form bluffs about 100 feet high; that on the northeast side of the lower Alatna Valley what seem to be till terraces occur along the south side of Double Mountain up to a height of 1,600 feet; that just below the mouth of Alatna River there is a steep-faced exposure of clay and gravel, standing from 80 to 100 feet above the river, the lower 50 feet of which seems to be glacial till; and that from the character of the topography glacial drift is suspected to occur along the east bank of the Koyukuk southward from the Alatna toward the mouth of Kanuti River.

From the above-enumerated observations in this part of the field it is inferred that glaciation extended from the Endicott Mountains southward into the Koyukuk basin across the Arctic Circle and beyond Bergman.

In that part of the Chandalar Valley which borders the northeastern margin of the Hodzana highland from the Yukon Flats to the West Fork there occurs a more or less continuous series of terraces and sloping benches of unconsolidated Pleistocene deposits which form bluffs along the river 100 feet high. Schrader considered

\footnotetext{
1 Schrader, F. C., A reconnalssance In northern Alaska : Prof. Paper U. 8. Geol. Survey No. 20, 1904, p. 89 .
} 
some of this unconsolidated detrital material to be glacial till. $\mathrm{He}$ also observed glacial drift on the south side of this valley, opposite the mouth of Flat Creek, at a height of about 2,200 feet, approximately the height at which similar deposits occur along the north flanks of the Hodzana highland to the west. From the above meager facts it may be provisionally suggested that the Chandalar Valley was occupied by a large glacier which extended nearly, if not quite, to the northern border of the Yukon Flats.

To summarize briefly, it appears that at the time of their maximum extent glaciers extended southward along the larger valleys for some distance from the mountain front, probably at least 50 and possibly 100 miles or more, and that the areas along the mountain front within 15 or 20 miles of and between these large valley glaciers were covered by piedmont ice sheets up to an elevation of about 2,500 feet. Taking 2,500 feet as the approximate upper limit of glaciation just beyond the mountain front, it may be stated that in general the surface of the ice rose from south to north and probably had an elevation of 5,000 or 6,000 feet on the mountains along the zone of supply, in the general position of the present watershed.

Apparently all the trunk valleys across the Endicott Mountains have been modified by glacial erosion and have been more or less filled with products deposited as the glaciers wasted away and disappeared. The after effects of glaciation are shown in various ways within the mountains, principally, however, by the deposits along the valleys which have already been described ( $p p .59-60$ ). Some of the special features they present, which are of economic interest because of their association with gold-bearing gravels, will be noted.

The surface of the region is predominantly one of bold mountainous character, whose principal features are rugged ranges, with general structural trends from northeast to southwest, and deep, but comparatively narrow, steep-sided valleys cut through the mountains by the larger rivers from north to south. The bottoms of the larger valleys are from 1,500 to 2,000 feet above sea level, and from a quarter of a mile to 2 miles wide. The mountains rise boldly and in places abruptly from valley bottoms to rugged heights from 2,000 to 5,000 feet above the valleys, or 3,000 to 6,000 feet above sea level; indeed, along the major divides some peaks rise to elevations of nearly 7,000 feet.

The most marked features of the drainage are a north-south system of narrow, parallel major valleys deeply incised into the mountainous land mass, and an immaturely developed lateral drainage on the flanks of the mountain divides that separate the larger rivers. The downcutting along the larger valleys has been so rapid during the comparatively recent geologic history of this region that most of the drainage of secondary magnitude lateral to the rivers has not 
been able to extend the areas of the tributary valleys, or wear them down to the level of the principal valleys, the result being that most of the creeks on which placer mining is done are rather swift, and have steep-gulch valleys, and in many places box canyons along their courses, especially in their lower parts, just before they join the larger valleys. Much of the placer gold mined has been taken from the comparatively narrow and shallow gravel. deposits along the bottoms of these tributary valleys.

The main valleys appear to owe their present size and forms chiefly to the former presence of large, long glaciers that had their sources on the Arctic divide to the north, and extended at least to the southern flank of the Endicott Mountains. The large ice streams appear to have modified the shape of the cross sections of the main valleys by cutting away their lower slopes, and thus widening their floors somewhat and steepening them to the forms they have to-day, which are characterized by flat bottoms and abruptly rising sides. These steep sides are especially pronounced where formed by the truncated ends of the intertributary mountain spurs that are lateral to the main divides. In places these steeply truncated sides of the main valleys extend across the mouths of the tributary valleys, thus making them of the hanging-valley type. In most such places the streams in the discordant side valleys have partly cut their immediate channels down below the old floor levels of the hanging valleys, and now enter the main valleys through gorges or canyons (Pl. VII, $B$, p. 58). Other side valleys, however, enter the main valleys by wide mouths at accordant levels.

When the large glaciers disappeared by melting, they left behind considerable quantities of unconsolidated material in the form of bowlders, cobbles, gravels, and silts, which now largely cover the floors of the valleys throughout their length and width. Very little of this material is now found in the form of unassorted drift. Most of it belongs to the class of glacial deposits that have been subjected to the vigorous wearing and assorting action of swiftly running water after the glaciers retreated. Along the flat lower parts of the valleys these deposits have been well graded and now occur in the form of partly sorted cobble beds, regularly arranged gravels, coarse crossbedded sands, and fine silts and clays. They occur not only along the floors of the large valleys, but also as terraces along their sides and back into the tributary valleys that open out from the mountains. In the middle part of the Tobin Creek valley and on lower Big Creek there are thick deposits of silt and clay which appear to have been deposited in small lakes that were formed along the borders of the glaciers in the lower parts of these side valleys at a time when the main valley glaciers dammed up their mouths with high barriers of ice. Most of the silts and clays of the dammed valley deposits appear 
to have been derived from muddy glacial waters, but no doubt some of the silts may have come from the upper parts of the side valleys above the areas formerly occupied by the lakes, and also from the slopes that were above the levels of the lakes along their sides. 'Wiseman Creek, on the Koyukuk, occupies one of the best examples of these glacier-dammed and silt-filled valleys, where the silts and clays have buried older gold-bearing stream gravels and where the later drainage has not been able to remove the glacial silt and clay filling. Tobin Creek is an example of a filled valley where the present drainage has been vigorous enough to remove a large part of the clays and is now rapidly carrying away what remains. This is shown by the turbid silt-laden water of this stream from the "mud banks" to its mouth. The lake that formerly occupied the basin of Wiseman Valley was apparently drained by several comparatively sudden drops to lower levels, with longer periods of rest between the drops. During the stationary periods bench deposits, or narrow beaches, were formed on the valley slopes at the positions of the different shore lines of the lake and the gold now found in these benches along the valley sides was no doubt concentrated in them at the mouths of gulches. The gold appears to have come from the bedrock of the mountain slopes above the lakes, and no doubt much of the gold now found in the benches at the lower levels is derived from similar benches at higher levels where gold was concentrated previously.

On Tobin and Big creeks, in the Chandalar Valley, the old shore lines of the former lakes have not been traced or prospected and it is not known whether they occur at more than one level. On Wiseman Creek, in the Koyukuk Valley, the former glacial-lake shore lines are known to lie at several different levels. These have been prospected to a slight extent and the two lowest have been mined at several places along the east side of Nolan Creek. Placer gold is reported to occur on Tobin Creek, both below and above the locality where the stream is now washing away the clay deposits of the former glacial lake that occupied the lower half of its basin, but paying quantities have not yet been developed.

As a result of this varied relief and its modified forms the unconsolidated deposits of the valleys, whether gold-bearing or not, present many different features of character, position, depth, distribution, and condition. In some localities the erosion and deposition accom: plished during a former period of drainage development, which appears to have been largely the result of glacial conditions, seem to be responsible for the present nature of the placer-gold deposits, whereas at other localities glacial drainage does not appear to have effected the processes of erosion or the concentration of the gold, which appear to be such as are normal to an unglaciated moun$76032^{\circ}-$ Bull. 532-13-5 
tainous region. For example, the influence of a former glacial drainage does not appear to have extended to the part of the Chandalar district at the head of Big Creek, where most of the mining development has been carried on, nor to some of the streams in the Koyukuk district, such as the upper parts of Myrtle, Vermont, and Gold creeks. On the other hand, the valley of Wiseman Creek and its gold-producing tributary, Nolan Creek, in the Koyukuk district, appears to be an example of a preglacial valley where older goldbearing stream gravels have been buried beneath silts and clays, probably derived from po:ded muddy glacial waters, which the erosion since that time has not removed. The result is that the gold-bearing deposits of Nolan Creek are mined by means of shafts from 40 to 80 feet deep sunk through silts and clays to the buried gravels in the bottom of the bedrock valley. The placer gold in lower Hammond Creek valley appears also to occur in gravels that were deposited along the bottom of a preglacial stream bed which is now filled to the depth of 100 feet or less by later outwashed glacial sediments.

\section{RECENT SERIES.}

The sediments of Recent time include all the unconsolidated deposits that have been laid down along the present drainage courses and that are not considered to be of Pleistocene age. By far the most of the unconsolidated sediments of this region are assigned to the Pleistocene-that is, they are thought to have been laid down during the epoch immediately preceding the present one, when the drainage conditions were somewhat different, as outlined in the preceding section. As there stated (pp. 58-59), most of the Pleistocene sediments occur in terraces and sloping benches that stand from 50 to 1,000 feet above the flood plains of to-day. In general the present drainage system is cut down into the Pleistocene deposits, especially along the larger trunk streams, many of which flow at the bases of bluffs of unconsolidated sediments 100 feet and more in height. Most of the Recent alluvium is derived from these older unconsolidated sediments. The primary difference between the Pleistocene and the Recent deposits is that of position rather than of kind, and even in this regard the two are in places so intimately related by intergradation that it is difficult to separate them with satisfaction. For the most part the Recent sediments do not stand much above the flood plains of the present streams. As a rule benches of Recent silts or gravels are not more than 20 to 30 feet above the ordinary level of the streams which have laid them down.

In the larger valleys, however, where the flood plains are wider and where basins have been silted up recently, the latest deposits 
show other differences than those of position alone. They vary in composition, the Recent sediment being for the most part of a darker color than the older unconsolidated sediments with which they are .losely associated at many localities, and the darker color appearing to be due to the larger proportion of vegetable matter mixed with them. The vegetable matter in the Recent silts is apparently derived in large part from the peat deposits which lie mostly on top of the silts, but which are also at many places interbedded with them. In fact, it appears that the peat derived from the heavy growth of sphagnum mosses over all the swampy lowlands may be considered the most characteristic and widespread of Recent deposits. Peat beds several feet in thickness, interbedded with the silts, are exposed repeatedly along the low-cut banks of many of the larger streams. There are also some lenticular beds of ice exposed along the cut banks, and considerable of this "flood-plain ice" is deposited throughout the Recent alluvial lowlands. Where the rivers flow through lowlands the banks exhibit in many places alternating vegetable and silt layers, the former generally the more prominent. Associated with both there are scattered bowlders and embedded gravels, which are regarded as ice-borne. The surfaces of the flood-plain lowlands bear numerous ponds and lakelets, many of the latter being of the oxbow or abandoned-channel kind.

Immediately along the larger streams the bars of gravel and sand are the most characteristic deposits. These are naturally best developed on the inner sides of the wide curving bends of the larger rivers. Along the accordant drainage courses south of the Endicott Mountains such deposits are practically continuous, for at times of flood, especially in the spring, the rivers spread over valley floors, some of which are a mile or more in width, and deposit upon them a considerable sheet of gravel and detritus, a large part of which is exposed when the streams fall to their more normal stages.

Within the Endicott Mountains, where much of the lateral drainage is discordant with the trunk streams, the recently laid stream deposits are more or less disconnected and do not have well-adjusted gradients. Recent stream gravels at some places stand, as benches, at higher elevations above the streams that have deposited them than is usual south of the mountains. Alluvial fans are commonly developed at the mouths of tributary streams where they empty into the wide valleys of the larger rivers. In general the Recent stream deposits within the mountains are composed mostly of gravels and coarser detritus, and banks of silts and vegetable matter are not so common. The gold-bearing gravels and silts associated with them will be described in more detail in connection with the particular localities where prospecting and mining has been done. (See pp. 84-108.) 


\section{MINING.}

\section{PRODUCTION.}

Since placer gold was found in 1899 on Myrtle Creek, a tributary of Slate Creek, successive discoveries have been made on other tributaries of the Koyukuk, with the general result that the yearly production has steadily increased during the last 10 years, the newer finds more than compensating for the decreasing yield of the older placers.

The production of placer gold in the Koyukuk, though not so large in amount as that in the Nome and Fairbanks districts, has been noteworthy when its difficulty of access and small population are considered and has probably averaged higher per capita than that of any other district in Alaska. Since the discovery of the district its development has been practically accomplished with only its inherent mineral resources to aid mining enterprise, there having been, with one exception, no exploitation by capital from without the district. In other words, the Koyukuk stands as an entirely self-supporting mining community.

Schrader ${ }^{1}$ has published a table of production of gold for the Koyukuk district for the period from 1900 to 1903, based on the most reliable information he could obtain. The writer has endeavored to extend this table to the close of 1909 (p. 69). Schrader's table gives a total of $\$ 667,500$. To this he added $\$ 40,000$ as the approximate output of sundry smaller diggings not given in the list for $1901 ; \$ 6,000$ as the output in 1899, derived mostly from Myrtle and Slate creeks and various places on South Fork; and $\$ 3,000$ to $\$ 4,000$ from Tramway Bar bench and river bars in previous years, all of which gave an aggregate yield for the district to that date of about $\$ 717,000$. The revised and enlarged table presented here gives an approximate total production of $\$ 2,200,600$ for the 10 years 1900 1909. Up to 1909 the output of the year 1903 appears to have been the largest. This is easily accounted for by the facts that the shallow diggings were then at their best and that the very easily mined gravels on Mascot Creek yielded about $\$ 100,000$ during that summer. After 1903 there were several years of gradual decline in production, which appears to have reached its lowest point in 1906. The low yield for 1906 is partly explained by the rush to the new Chandalar placer district, about 75 miles east of Coldfoot, in August of that year, which took a number of men from productive work in the Koyukuk a month before the summer mining. season had closed. From 1906 to 1909 there was an increase of production each year which was derived largely from the deep placers on Nolan Creek.

1 Schrader, F. C., A reconnaissance In northern Alaska : Prof. Paper D. S. Geol. Survey No. 20,1904, p. 102. 
There is some uncertainty in assigning the figures of production since 1906 to separate calendar years, because the underground mining operations extend from one year into the next and the figures given for a particular claim cover parts of two years. In the table the production of Nolan Creek for 1908 and 1909, which has been the largest factor during these two years, has been arbitrarily divided; but it is thought that if the statements obtained as to the yield are reliable the totals are good approximate estimates, and that the table as a whole is as fair a summary as it is possible to present from the information at hand.

The gold production of the Koyukuk district declined during 1910 and 1911, amounting to approximately $\$ 160,000$ for 1910 and $\$ 140,000$ for 1911. During 1912 there was an increase over the two previous years, about $\$ 200,000$ being the estimated yield. As detailed information is not at hand for apportioning the output for these three years to the various creeks, no attempt has been made to extend the table. However, probably 75 per cent of the gold output for these three years has been produced from the deep mines on Nolan Creek and new workings of deep gold-bearing gravels in the lower valley of Hammond Creek that have been developed during 1911-12. It is thought that the increase -for 1912 may be chiefly credited to Hammond Creek.

As thus estimated the total placer-gold production of the Koyukuk district up to 1912 , inclusive, is about $\$ 2,700,000$.

Estimated production of placer gold in the Koyulcuk district from 1900 to 1909, by localities and years.

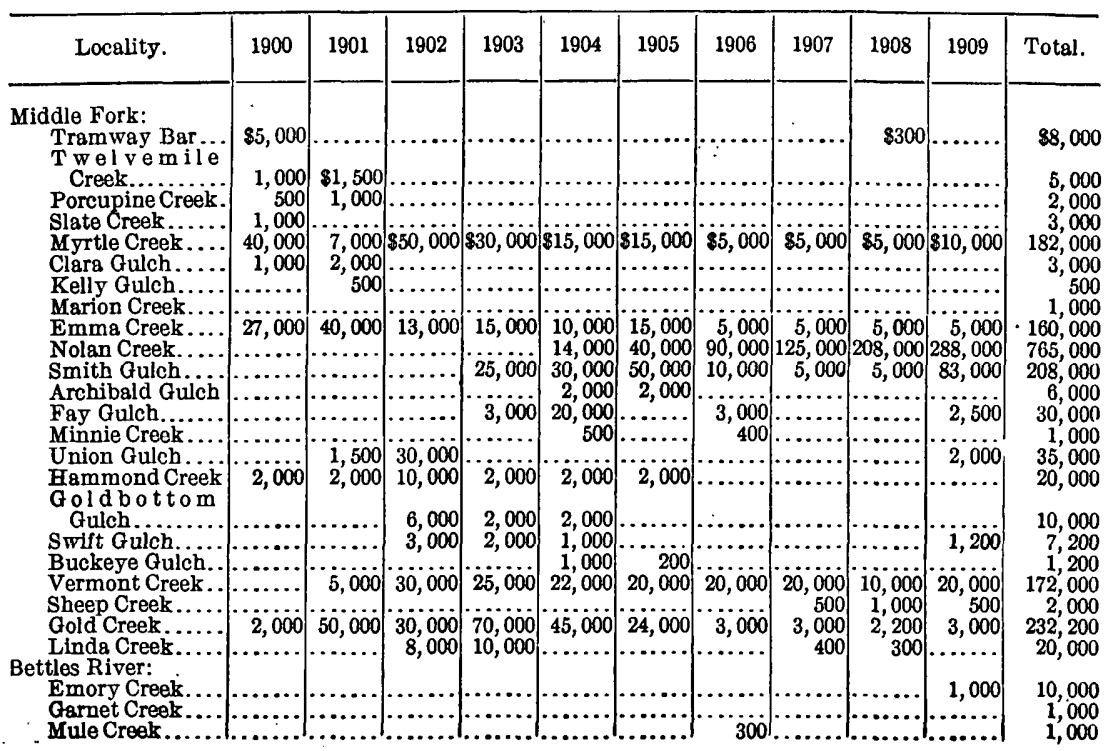


Estimated production of placer gold in the Koyukuk district, etc.-Continued.

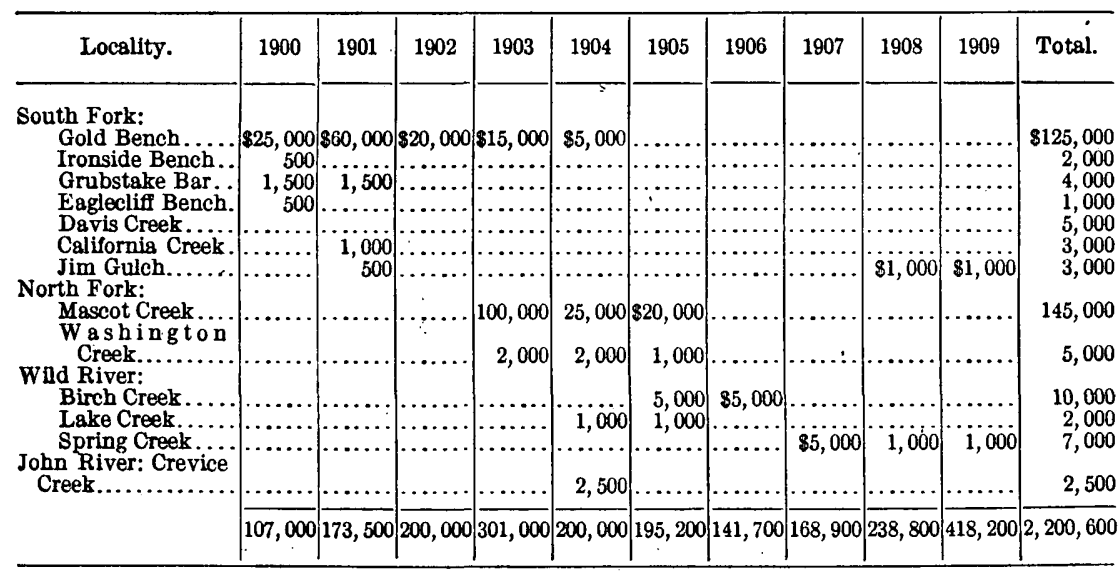

The results of mining as summarized above have been accomplished by an average of 100 men a year who have actually worked at mining. Some men have left the district each year, but others have come to replace them. If the average cost of production is placed at about 50 per cent of the total yield, about $\$ 1,350,000$ may be considered the amount of wealth that has been taken away from the Koyukuk district during its mining development by those who ' have become satisfied with their gains and have departed from Alaska for "the outside with a homestake," as it is called in. that country.

The Koyukuk placer gold is of a high grade. Its refined value varies from $\$ 18$ to over $\$ 19$ an ounce. The unrefined gold has passed in commercial exchange at $\$ 17$ an ounce until 1909 , when it was allowed a value of $\$ 18$ an ounce.

The subjoined table gives an estimate of the production of both gold and silver from 1900 to 1911 :

Estimated production of placer gold and silver in the Koyukuk district from 1900 to 1911.

\begin{tabular}{|c|c|c|c|c|}
\hline \multirow{2}{*}{ Year. } & \multicolumn{2}{|c|}{ Gold. } & \multicolumn{2}{|c|}{ Silver. } \\
\hline & $\begin{array}{c}\text { Fine } \\
\text { ounces. }\end{array}$ & Value. & $\begin{array}{c}\text { Fine } \\
\text { ounces. }\end{array}$ & Value. \\
\hline \multirow[t]{2}{*}{ 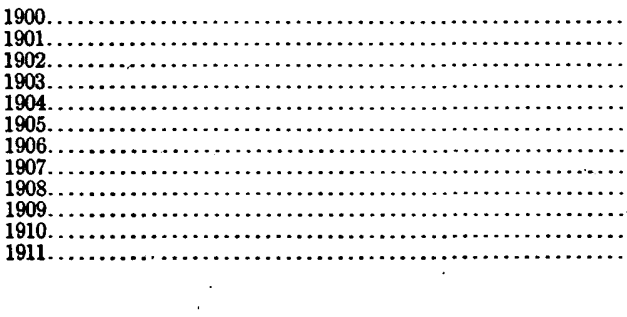 } & $\begin{array}{r}5,176.13 \\
8,393.06 \\
9,675.00 \\
14,560.87 \\
9,675.00 \\
9,442.80 \\
6,854.74 \\
8,170.53 \\
11,551.95 \\
20,230.42 \\
7,740.00 \\
6,772.50\end{array}$ & $\begin{array}{r}\$ 107,000 \\
173,500 \\
200,000 \\
301,000 \\
200,000 \\
195,200 \\
141,700 \\
168,900 \\
238,800 \\
418,200 \\
160,000 \\
140,000\end{array}$ & $\begin{array}{r}310 \\
503 \\
581 \\
874 \\
580 \\
567 \\
411 \\
490 \\
693 \\
1,214 \\
464 \\
406\end{array}$ & $\begin{array}{r}\$ 192 \\
302 \\
308 \\
480 \\
286 \\
346 \\
280 \\
323 \\
367 \\
631 \\
250 \\
215\end{array}$ \\
\hline & $118,243.00$ & $2,444,300$ & 7,093 & 3,980 \\
\hline
\end{tabular}




\section{METHODS OF MINING.}

SURFACE MINING.

Shallow placer mining can be most economically conducted by excavating some kind of opening into the natural surface of the deposit and removing all the material associated with the gold down to the real or "false" bedrock, upon which most of the gold generally rests. The methods of moving the unconsolidated material are many-hand shoveling, ground sluicing, hydraulicking, horse or steam scraping, steam shoveling, derricking, and dredging, singly or in various combinations. Where the more efficient mechanical means, such as steam shoveling or dredging, are employed for moving the gravels from open surface excavations, placer deposits 40 feet or less in depth may be termed shallow and, if frozen, may be thawed artificially to this depth to facilitate the operation of heavy excavating machinery. If the deposits are treated by ground sluicing or hydraulicking with plenty of water, the thawing of frozen ground may sometimes be accomplished to this depth as the excavating progresses. But as soon as the depth increases beyond a point where the deposits can not be worked profitably by surface excavating methods they merge into the class of deep placers. Whether any particular deposits may be properly called shallow or deep placers depends upon the method of working employed, for the two classes may overlap.

In the Koyukuk only the methods of hand shoveling, ground sluicing, and hydraulicking have been used up to the present time. Hand shoveling, sometimes in combination with a little ground sluicing, in the shallow unfrozen stream and bench gravels less than 6 feet deep, has been the method by which most of the gold has been mined in this district. Six feet may be considered about the limit of depth of shallow unfrozen ground that may be mined profitably by hand shoveling, and deposits of this kind are naturally the best suited for immediate development by men whose principal capital is hardihood and a willingness to work. Consequently these shallow placer deposits are the kind most sought for, because they yield the largest returns for the least apparent investment of time and capital. There appears to be little doubt, however, that the crude manual methods it has been necessary to employ in this district up to the present time are expensive and have failed to save all the gold originally in the gravels, and that there are considerable deposits of shallow goldbearing gravels that can never be worked successfully by pick and shovel but may be mined with hydraulic equipment. So far the only hydraulic plant is the one on Myrtle Creek (pp. 88-89).

UNDFRGROUND MINING.

Deep mining is the kind that is carried on beneath the ground without changing the surface configuration. This method is adapted 
for mining deposits in which the valuable strata are so deeply buried under barren material that they can not be mined successfully by any kind of open surface works. Deep gold-bearing deposits are the most distinct class of placers, because they can be practically worked by only one method of mining. This method consists in sinking shafts down to the gold-bearing strata and mining these beds out by lateral drifts, or, if the deposit is a favorably situated thick bench, by carrying drifts alone into the deposit along the goldbearing beds. As these deposits are generally solidly frozen in northern Alaska, the usual practice is to thaw them by the use of steam. Such operations have been extended to depths of 200 to 300 feet. Owing to the generally frozen condition of the thick unconsolidated deposits the method of mining the deeply covered placers they contain is practically the same throughout Alaska. The necessary machinery for this class of placer mining, with various local improvements suggested by experience, has been well perfected in the Fairbanks and Nome districts during the last 10 years, and these towns are the centers of supply for such machinery for Alaska. The equipment consists of a suitable-sized steam boiler and hoist, small and light for prospecting and larger for regular mining, together with steam pipes, pieces of steam hose, fittings, and a supply of strong hollow bars about 6 feet long provided with steel points at one end and a pounding head at the other for driving into the frozen ground to introduce the steam.

The Koyukuk district, being difficult of access, is not well provided with this kind of equipment. The supply there at present is not only inadequate but poor and expensive. Most of the boilers are patched-up makeshifts. Pipe, hose, and fittings are scarce, and the prices asked for them are unreasonable. Because of this unsatisfactory commercial condition, the method of prospecting with steam boilers and hoists has not been used systematically on the deep gravel deposits. Productive mining of this kind has been carried on, but these operations are confined principally to about half a dozen claims on Nolan Creek, one claim on lower Vermont Creek (pp. 93, 96, 98), and the valley of Hammond River, of which Vermont Creek is a tributary.

\section{COSTS AND WAGES.}

It is impossible to give a detailed analysis of the commercial mining status of the Koyukuk district, because direct evidence in the form of actual figures from books is not available, but from general information the principal features may be outlined.

All the goods consumed by the residents of this district, with the exception of a very small amount of game and fish procured locally, are brought from the States, and the freight charges alone for delivery at the mining localities are from 10 to 20 cents a pound. 
Prices in 1909 were considerably below the average for the previous 10 years as a result of recent competition in the commercial enterprise of the district. Likewise the present scale of wages is considerably less than it has been during the past, and no doubt if accurate figures could be obtained they would show that the high retail prices of provisions have directly controlled the scale of wages. The amount of supplies available has had considerable influence on prices. On a number of occasions a shortage of some articles has occurred in spite of the high prices asked, and 1909 was the first year in the history of the district in which a satisfactory amount of provisions was in stock at the mining settlements when summer transportation on Koyukuk River closed.

Very few miners in this district keep good records of costs of operation, and it is difficult to obtain accurate statements of the yield of gold, so both have to be approximately estimated in order to make comparisons.

The annual cost of proper food and clothing for the average prospector or miner in 1909 was about $\$ 1,000$. Ordinary manual labor at present is paid from $\$ 4$ to $\$ 6$ a day, with food. The cost of food per man varies from $\$ 3$ to $\$ 5$ a day, according to the cost of transporting provisions from the settlements to the places where mining is being done. Before underground mining was developed on Nolan Creek, in 1906, there was little demand for day labor, and when men were employed for a period of time the usual wage was $\$ 1$ an hour, without board; but a large part of the mining, especially the shallow shoveling kind and considerable of the deep mining, is done by groups of men who enter into partnerships and work on shares.

Under present commercial conditions only the richest placers of this district yield returns that are considered an adequate reward. A few of the most profitable operations are stated to have been conducted with a profit of 70 per cent of the gross yield of gold, or at a cost of 30 per cent of the production. These results, however, have been obtained only in a few localities of the richest deep ground on Nolan Creek and in the most easily worked shallow unfrozen ground, notably on Mascot Creek. Most of such opportunities have been short lived, and a large part of the mining has been done with a relatively low percentage of profit, so low in many instances as to furnish no more than a bare living under the harsh conditions of climate and isolation that characterize this region, where only the optimism that is the predominant characteristic of the gold-seeker's temperament serves to stimulate many of these men to continued effort from year to year. 


\section{ECONOMIC GEOLOGY.}

\section{GENERAL CONDITIONS.}

In the Koyukuk district the only mineral of present commercial value is placer gold. So far as known to the writer no lodes carrying gold in commercial amounts have been found in the district and little bedrock prospecting for such deposits has been done.

Little evidence of the presence of promising veins of quartz is to be seen on the moss and turf covered mountain slopes, and where vein quartz is exposed or indicated by talus fragments along the higher bare ridges or in the stream cuts it is for the most part of the barren unmineralized kind commonly called "bull quartz." Veinlets of quartz containing free gold and pyrite have been found occasionally, but these are usually less than an inch thick and only a few feet long and, so far as known, are so irregular and scattered as to be of no value for lode mining. Nevertheless the probability of the occurrence of workable gold-lode deposits in the Koyukuk district can not be said to be wholly unfavorable. In the absence of actual lode discoveries the only suggestion that can be offered as to the most likely areas is to call attention to the distribution of gold gravels along certain streams where all the evidence points toward the probable derivation of the placer gold from the bedrock of the areas in which such streams have eroded their drainage basins. On the assumption that the gold has its bedrock source in some mineralized form within such areas it is desirable to examine them thoroughly enough to determine the presence or absence of mineralized veins or stockwork zones of workable dimensions.

A good illustration of such an area is afforded by a mountain mass about 4 miles square bounded by Middle Fork of Koyukuk River on the east, Hammond Creek on the north, Vermont and Nolan creeks on the west, and Wiseman Creek on the south, within which the gravels of nearly all the gulches contain more or less placer gold. It appears to the writer that the placer gold of Nolan Valley, which flanks the southern half of the western slopes of this area, has been largely if not entirely derived from gravels that have been washed into the valley from the tributary gulches along the east side. The most important of these gulches, named from south to north, are Smith, Archibald, Fay, and Webster; these, together with several unnamed gulches, have their basins eroded from the southwest portion of the mountain area defined above. Likewise the gold-bearing east branch of Vermont Creek is eroded from the northwest part of this mountain mass. On its north flank, between Vermont Creek and the Middle Fork, where this same mountain area forms the steep southern side of the lower valley of Hammond Creek, it is dissected by several gulches, the larger of which are named, from west to east, 
Buckeye, Swift, and Goldbottom. The gravels of these gulches contain more or less placer gold, which is undoubtedly derived from the bedrock of the mountain mass to the south out of which they have been eroded. Like the gulches tributary to Nolan Valley already mentioned, these gulches appear to be the feeders that have supplied most of the gold now found in the deep gravels of Hammond Valley. The east side of this area is dissected by Confederate, Union, and several smaller gulches which discharge into the Middle Fork. Both Confederate and Union gulches contain workable gold-bearing gravels.

To summarize, it may be stated that the gravels of practically all the larger gulches that are eroded into the bedrock of the mountain mass under consideration contain placer gold. It is not uncommon to find pieces of unworn angular quartz in the gravels of these gulches with rough vein gold attached to or embedded in them. A few veinlets of quartz containing free gold and pyrite are known to occur in place and a phyllite schist member of the bedrock of this area is mineralized with gold-bearing pyrite. There is no doubt that gold occurs in the bedrock of this mountain area, and there can be little doubt that the source of a large part of the placer gold of all these gulches is in the bedrock of the mountain mass from which they have eroded their basins. These placers are rich enough to warrant the assumption that the mineralization of bedrock is considerable.' Therefore it seems that this mountain area is a favorable one to prospect, with the object of discovering the gold in definite lodes or zones, although it may be learned that the gold is so dispersed throughout the bedrock as not to form workable lodes, especially in a region like this where the mining costs are high.

In the Chandalar district, on the other hand, probably the most promise lies in its known quartz-lode gold deposits, for the placers so far found there appear to be rather local alluvial concentrations of gold derived from quartz veins near by. A number of these veins have been located and prospected since 1907 , but no producing mines have yet been established because of the difficulty in transporting the necessary mill machinery and supplies to the camp. Several of the quartz bodies that have been opened have yielded remarkably good assays. Within 75 feet of the surface much of the gold is free, and in the one or two places where prospecting has been extended to a depth of about 100 feet the free gold content of the sulphide ores is still marked. A more detailed account of this district is given on pages 110-116.

Indications of other minerals besides gold are occasionally found. For instance, pieces of galena are in places associated with the placer gold, and this mineral is reported to occur at several localities in the limestone belt that lies northwest of the gold-bearing schists. 
One of these localities is in the upper valley of Wild River and another is on Bettles River. Native copper and silver are reported to have been found in small amounts on a northern tributary of Bettles River in association with placer gold.

On the Middle Fork just above Tramway Bar, in the southern part of the Koyukuk district, there is at least one coal bed of workable thickness. It is about 12 feet thick. The middle 9 or 10 feet is good fuel of a low-grade bituminous quality, but no development of it has been undertaken up to the present time, though it should prove to be serviceable for local use.

\section{HISTORICAL OUTLINE.}

Placer gold was first found in this region in the river bars of the Koyukuk some time between 1885 and 1890, when it was visited by a few of the first prospectors who came to the lower Yukon Valley. John Bremner, who was killed by an Indian on Hogatza River in 1888 , was one of these pioneers.

Previous to 1898 the placers at Tramway Bar bench, and two other localities several hundred miles down the river, named Hughes and Florence bars, appear to have been the best-known occurrences of placer gold in the Koyukuk Valley, and it is estimated that about $\$ 4,000$ worth of gold was mined from them. It is interesting to note that Florence Bar is only a few miles below the newly developed Red Mountain placer gold district, situated on the central Koyukuk about 380 miles up the river from the Yukon. Here, in 1910, gold-bearing gravels were found in the basin of Indian Creek, a tributary from the east about 4 miles above Waite Island. A new settlement named Hughes has been established on the east bank of the Koyukuk a short distance above Indian Creek, but it has not been learned whether or not the situation of this settlement has any reference to the former Hughes Bar diggings. The gold of Florence Bar may have been derived from some of the gold-bearing tributaries in this vicinity, such as Indian Creek.

Since 1898 prospectors have searched for gold within the valleys of all the headwater branches of Koyukuk River, with the result that placer gold has been found in greater or less amounts in the gravels of some of the tributaries of John and Wild rivers and the North, Middle, and South forks of the Koyukuk, and also about the source of Big Creek in the Chandalar Valley. Search has also been made for gold in the valleys of Dall and Hodzana rivers, and it is reported that prospects have been found on some of the tributaries of these streams, but so far there has been no production from this part of the region. 


\section{DISTRIBUTION AND GEOLOGIC ASSOCIATION OF GOLD.}

The search for gold, which has been carried on more or less actively throughout the Koyukuk-Chandalar region since 1899, has been best rewarded on the tributaries of the Middle Fork. Placer gold is now known to occur in many of the creeks and gulches tributary to this river, from Chapman Creek and Tramway Bar on the south to the head of Bettles River, this being roughly the section of the Middle Fork drainage basin which lies within and crosses the northernmost belt of Birch Creek schist in this region, described on pages 35, 38-49. (See Pl. V, in pocket. In fact, with two exceptions, the streams furnishing by far the largest amount of placer gold from the Koyukuk-Chandalar region lie within the drainage area of the Middle Fork of the Koyukuk. The notable exceptions are Mascot Creek, a headwater tributary of North Fork, and South Fork at Gold Bench.

It is only from five to six of these streams that gold may be mined profitably under present conditions, and in many places work has been carried on from year to year with considerable uncertainty as to the result. This uncertainty is due in part to the nature of the gravel deposits but largely to the high cost of all supplies and to the primitive methods of mining, which in turn may be attributed to the general remoteness of the region.

The general features of relief are similar in every way throughout both the Koyukuk and Chandalar districts, and the development of the drainage system that has formed the dominant features of the region and the widespread deposits that have been laid down by the streams of this system are so intimately associated with some of the gold placers that it seems more logical not to separate the descriptions of their relations. The principal characteristics of this association have already been outlined (pp. 58-67). More detailed descriptions of the placer gold-bearing gravels and their geologic association with the widespread gravel deposits of the region will be given for particular localities (pp. 84-110).

It is obvious that the gold-bearing gravels which are buried beneath silts, such as those which partly fill the valleys of Nolan Creek and Hammond River to depths of 50 to 100 feet and more, must have been laid down before the silts were deposited and are therefore older than the silts. If the silts were deposited in these valleys. during glacial time the bedrock troughs of the valleys and the gold-bearing gravels along their bottoms must be older than the stage of glaciation during which the silts accumulated. As the period of glaciation of the Endicott Mountains is considered to be contemporaneous, in a general way, with that of the rest of North America-that is, of Pleistocene age-it seems that some of the placer gold-bearing gravels of this region are at least as old as early Pleistocene. 
It is possible that before the glaciers were formed some of the valleys of this region contained gold-bearing gravel deposits which were not favorably situated to escape the erosion of the ice and which consequently were removed and had their gold contents scattered throughout parts of the widespread outwash gravels already described. (See pp. 58-66.) This may account for the particles of gold said to be found by prospectors in the terrace gravels at many places. It is probably correct to say that the geologic age of the placer gold ranges from early Pleistocene to the present.

\section{CLASSES OF PLACERS.}

\section{CRITERIA FOR' CLASSIFICATION.}

The methods of working gold-bearing deposits of gravel depend upon their kind and condition. As the kinds and conditions are merely the result of various intergradations of common geologic processes-the wasting away of the hard country rocks by erosion and the transporting, wearing, sorting, and depositing of the loosened materials by water, both in its fluid and frozen state-no sharp distinction can be drawn between the various classes of placer deposits. At the same time they present some differences that may be used to separate them into more or less distinct groups and classes.

The placers in the Koyukuk district may be classed according to the position, thickness, and composition of the various members of the unconsolidated formation in some particular layers of which the gold usually has been more or less concentrated in commercial quantities by the moving water that has washed down or built up the deposits to their present form. These placers may be divided into two groups, one of which occupies the bottoms and the other the side slopes of the present valleys. Each of these groups may in turn be subdivided into two classes, one in which the percentage of barren covering material associated with the gold is small, and another in which it is large.

\section{PRESENT STREAM PLACERS.}

The group of deposits that occupy the immediate bottoms of the valleys and that usually lie along the channels of the present streams consists of two classes. The first class comprises shallow gulch, creek, or river placers in which gold is usually found on or near bedrock in a bed of gravel from a few inches to 4 or 5 feet thick. These deposits are generally in unfrozen condition during the summer while the streams are flowing. To mine them it is necessary to move mechanically practically all the overlying unconsolidated mate- 
rial and in places also the upper part of the decomposed country rock. The second class comprises gulch, creek, or river placers in which the gold-bearing gravels, as in the first class, lie usually on or near bedrock along the bottoms of the present valleys, but in which they have been deeply buried, in places to a depth of several hundred feet, by gravels, sands, and clays, and locally by a mixture of vegetable matter commonly called muck. The whole overburden is generally quite barren of gold, and on top of it flow the present streams. These deep deposits are generally solidly frozen throughout the year except during the summer in places where streams flow over their surfaces, and except in some of their more porous beds of gravel where underground water is plentiful enough to circulate rapidly. To mine these' buried deposits successfully it is necessary to remove the part which contains gold in commercial quantities with the least expense. This is usually accomplished by moving as small a percentage of barren material as possible.

Of the two classes the shallow, periodically unfrozen placers may be considered the younger and more primitive, because this is the position and condition the pieces of gold assume when they are first detached from their bedrock sources by the agencies of disintegration and delivered to the agencies of transportation (chiefly moving water), to be carried and concentrated in the form of placers.

\section{BENCH PLACERS.}

The second group of placers comprises the deposits that do not occupy the present stream channels or bottoms of the valleys but. are in positions on either or both sides of the valleys, usually at higher levels, where they were deposited when the streams formerly flowed from a few to several hundred feet above and to one or the other side of their present positions. These deposits are generally called bench placers, and they may be subdivided according to position alone into high and low deposits, to express merely their height relative to the present drainage levels. Those that contain gold, however, may be best subdivided into two classes, like those of the first group-that is, according to the position of the gold-bearing layers in the deposit and the relation of these layers to the thickness, composition, and condition of the various materials. One class includes shallow bench placers where a stream does not now flow over the gravels and where the gold is associated with gravels a few feet or less thick, resting either on bedrock or on a layer of more or less compact unconsolidated material that answers the same purpose and is called "false bedrock." Shallow bench placers are mined in a manner similar to shallow gulch or creek placers, by moving practically all the material in the gold-bearing area from the surface 
down to the real or "false" bedrock. The other class of this group comprises deep bench placers where the gold-bearing gravels are the same as those of the shallow class but are covered by an overburden of considerable thickness that generally does not contain gold in commercial quantities. These placers can be best mined by methods that do not disturb the surface configuration of the deposit-that is, by means of shafts and drifts or by drifts alone.

\section{UNCONSOLIDATED FORMATIONS.}

The condition of the water, whether frozen or liquid, contained in the unconsolidated deposits of this region is important, for it directly governs the method of working best adapted to get any valuable minerals they may contain. Over all northern Alaska the unconsolidated deposits, whether gold-bearing or not, are as a rule firmly bound together by widespread and almost constant frost or ice throughout their thickness and extent. This condition also extends to some depth into the hard country rocks wherever percolating water penetrates them. The amount of unfrozen ground in northern Alaska is a very small percentage of the whole, and even this is usually in an unfrozen condition only for about one-third of the year, during the season of flowing surface water or the few months of summer. Occasionally the larger streams carry enough circulating water through the more porous beds of gravels in their valleys to maintain an unfrozen condition throughout the whole year.

The placers of the Koyukuk district may be classified according to the three elements of position, thickness, and composition, but the fourth element, that of condition, applies so uniformly to nearly all the unconsolidated deposits for the whole or larger part of each year that it is not so distinctive as the other three elements. It is, however, of much more economic importance, because the progress of placer-mining development is largely governed by the frozen or unfrozen condition of the unconsolidated formation.

\section{SUMMARY OF CLASSIFICATION.}

The following statement is an attempt to express the above classification more concisely:

\section{Classes of placers in the Koyukuk:district.}

Group I. Present stream placers. Deposits occupying a position in or under the present flood plains :

Class 1. Uncorered. Shallow gulch, creek, and river placers in which gold is found on or near bedrock associated with gravels from a few inches to 5 or 6 feet thick along the immediate beds of present streams. Largely unfrozen during the summer season of flowing water. Easiest and cheapest to mine. 
Class 2. Covered. The same kind of placer as class 1 above, in the same position near bedrock, but buried to depths in places as great as several hundred feet by alluvial deposits that generally do not contain paying quantities of gold. Largely frozen solidly throughout the year except on the surface during summer. More difficult and expensive to mine.

Group II. Old stream placers; bench placers. Deposits occupying positions on either or both sides of and usually at higher levels than the present flood plains.

Class 1. Uncovered. Shallow gulch, creek, and river placers of former drainage channels, where the gold is associated with a few feet of gravel on top of either bedrock or unconsolidated deposits. Often unfrozen. Easiest and cheapest to mine.

Class 2. Covered. The same kind of placer as class 1 above, where the gold-bearing layers may rest on bedrock or a compact layer and are covered to a considerable depth by later deposits that generally do not contain paying quantities of gold. Generally solidly frozen throughout the year. More difficult and expensive to mine.

The foregoing classification of the Koyukuk placers applies equally well to all the stream placers of Alaska, except that frozen ground is not so deep nor so general on the Pacific slope portion, where the climate is not so severe.

A group for residual placers, which in natural sequence should precede group I of stream placers, and a group for beach placers, which should follow group II of stream placers, in all making four groups of placer deposits, would complete the above classification. Residual and beach placers have not, been considered here, because in the Koyukuk district they are very scarce.

In the Koyukuk district gold-bearing bench deposits are common and probably more extensive in area than the creek and gulch placers. The benches occupy positions from low banks along the present streams up to heights of several hundred feet on the side slopes of the valleys. So far they have not been mined as extensively as the creek and gulch deposits, because most of them are not in favorable positions with regard to water supply for profitable mining with a small amount of invested capital. They will best be treated by hydraulic methods, and this form of mining has not been developed to any extent in this district.

Thus the Koyukuk placers range from shallow deposits that are unfrozen during the summer to those that are deep and permanently frozen. The arrangement here adopted expresses in a general way the natural progressive sequence of formation from the younger to older kinds, and from the easiest and cheapest to the more difficult and expensive to mine. Though there are all gradations between the most shallow unfrozen to the deepest solidly frozen kinds, with regard to methods of working they may be conveniently separated into two kinds-shallow and deep or surface and underground.

$76032^{\circ}-$ Bull. $532-13-6$ 


\section{SOURCE OF PLACER GOLD.}

It has already been noted that the Birch Creek schist of the Koyukuk district contains a carbonaceous schist or phyllite that has been well silicified. The quartz is rather finely and uniformly disseminated throughout much of the rock, but in some places it occurs largely in the form of gashed and laced stringers of secondary quartz and in more or less lenticular or knotty bodies that have a general tendency to swell and wedge out and follow the curves and crenulations of the schistose structure. In other localities more intense metamorphism appears to have altered the carbonaceous rock with its quartz content into a micaceous quartz schist. That is, this rock apparently varies horizontally from a carbonaceous phyllite, locally having slaty cleavage, to a carbonaceous schist with more or less secondary quartz, at some places finely disseminated, at others more or less segregated; and here and there it has been still further altered into a more typical schist of the micaceous quartz variety, some of which shows graphitic phases.

The form in which the secondary quartz occurs at different localities has undoubtedly been largely influenced by the relative physical rigidity of the various rock members. The more rigid quartzitic' phases and igneous rocks have been fractured or shattered into fragments and blocks, affording opportunity for quartz to be deposited in gashed and laced veinlets, while the members of finer-grained texture appear to have been kneaded like putty rather than broken, and as a consequence the quartz now contained in them is more finely and evenly disseminated and is not so conspicuously segregated as in the harder rocks.

The disseminated and segregated quartz content of these rocks may be an original constituent or it may have been introduced by migrating solutions from other rocks during the progress of metamorphic changes, or it may very probably have been derived from both these sources through a long period of metamorphic alteration. Where the rock is fine textured and is a more typical phyllite the quartz is more finely disseminated, and locally; at least, this phase also contains a considerable amount of gold-bearing pyrite distributed through the rock as well-formed, sharp individual crystals. The rock at such localities might be called a pyritized phyllite or schist. A selected sample of fresh sharp crystals of this pyrite from Nolan Creek assays $\$ 1.24$ in gold to the ton. Where the quartz content of the rock occurs more in the form of knotty segregations and veinlets the pyrite is present in both the country rock and the quartz, though most of the quartz appears to be quite barren; but some weathered pieces of this quartz show oxidized pyrite, cubical cavities from which pyrite has evidently been removed, and small flakes and particles of free gold. Assays of samples from the quartz segregations 
and veinlets that occur in the micaceous quartz schist phase of these rocks show that gold occurs sparingly in that phase also.

The evidence outlined above appears to be sufficient to warrant the conclusion that the placer gold of the Koyukuk district has its chief source in the carbonaceous phyllite and micaceous quartz schist phases of the Birch Creek schist, because the pyrite that formation contains is known to be gold bearing and the quartz veinlets and lenses characteristic of parts of it are known to contain free gold. No doubt the form and condition of the gold as it now occurs in the bedrock are the result of one or more cycles of complicated changes and segregations, and the coarser placer gold in the gravels represents gradual accumplations from the erosion of a great amount of this mineralized country rock. Whether the mineralization was confined to any particular rocks, and if so what its distribution within the rocks may be, can not now be definitely stated. Only detailed study will show the real relations and the manner in which they have come about.

In the Koyukuk district proper the evidence goes to show that the placer gold has, for the most part, been derived from stringers and veins in the schists and slates. The definite relation of these to the intrusive rocks is not so evident as it is in the Chandalar district, where the facts in hand go to indicate that the mineralization is genetically related to the intrusion of granites and granodiorites. In this field some fairly well defined quartz veins have been found and considerable prospecting has been done on some of them. These veins occur in association with intrusive rock, a fact which is in accord with the general law governing gold mineralization in other parts of Alaska. This law is, in effect, that the mineralization is closely connected with granitic or dioritic intrusives. Some evidence has been presented elsewhere (p. 33) indicating that the mineralization in the Koyukuk district may not have been confined to the schists but may also have occurred in the younger Mesozoic rocks. It need hardly be added that the evidence at hand is not sufficient to determine definitely that the district may not contain auriferous veins which are genetically related to the intrusive rocks.

\section{THE PLACERS.}

\section{KOYUKUK DISTRICT.}

DRAINAGE BASINS.

The Koyukuk district may be considered to embrace all the area drained by the North, Middle, and South forks of the Koyukuk, lying approximately between $67^{\circ}$ and $68^{\circ}$ north latitude and $149^{\circ}$ and $150^{\circ} 50^{\prime}$ west longitude and covering about 4,000 square miles. 
The name Middle Fork is here applied to that branch of the Koyukuk which is formed by the confluence of Dietrich and Bettles rivers and flows southward and westward about 75 miles to the point where it is joined by the North Fork, 37 miles below Coldfoot. (See map, PI: I, in pocket.) The valley of the North Fork is the drainage basin immediately west of and roughly parallel to that of the Middle Fork, and the valley of the South Fork occupies the area east and southeast of the Middle Fork that lies between it and the drainage of the Chandalar basin. These three drainage basins may be considered to constitute the Koyukuk placer gold district, which is noteworthy as one of the most northerly mining communities in the world. Of the three the valley of the Middle Fork is the largest and by far the most important in the region so far as placer mining is concerned. Its gold-bearing creek, gulch, and bench deposits will be described first and considered in upstream order from south to north.

\section{MIDDLE FORK OF KOYUKUK RIVER.}

TRAMWAY BAR AND CHAPMAN CREEK.

Tramway Bar is one of the earliest known localities for placer gold in the Koyukuk Valley. Together with two other localities, Hughes and Florence bars, it was known and visited by a few of the first prospectors who came to the lower Yukon Valley between 1885 and 1890, when gold was first discovered in the bars on the Koyukuk. It is situated on the west side of the Middle Fork about 20 miles below Coldfoot. At the locality where it has been worked it consists of a deposit of stream gravels, at least locally gold-bearing, resting on a bench cut in conglomerate and sandstone from 80 to 100 feet above the river. The river has cut a canyon into the conglomerate formation to this depth for 3 or 4 miles, and the coarse unconsolidated gravels, ranging in size from fine gravel to bowlders 1 foot in diameter on top of the canyon walls, appear to be the wash of an old stream which flowed over the bedrock before the downcutting of the canyon took place. This old stream deposit, derived largely from the schistose rocks that form the mountains to the north, extends for several miles westward as a covering of the benches of the Middle Fork valley and far to the eastward on benches in the Chandalar Valley. The present channel of the South Fork of the Koyukuk is intrenched across these deposits in a north-south direction from Hungarian Creek to Granite Creek, and they extend up Mosquito Fork and its northern branch to and over a wide, flat divide, thence down Crooked Creek to its mouth, where they coalesce and appear to be the same as the thick bench gravels that are widely distributed throughout the Chandalar Valley. All the streams above mentioned are more or less intrenched in this gravel deposit, and 
scattered over its surface are numerous shallow depressions that hold Jakes and ponds. These high wash gravels are not known to contain gold, even in small quantities, throughout their extent or even over any considerable areas. In fact, gold appears to occur in them only at certain localities, of which Tramway Bar, on the Middle Fork, and possibly Gold Bench, on the South Fork, are the best known. The gold at Tramway Bar very likely has been introduced locally from Chapman Creek, an east-side tributary of Middle Fork, at present emptying into it about one-fourth mile above, whose former channel may have flowed across the bench. It is probable that all the bench gold deposits in the Koyukuk district that prove to be of sufficient value to be mined originated in some stream near by. It is said that several trials at mining the Tramway Bar bench deposits were made previous to 1899 , and other attempts have been made since that time, the last during the summer of 1908, when four men dug a ditch from several small lakes situated at a higher level about 3 miles back from the river that conveyed ample water to the bench for sluicing. But it appears that none of the different short periods of operation have yielded very satisfactory returns to the workers.

During the winter of 1908-9 prospectors sunk 13 or 14 holes from 9 to 14 feet deep along Chapman Creek from a quarter of a mile to a mile above its mouth. These holes passed through a layer of sand and reddish gravel without gold to a bed of blue schist gravel resting on clay and prospecting from 2 to 3 cents to the pan. Some bench deposits from 20 to 30 feet above the creek about 2 miles above its mouth were also prospected and found to contain from 5 to 10 cents' worth of gold in a layer of blue schist gravel 1 to 3 feet thick, but the deposit was not considered to be favorably situated on :ccount of a lack of an adequate supply of water for sluicing.

Three holes from 12 to 22 feet deep were also sunk in the channel of the Middle Fork through washed gravels to hard conglomerate bedrock, and one of the men who did this work told the writer that these present river gravels showed gold to the amount of 75 cents to the square yard of bedrock surface, and that immediately on the bedrock from 2 to 3 cents to the pan was found. The object of this work was to test the gravels for dredging.

The placer gold at Tramway Bar does not appear to be derived from the conglomerate formation on which it lies.

\section{TWELVEMILE CREER.}

Twelvemile Creek is a west-side tributary to Middle Fork, 12 miles above Tramway Bar and 8 miles below Coldfoot by the river. Its gravels are said to contain a little gold, but it appears to have been worked only casually and without any large reward. 
ROSE CREEK.

Rose Creek is a small west-side tributary to Middle Fork about 5 miles below Coldfoot. Discovery claim is 2 miles above its mouth. Here a few surface colors may be found, but the gravels are said to be about 130 feet deep. Claim No. 4 above Discovery, about 3 miles above its mouth, was prospected during the winter of 1906-7 by sinking a hole 113 feet deep to bedrock. Most of the wash passed through consisted of slaty, flat, shingle-shaped gravel, with about 20 feet of blue clay over a thin layer of gravel which rested on bedrock and which contained many colors of gold.

PORCUPINE CREEK.

Porcupine Creek is a west-side tributary to Middle Fork about 3 miles below Coldfoot. Its gravels are said to contain a great many large bowlders. Four men are reported to have worked there in 1901 and to have produced gold enough to average $\$ 8$ a day to the man.

SLATE AND MYRTLE CREEKS.

Slate Creek is the largest eastern tributary of Middle Fork. The settlement of Coldfoot is situated on its south side at its mouth, approximately 1,450 feet above sea level. About 8 miles above its mouth its principal tributary, Myrtle Creek, enters from mountains on the north, and its main branch heads in the same mountains about 12 miles farther northeast. Its most easterly headwater branch comes from a wide gravel-filled pass about 20 miles east of Coldfoot. This pass is about 2,300 feet above sea level, or 850 feet above Coldfoot. Several depressions in this pass hold small lakes, some of the drainage of which flows westward into Slate Creek and the remainder eastward into a fork of Boulder Creek, a tributary to South Fork.

The thick deposits of washed gravels that occupy the pass between Slate and Boulder creeks extend westward down the broad valley of Slate Creek and join the similar high gravels along Middle Fork valley. The floor of Slate Creek valley averages about a mile in width from the lower slopes of the high mountains on the north to those of the lower mountains on the south. Most of this valley floor is covered by a deposit of washed gravels from 10 to 40 feet thick. The present stream has intrenched itself in these gravels in the upper third of the valley but has not reached bedrock, while along the lower two-thirds of the valley the main stream and the lower 2 miles of Myrtle Creek have cut through the gravels and into the underlying bedrock, so that rock bluffs from 10 to 20 feet high, overlain by gravels from 15 to 30 feet thick, are exposed along their banks. In several places these rock-walled cuts are narrow enough 


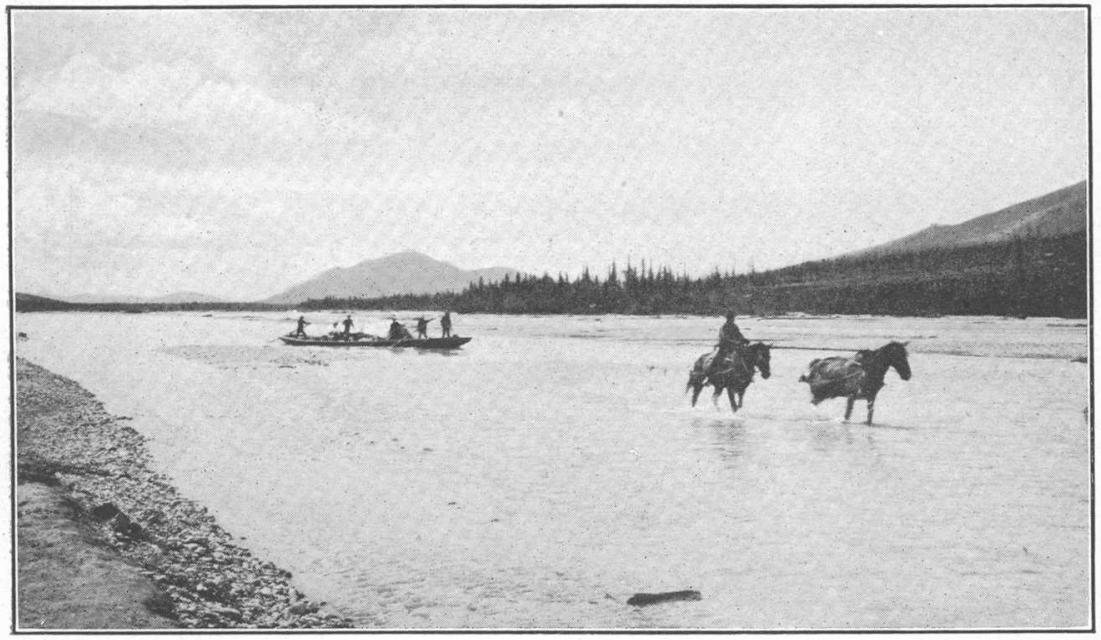

A. HORSES TOWING FREIGHT SCOW BETWEEN BETTLEES AND NOLAN, ON MIDDLE FORK OF KOYUKUK RIVER.

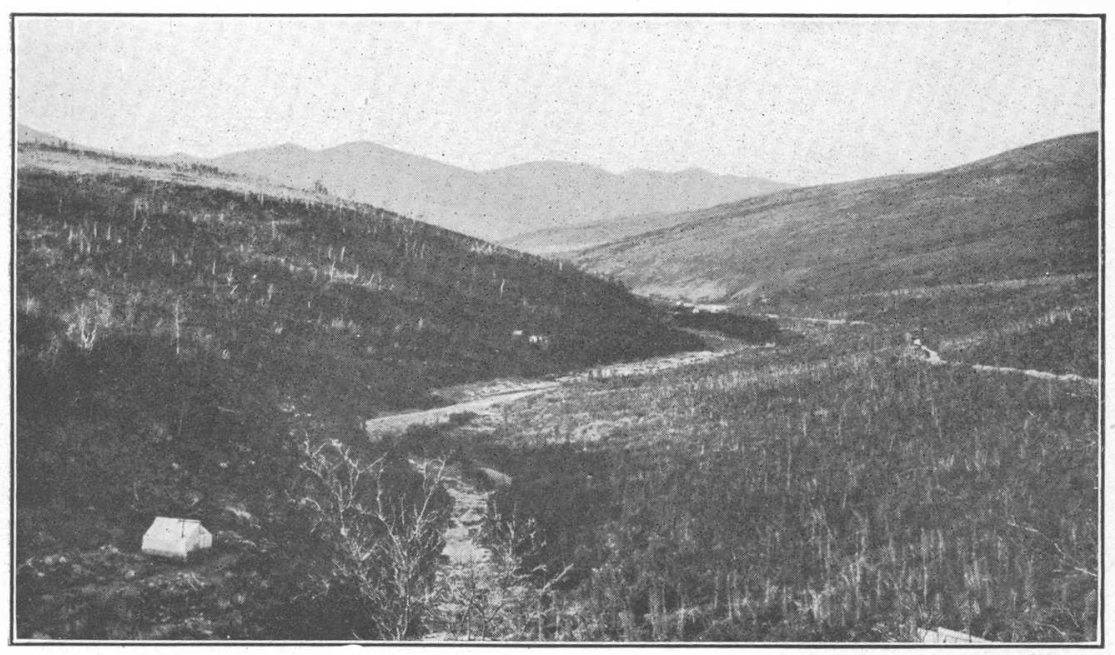

B. MYRTLE CREEK VALLEY.

Looking upstream from bench of ciaim No. 6. Hydraulic ditch along left slope. 
to be called canyons. On the surfaces of the gravel benches, along the valley, are depressions, some of which are occupied by lakes and ponds, that from their position and arrangement appear to represent parts of the courses of one or more old streams that flowed on top of the gravels during a former period.

The bedrock of Slate Creek valley consists principally of a carbonaceous phyllite that shows in places slaty cleavage and a micaceous quartz schist, both of which contain considerable segregated quartz in the form of veinlets, leaflets, and knotty lenses. There are also several dikes of altered dioritic intrusive rock, which has a spekled greenish-gray color and a medium grain. The gravels throughout the valley are the residual débris of these rocks. The dike rock is the hardest and forms the largest bowlders, a few of which are as much as 6 feet in diameter. Most of the gravels are derived from the schistose rocks, and because of this they show a strong tendency to form flat, slabby shingle, the coarser pieces of which average 6 inches in longest dimension. The whole deposit of gravel is very cleanly washed, very little sand, silt, or sediment being mixed with it. As a result water seeps through it readily and it does not pack closely but lies loosely in the bars, which are consequently not easy to walk over.

Placer gold was discovered on Myrtle Creek in March, 1899, by members of a party of gold seekers who came to Alaska during the excitement of 1898. Coarse gold is said to have been first found on claims Nos. 10 and 11, about $2 \frac{1}{2}$ miles above its mouth. There is no "Discovery claim" on Myrtle Creek, the claims being numbered from 1 at its mouth to 33 on its headivaters, a distance of more than 7 miles. The gravels along the present stream bed are from 2 to 4 feet in depth and from 100 to 300 feet in width. (See Pl. VIII, B.) There are also banks of gravel 6 to 10 feet thick along the sides of the stream in many places, especially on its upper course. In the lowe! $2 \frac{1}{2}$ miles Myrtle Creek has intrenched its channel through the gravel sheet that forms the benches throughout Slate Creek valley and to some extent it has also cut down into the bedrock underneath the bench gravels.

The present stream gravels along Myrtle Creek have been worked more or less from a point near the mouth of the creek up to claim No. 20 but have not proved profitable above claim No. 15 . The seven creek claims from No. 9 to No. 15 have been the most productive. Considered in a general way, the gold has been found well scattered across the width of the present bed of the stream and mining hus yielded an average of $\$ 5$ to $\$ 15$ a day to the man. All the work along the creek has been done with shovel, pick, and sluice box., the loose shingle gravels from 2 to 4 feet thick being favorable for this kind of mining. This work has been carried on more or less actively during each summer since 1899. Nearly all this shallow ground is 
now worked out. The largest yield of gold has been mined from claim No. 11; claims No. 12 and No. 9 have been the second and third best producers, respectively. These three claims are on that part of the creek from 2 to 3 miles above its present confluence with Slate Creek, just below the point where it leaves its mountain valley. Below these claims Myrtle Creek flows through the bench gravels of Slate Creek valley, and these together with the underlying bedrock compose its banks. Above claim No. 12 the bedrock slopes of the mountains that bound the real Myrtle Valley come down near the stream on both sides, and here and there it cuts rock bluffs at the bases of these slopes. Thus the richest deposit of gold appears to have been laid down just beyond the mountains, in that part of the creek that was its mouth when the main drainage along Slate Valley may have occupied a more northerly position or when Myrtle Creek was at a higher level and dumped its gold-bearing gravels out upon the gravels of Slate Valley, to be mixed with the bench deposits. The gold of this locality is probably all derived from the wearing down of the bedrock of the mountains from which the valley of Myrtle Creek has been eroded.

The bench gravels along the sides of the lower 2 or 3 miles of Myrtle Creek carry some gold and are now being mined by a small hydraulic plant situated on the east side bench of claim No. 6. These bench gravels consist largely of Slate Creek channel wash. As exposed by the cut of Myrtle Creek along its lower 2 miles they are from 10 to 30 feet thick and rest on a bench of bedrock from 10 to 15 - feet above the present stream level. The gold in the gravel benches along lower Myrtle Creek has probably been largely introduced into them by that stream. However, the bench gravels of the Slate Creek valley have been found to contain gold at other localities, especially above Myrtle Creek, and it may be proved that these gravels are more generally gold bearing than the prospecting that has been done up to the present time has disclosed.

The future of mining on Myrtle and Slate creeks apparently depends on the application of hydraulic methods. The only hydraulic plant in the Koyukuk district is now installed on the east side of Myrtle Creek about $1 \frac{1}{2}$ miles above its mouth. The dam of this plant is built on the lower end of claim No. 12, and water is conveyed therefrom by a ditch about $1 \frac{3}{4}$ miles long, 3 to 5 feet wide, and 2 to 3 feet deep, dug along the east-side bench to a penstock on the upper part of bench claim No. 6. The fall of this ditch is about 30 feet from the dam to the penstock, or more than 15 feet to the mile. This is a rather steep grade for a ditch of this size, the usual practice in Alaska being to dig such ditches on a grade of 5 to 6 feet to the mile in good ground and about 3 or 4 feet in frozen muck, and smaller ditches with not over 7 feet fall to the 
mile. Larger ditches should be built with less grade. Careful work with an ordinary carpenter's level will enable the miner to locate a ditch to a desired grade with not more than 1 foot of error to the mile.

The Myrtle Creek ditch was dug during the summer of 1908, while the pipe, monitors, and lumber for the plant were brought up Koyukuk River to Coldfoot. 'This material was sledded about 9 miles with two horses from Coldfoot to Myrtle Creek during the winter of $1908-9$, and the plant set up during the early part of the summer of 1909. Water was turned on in the middle of July, and some trouble was experienced by the ditch breaking out in places where it was dug through frozen muck. These places had to be flumed with lumber, and after this was done the ditch carried water well, as most of it has good gravel banks. The head of water furnished to the upper monitor from the penstock is about 70 feet. If the ditch were rebuilt with a grade of about 6 feet to the mile from the dam to the penstock, a head of about 90 feet from the penstock to the monitor as it was placed in 1909 would be furnished instead of 70 feet. A pit about 200 feet.long, 100 feet wide, and from 15 to 20 feet deep was opened in the bench gravels at this place.

The Myrtle Creek gold is of the size that the miners call shot and wheat gold. It is coarse, clean, and hammered flat to some extent. Some of it is of the size and shape of melon seeds, and nuggets up to the value of $\$ 20$ are occasionally found. No doubt many of the finer particles of gold are not-recovered, as amalgamation plates are not used. The gold rests principally near the bottom of the gravels and in the crevices of the slabby schistose bedrock, which stands on edge and is loosened with picks and shoveled into the sluice boxes after the upper part of the loose gravel has been moved aside.

OLARA GULCH.

Clara Gulch is a short tributary on the east side of Middle Fork that drains the southwest end of the high mountain ridge which separates Myrtle and Marion creeks. It is about 3 miles long, and little more than a mile from Coldfoot. The gravels in this gulch were mined for gold in 1900 and 1901 by half a dozen men; who obtained returns of several thousand dollars.

KELLY GULCH.

Kelly Gulch is a short mountain tributary on the west side of Middle Fork, about 2 miles in a direct line above Coldfoot. About $\$ 500$ worth of gold was mined from it in the fall of 1901 . 
MARION CREEK.

Marion is an east-side tributary about 4 miles long that joins Middle Fork about 4 miles in a direct line above Coldfoot. Although it is a large stream and easily accessible, no systematic prospecting has been done upon it, probably because it carries a large quantity of water, and its gravels are not shallow enough to encourage summer work with pick and shovel, and because the district has not advanced. far enough in developing winter methods of prospecting with the aid of steam boilers for thawing and sinking in frozen ground to enable the presence or absence of gold in paying quantities to be satisfactorily determined.

Colors of gold are said to occur near the surface of the gravels in this valley. Attempts made during the winter of 1900-1901 to sink holes to bedrock with the aid of wood fires are reported to have been unsuccessful, but in the winter of 1908-9 several men renewed prospecting on this stream about 6 or 7 miles above its mouth, with the aid of a boiler. Bedrock was struck at a depth of about 26 feet, and good prospects are said to have been found. The only result from this work, however, appears to have been the locating of all the placer ground on Marion Creek in the form of 160-acre association claims by a few individuals, who are not real prospectors or miners, but who belong to that speculative class found in all the mining communities of Alaska, who take advantage of the loosely interpreted placer-mining laws of the United States.

EMMA CREEK.

Emma Creek is on the west side of the river directly opposite Marion Creek. Its basin is bounded from south through west to north by a high semicircular divide that rises from 3,000 to 4,500 feet above the Middle Fork in the short distance of 5 to 7 miles, thus giving this basin very steep grades, the average fall being more than 500 feet to the mile, with the result that all the streams within the basin are swift.

At the mouth of its basin the main stream, the confined accumulation of a considerable drainage area, has cut a canyon about 100 feet deep and half a mile long through crystalline limestone and schist into the bottom of an older, wider valley. The Emma Creek valley appears to have been a hanging valley that has been partly dissected, but not enough to obliterate its older configuration altogether.

Some gold has been found in scattered patches of older stream gravels on top of the rock walls of this canyon, but most of the placer gold has been concentrated in the gravels that have choked into the wider funnel-like expansion of the valley at the upper end 
of the canyon, the narrow gorge of the canyon, and the upper part of the gravel fan at the lower end of the canyon, where the swift stream has dumped its gravel load into the valley. of the Middle Fork. Both the funnel entrance at the upper end of the canyon and the bottom of the canyon are clogged by numerous large bowlders from 3 to 10 feet in diameter. Thus the canyon is a great natural sluice box, with bowlder riffle blocks, through which a tremendous quantity of gold-bearing gravels from the upper Emma Creek basin has been sluiced during a long period of rapid erosion. Without doubt this is the reason why the richest diggings have been found just above the canyon, in it, and just below it. The richest claim has been that at the mouth of the canyon. The upper basin of the creek may be compared to the pit, the canyon to the sluice boxes, and the gravel fan below the canyon to the tailings and dump of an artificial hydraulic mining plant, due allowance being made for the lack of efficiency of the canyon as a sluice with riffles because the ravement of bowlders is not close enough to arrest all the gravel and gold.

The rich placers of Emma Creek were first worked in 1900 and the largest production was attained in that and the two following years. Since then the locality has not been worked so extensively but has produced some gold each summer. The number and large size of the bowlders prevent it from being ideal ground for pick and shovel work. The total production of this stream for the 10 years $1900-1909$ is said to be about $\$ 160,000$.

A few miles above Emma Creek on the west side are two small gulches, Sawyer and Moose, which are reported to contain prospects of gold, but they are full of large bowlders and have not been worked.

\section{WISEMAN CREEK.}

Wiseman Creek is a west-side tributary that flows into Middle Fork about 16 miles by the course of the river above Coldfoot. It is a comparatively small stream occupying a large, broad valley bounded by mountains that rise over 2,000 feet above it on both sides. The bottom of this valley is filled over a width of half a mile by deposits of gravel, sand, and silt from 200 to 300 feet thick. These unconsolidated deposits extend more than 6 miles from the mouth of the stream to a point near its head and also for more than 2 miles up Nolan Creek, its principal north-side tributary. The Wiseman basin is the best example in this district of the results of a former drainage system which filled most of the deep secondary valleys with thick deposits of gravels, sands, and clays. The streams that have since occupied most of the valleys that were thus filled have been vigorous enough to carry away a large part of the unconsoli- 
dated deposits, but Wiseman Creek is an exception, for it is not large enough to clear its valley of the sediments which fill it, although its elevated position with reference to Middle Fork would be favorable for such a result. In this respect Wiseman Valley is in direct contrast to the basin of Emma Creek, previously described.

Although Wiseman Valley has been located for placer mining throughout its length and width, and even far up on the high, sloping benches along its mountain sides, there has been no mining development of this ground. All the locations were made without any discovery of gold on the land. This was done on the assumption that because gold was known to occur in Nolan Creek, one of its tributaries, it might be expected to be present in the deep deposits of the main valley. Only one prospect shaft has been put down to bedrock in Wiseman Valley. This work was done during the winter of 1908-9, about a mile below the mouth of Nolan Creek. The shaft is 260 feet deep. In going down it passed through 40 feet of vegetable muck, 180 feet of tough blue clay that had to be chopped with an ax, 30 feet of stream-washed gravels, and 10 feet of ground-up black slaty country rock mixed with some gravel. The shaft is dry. Colors of gold are found at the bottom of this shaft and all through the 30 feet of washed gravels, but are not considered to be present in large enough quantity to make the ground at present profitable for drift mining.

During the winter of 1909-10 another attempt was made to reach bedrock on Wiseman Creek. A depth of 335 feet was attained and a pipe driven 30 feet deeper without reaching bedrock.

\section{NOLAN CREEK AND TRIBUTARIES.}

General features.-Nolan Creek, a north-side tributary of Wiseman Creek, is about 4 miles long. The bedrock form of its valley is of the mountain-gulch type, and from a point about 2 miles above its mouth to its head it is still narrow and primarily a bedrock valley. In fact this steep-sided $V$-shaped bedrock valley continues nearly to its mouth, but this would not be apparent if it were not for the information disclosed by mining operations. For 2 miles above its mouth the valley is deeply filled with unconsolidated deposits of glacial silt, the surface of which presents a gradually widening flood plain that slopes gently downstream to join the still wider flood plain of Wiseman Valley. (See Pl. IX, $A$ and $B$.)

Nolan Creek and its east-side gulches-Smith, Archibald, and Fay-are the important streams of the district at present, because it is along them that the rich gold-bearing gravels have been found and actively mined. The placers within the Nolan Creek basin are of three classes-bench gravels, shallow gulch gravels, and deeply buried frozen gravels. 


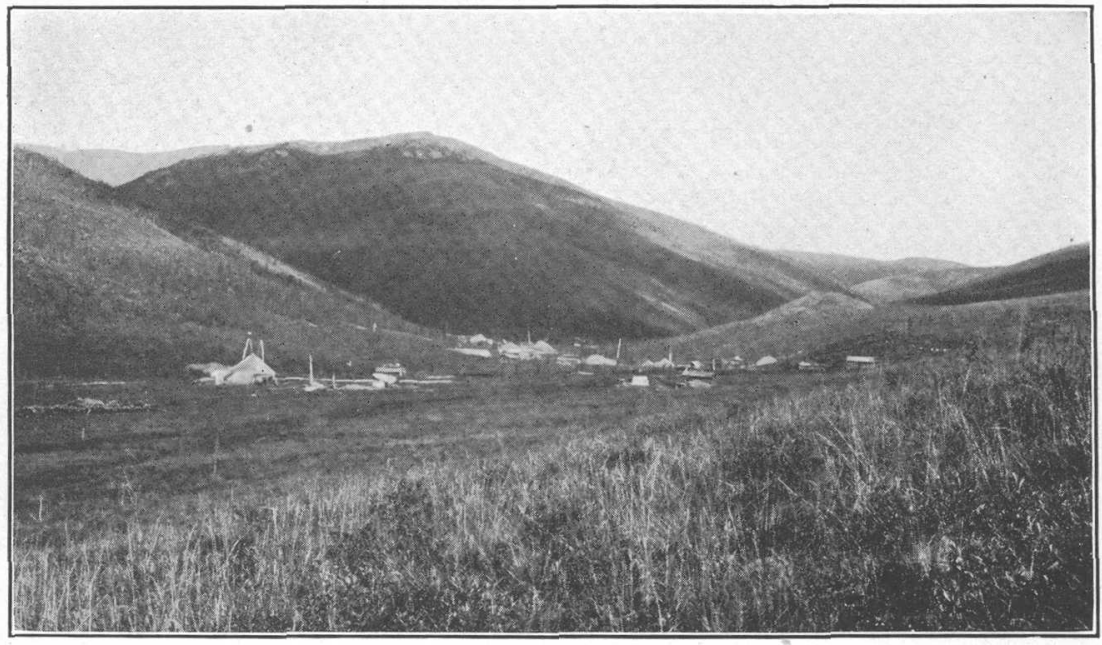

A. NOLAN CREEK VALLEY, SHOWING PRINCIPAL MINING PLANTS.

Looking upstream from east side of the valley opposite claim "No. 6 below."

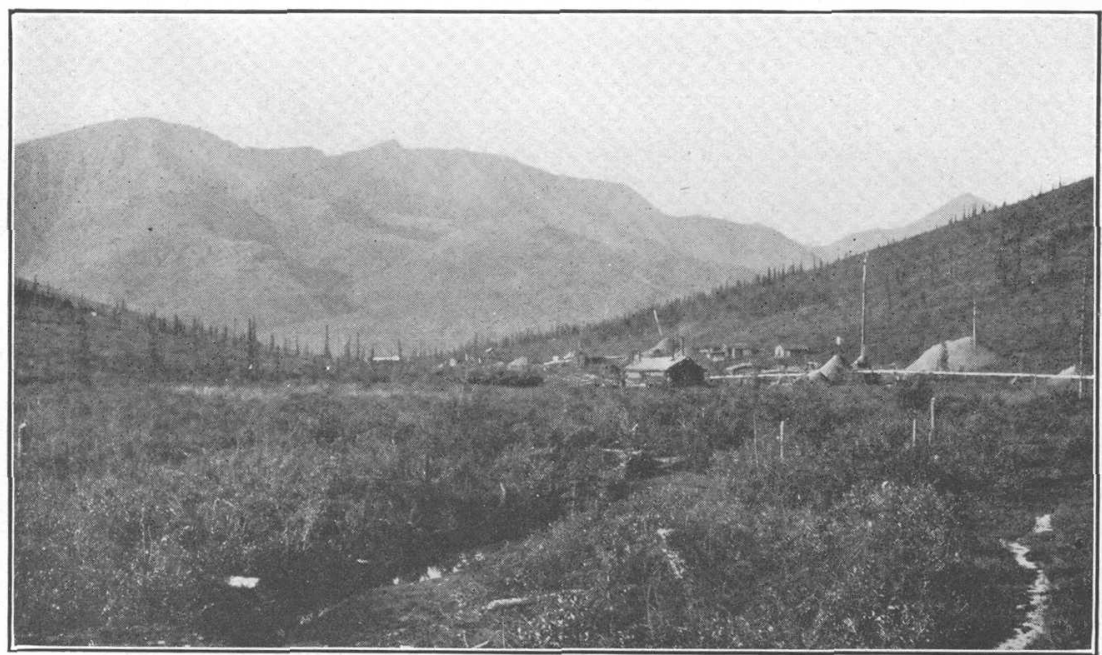

B. NOLAN CREEK VALLEY, SHOWING BOILER HOUSE AND DUMPS.

Looking downstream from upper end of claim "No. 3 below." Mountains forming south slope of Wiseman Valley in background. 
Bench gravels.-The character of the bench deposits along Nolan Creek valley suggests that they may be remnants of narrow, crudely washed beaches formed along the mountain sides when the Nolan Valley was an arm of a glacier-dammed lake which occupied the Wiseman Valley. They appear to mark places of rest occupied by the lake at different stages of level. Those that have been found to contain gold in paying quantities are situated from 50 to 200 feet above the present valley floor between Smith and Fay gulches, through a distance of about $1 \frac{1}{2}$ miles. They have been prospected and mined to a moderate extent but are difficult to work to advantage because of an inadequate supply of water for cheaply groundsluicing away the frozen clay and vegetable muck that cover the washed gravels.

Shallow gulch gravels.-There is not much shallow gold-bearing gravel in the valley of Nolan Creek. What there is appears to be confined to the tributary gulches. The discovery of gold in 1901 in shallow gravels on Fay Gulch a short distance above the point where it joins Nolan Creek first aroused interest in the search for gold within this drainage basin and caused its unconsolidated deposits to be located for placer mining, but actual mining was not actively begun until 1903, when the small amount of shallow ground on Fay, Archibald, and Smith gulches was worked. The lack of boilers and other necessary equipment for steam thawing delayed the investigation of the deep placers for several years. Some work of this kind was attempted with wood fires, however, that resulted in 1903 in the mining of ground from 15 to 25 feet deep on Smith Gulch and on Discovery claim on Nolan Creek at the mouth of Fay Gulch. From 1903 to 1905 Smith Gulch, Discovery claim on Nolan Creek, and claims Nos. 1 and 2 on Fay Gulch yielded considerable gold; but not until 1905-6 were the deeper gravels in the bed of Nolan Valley itself demonstrated to be rich.

Deep frozen gravels.-By far the largest bodies of gold-bearing gravels in Nolan Valley are deeply buried beneath frozen silts and clays. By 1906 several boilers and some steam thawing equipment had been brought to Nolan Creek, and in this year the first successful prospect shaft in the valley was sunk 135 feet to bedrock on the lower end line of claim No. 3 below Discovery. Rich gold-bearing gravels were found at the bottom of this shaft, and since that time placer drift mining in the deep frozen deposits of this valley has been actively conducted by about 100 men.

Up to the present time the most productive ground on Nolan Creek has been found to extend from Discovery to claim "No. 6 below," a distance of about 13 miles. The creek extends to claim "No. 8 below," half a mile farther, where it joins Wiseman Creek. 
There are also six claims above Discovery, but little gold has been mined above Fay Gulch, which joins Nolan Creek on Discovery claim. The depth of the unconsolidated deposits increases downstream from 20 or 25 feet on Discovery to 180 feet at the mouth of the creek on claim "No. 8 below." This increase is gradual, the depth being from 40 to 70 feet on claims Nos. 1 and 2, 135 feet on No. 3, 155 feet on No. 5, 165 feet on No. 6, 170 feet on No. 7; and 180 feet on No. 8 below Discovery. However, the general configuration of the bedrock is not so regular as these figures indicate, for underground drifting shows that there are considerable irregularities, called "drop offs" by the miners, especially across the bed of the valley. Besides these irregularities of the bedrock surface of Nolan Valley, it carries in many places numerous bowlders, some of them of large size, between which the gold-bearing gravels have lodged. Here and there these bowlders separate the gravels into patches of greater or less extent and, together with the "drop offs," make the work of drifting along the bedrock more uncertain than if the gravels were of uniform size and more evenly distributed, as they are in the Fairbanks district.

Character of gold.-The placer gold from Fay Gulch and the upper part of Smith Gulch, where it appears to be near its bedrock source, and probably has not been carried far, is mostly in the form of rough angular grains. That in Fay Gulch has about as much quartz attached to it as there is gold, the proportion being about half gold and half attached quartz. 'On Smith Gulch the gold is in more rounded and heavier pieces the farther downstream it lies. Some of the gold in Smith Gulch has a coating of white mineral matter, which the writer has not had opportunity to test, which is said to be lime, but may be some other mineral substance. This coated gold is most common 'toward the head of the gulch. Either it does not occur on the gold farther downstream or the coating has been worn off of it by travel. The gold from Smith Gulch is of very high grade, its assay value being said to be more than $\$ 20$ an ounce, which would class it with the highest-grade placer gold known.

The gold in the deep gravels along Nolan Creek is mostly in the form of rounded, smooth, heavy, chunky pieces. Large nuggets are rare; one of the largest, having a value of about $\$ 300$, was found on claim "No. 1 below," and another, with a value of about $\$ 120$, was taken from claim "No. 3 below."

\section{MINNIE CREEK.}

Minnie Creek is on the east side of Middle Fork opposite Wiseman Creek. Its valley is about 9 miles long and similar in form to that of Marion Creek, which is parallel to it on the south, the two being separated by a rugged mountain ridge about 4 miles broad that rises 
over 3,000 feet above the valley floors. The stream is of good volume, and its gravel deposits are similar to those in Marion Creek, containing considerable live water. The presence of this water in the gravels makes it difficult to sink prospect shafts to bedrock. The first hole to bedrock was dug in 1904, and about $\$ 500$ worth of heavy shot gold was taken from a short drift at the bottom before water drove the prospectors out. More prospecting was done in 1905 , but little has been done since. Two men mined about $\$ 400$ worth in 1906. No doubt this valley will be prospected more thoroughly as the development of the district progresses.

UNION GULCH.

On the west side of Middle Fork, between Wiseman Creek and Hammond Creek, two gulches-Union and Confederate-drain the east side of the mineralized mountain mass that lies between Middle Fork and Nolan Creek. The gravels in both gulches contain gold, but those in Union Gulch, the southern of the two, which is situated about 2 miles above Wiseman Creek, are the richer. Although the deposits on Union Gulch are limited to about one claim in extent, about $\$ 30,000$ worth of coarse gold has been mined from them. Gold was discovered on Union Gulch in 1901. The largest production was attained in 1902, but work is still being carried on there.

Prospects of coarse gold have been found on Confederate Gulch, but no mining has been conducted there.

HAMMOND CREEK.

Hammond Creek flows into Middle Fork from the northwest about 20 miles, by the course of the main river, above Coldfoot. It is the largest tributary of Middle Fork, being at least 45 miles long and discharging a volume of water equal to about one-fourth of the flow of the main river above the confluence. The Hammond Valley shows strong evidences of having passed through the same stages of drainage development as the smaller tributaries to the south. In modified forms it has bench and deep-gravel deposits and canyon features, somewhat similar to those that have been already outlined for Emma and Wiseman valleys.

Though the Hammond Valley has been prospected more or less throughout its lower 25 miles, gold has been mined only along the lowest part of its course, more particularly in several short gulch valleys tributary to it from the south within 5 miles of its mouth.

Hammond Creek first attracted attention in 1900, when reports of the discovery of coarse nugget gold in the gravels of the river about 2 miles above its mouth, together with verification of the news about Myrtle Creek, caused about 1,000 people to rush to the Koyukuk dis- 
trict from Dawson and other settlements on the Yukon. This enthusiasm soon subsided, however, because the diggings did not fulfill expectations.

As on all other streams where gold is discovered in Alaska, the unconsolidated deposits both along the present stream and on the benches of Hammond Valley have been located for placer mining.

Little systematic or continuous mining has been done on the present stream gravels of Hammond Creek, because the large flow of water and the presence of numerous cobbles and small bowlders make pick and shovel labor unprofitable. A wing dam was built on claim "No. 6 above" early in the spring of 1902, at a time of low water, to divert the river so that the gravels in its bed might be mined. Although the summer's work produced about $\$ 10,000$ worth of gold, the expense of the operation is said to have made the venture unprofitable. Only about $\$ 5,000$ or $\$ 6,000$ worth of gold has been mined from this claim since 1902. Spasmodic work from year to year along the banks of the river, chiefly on Discovery claim, has yielded from $\$ 8,000$ to $\$ 10,000$. Most of the gold has been of the coarse nugget variety, some pieces being of large size. One nugget having a value of $\$ 849$ was found on claim "No. 6 above," another worth $\$ 842$ was found on Discovery claim, and one worth $\$ 1,000$ and another worth about $\$ 1,100$ have been mined in this valley.

On Discovery bench claim, which is on the south side of Hammond Creek about $1 \frac{1}{2}$ miles above its mouth, several attempts to discover deep gold-bearing gravels in the frozen deposits were made without success. During 1909 two new shafts were sunk to bedrock on this claim. The first shaft is located about 350 feet south of the present channel of the river, which at this place is running against bedrock on the north side of the valley. At a depth of 66 feet this shaft reached bedrock, the surface of which was found to be sloping toward the north. A second shaft was sunk about 200 feet north of the first, where the bedrock surface is also about 66 feet down. Here the bedrock was found to be sloping to the south, toward the first shaft. In drifting southward along this bedrock surface it was found to have a grade of about 4 feet in a distance of 20 feet along the slope. From this it is concluded that an old channel of the river is situated between these two shafts. A drift on bedrock southward across the supposed old channel to the first shaft is reported to show the presence of gold in paying quantities, and during 1911-12 profitable mining has been conducted upon the deep channel gravels along this stream between Vermont Creek and its mouth.

GOLDBOTTOM, SWIFT, AND BUCKEYE GULCHES.

Along the south side of Hammond Creek, between the Middle Fork and Vermont Creek, are several gulches that drain the north face of 
the mineralized mountain mass which has been already referred to in describing the placers of Nolan Valley and Union Gulch and will be mentioned later in the discussion of Vermont Creek. The profitable ground on these gulches is near their mouths, where they have accumulated considerable washed waste from the mountain slopes to the south, more or less mixed with bench-gravel remnants of river deposits along the south side of Hammond Creek. The principal gulches are Goldbottom, Swift, and Buckeye.

Goldbottom Gulch heads against Union and Confederate gulches. About half a claim length, 600 to 700 feet of ground, at its mouth has proved fairly profitable to mine and has yielded between $\$ 5,000$ and $\$ 6,000$. In 1904 a $\$ 400$ nugget was found here.

Swift Gulch is a little larger than the others. It heads opposite Smith and. Fay gulches. Work on it at various times has yielded the equivalent of wages and occasionally a small amount of coarse gold. Some of the gold in this gulch is coated with white mineral matter like that on Smith Gulch.

Buckeye Gulch is a small tributary a short distance below Vermont Creek. Gold equal to the daily wage scale of the district-that is, from $\$ 6$ to $\$ 10$ a day to the man-has been occasionally mined from the claim at its mouth.

\section{VERMONT CREER.}

Vermont Creek is a small stream flowing into Hammond Creek from the south about 5 miles from the Middle Fork. It is formed by two branches, an east or left one, about 2 miles long, and a west or right one, about 3 miles long, which flow through deep gulch valleys that join about a mile from Hammond Creek. These gulch valleys head against similar gulches that are tributary to upper Nolan Creek and drain southward. By way of the east fork of Vermont Creek there is a pass through the mountains to a short gulch near the head of Nolan Creek. This pass is about 800 feet above Hammond Creek, or 2,900 feet above sea level. Some small spruce grows in this pass but becomes sparse on its bounding slopes.

The bedrock in Vermont Creek is the same as that already described as occurring in Nolan Valley. This carbonaceous phyllite formation extends northward through the mountains from Nolan Creek to Hammond Creek and is well exposed on the east or left fork of Vermont Creek and to the east of it for some distance. It also outcrops along the south banks of Hammond Creek for some distance downstream from the mouth of Vermont Creek, where much of it shows slaty cleavage. On the upper part of the east fork of Vermont Creek, where unweathered exposures may be observed, it is found to be mineralized with pyrite in the same manner as on Nolan Creek, and it is here that quartz veinlets along joint cracks may be easily seen.

$76032^{\circ}-$ Bull. 532-13-7 
One of the veinlets about 1 inch thick was observed to be mineralized by sulphides and free gold in flakes and specks. No doubt there are other veinlets so mineralized.

Placer gold was discovered on Vermont Creek August 25, 1901, and has been profitably mined there ever since. Discovery claim is located on the main lower part of the creek just below the forks. Two claims, covering about half a mile, on the east fork have been good shallow mining ground, and Discovery claim and the two claims below Discovery contain good values. Thus the rich gravels extend over five claims. for a distance of about $1 \frac{1}{4}$ miles, of which threefourths of a mile is below the forks and one-half a mile along the east fork. On the west fork of Vermont Creek gold has not been found in paying quantities. Claims "Nos. 1 and 2 above," about half of Discovery claim, and claim "No. 1 below" have been worked out. The gravels on the east fork average about 3 feet in depth and are not very wide, as the bottom of this gulch is narrow. On Discovery claim the valley bottom broadens and the gravels are from 200 to 300 feet wide. On claim "No. 1 below" their width increases to about 400 feet. The gravels become somewhat deeper on the lower end of claim No. 1 below Discovery and decidedly deeper on claim No. 2 below Discovery. In fact the lower half mile of Vermont Creek is flowing over deposits that may be more properly considered, at least in large part, to be bench deposits of Hammond Valley, for these deposits are not shallow gravels, largely unfrozen, lying on the bedrock floor of a narrow rock-cut gulch such as extends above claim No. 2 below Discovery, but are deep frozen accumulations. of gravel, sand, and clay that,are directly related to similar extensive bench deposits which occur along the sides of Hammond Valley. Although the largest part of the unconsolidated stream deposits on this claim belongs to the sediments of Hammond Valley, there appears to be little doubt that most of the gold in this deep ground has been derived from Vermont Creek.

About the center of claim No. 2 below Discovery, on Vermont Creek, a sinking and drifting operation in these deep frozen deposits has proved very successful. This work was begun during the winter of 1908-9. The shaft is about 90 feet deep. At a depth of about 50 feet it encountered a bed of cemented sediment 11 feet thick which is termed a "false bedrock." Below this hard bed is from 18 to 20 feet of clay, succeeded by 7 to 8 feet of washed gravel. In August, 1909, a drift about 200 feet long had been driven in a direction up Vermont Creek and another drift about 100 feet long across the direction of Vermont Creek.

The Vermont Creek gold is mostly coarse and rounded. Several nuggets worth more than $\$ 200$ have been found. 
Above Hammond Creek gold has not been found in paying quantities on any of the west-side tributaries of Middle Fork, nor is it known to occur on Dietrich River, the northernmost headwater branch of the Middle Fork, whose valley for the most part is cut in the limestone formation of the Bettles group, which lies northwest of the gold-bearing formations of the Koyukuk district.

From Hammond Creek to Gold Creek, a distance of 7 or 8 miles, the Middle Fork follows a course from northeast to southwest. Between the valley of Minnie Creek and this section of the Middle Fork valley there is a high mountain ridge similar to the ridge between Minnie and Marion creeks. All the southern slope of this mountain mass is drained by tributaries of Minnie Creek, while its northern slope is drained by a number of short, steep gulch streams that flow into the Middle Fork, and by Gold Creek, which flows around its northern flank. The principal short gulches between Minnie and Gold creeks that drain this mountain ridge, named from south to north, are Bluff, Rainbow, Montana, Coon, Nugget, and Sheep. They have been prospected more or less, and a little gold has been mined from the most northerly one, Sheep Gulch, on which, it is reported, two or three claims show good prospects and one small area yielded about $\$ 800$ worth of gold to the box length during the summer of 1908 . By "box length" is meant an area about 12 feet long by 16 feet wide, or a bedrock surface of approximately 200 square feet.

\section{GOLD CREEK.}

The present form of the valley of Gold Creek apparently shows that it has passed through a series of drainage changes somewhat similar, but of modified form, to those that have taken place in the development of the basin of Emma Creek, but as it is impossible to describe these changes clearly without illustrating its features by a detailed topographic map, only an outline will be given here.

The most marked feature that this valley now presents is a canyon section $1 \frac{1}{2}$ miles long in its lower part, which is cut at right angles across a sloping bench of bedrock on the east side of the valley of Middle Fork. One mile above the mouth of Gold Creek this narrow canyon is 50 feet deep and its depth increases upstream for about half a mile, reaching 200 to 250 feet. In its upper part, where deepest, it appears to have cut down through a spur that slopes from the mountain mass which lies on the south between Gold Creek and Sheep Gulch. On the north wall of the canyon, in line with this mountain spur, there is a small but prominent bedrock knoll that appears to be a remnant of the mountain spur on the south side of 
the canyon. Just above or northeast of this knoll, in the bedrock of the north wall, there is a depression about 50 feet deep and 300 feet wide, the bottom of which is about 200 feet above the present bottom of the canyon. This depression is filled with stream-washed channel gravels which in their present position are resting on top of the canyon wall. These washed gravels appear to occupy a part of a former channel of Gold Creek when it flowed at a level 200 feet higher than it does now. The significance and probable course of this old high channel will be discussed later in connection with the gold placers that occur on Linda Creek, with which it appears to be closely related.

The fall of Gold Creek from the head of its canyon to its mouth is about 200 feet in a distance of less than 2 miles. Above this canyon the valley widens out somewhat and has a deep $V$-shaped cross section whose slopes rise steeply to a height of about 1,000 feet above the creek. At this elevation, which is about 3,000 feet above sea level, the steep lower slopes form a shoulder, with more gently inclined slopes on the higher parts of the mountains (see Pl. VII, $B$, p. 58)-that is, the present valley of Gold Creek shows strong evidence of having been rather abruptly cut down into an older land surface which had a moderately rolling mountain relief that was much less rugged than the topographic form of this region to-day.

This deep V-shaped portion of the valley extends upstream from the head of the canyon for about 3 miles, and in this distance the fall of the creek is about 400 feet. About midway of this stretch and also at the upper end of it there are two more contractions in the valley, where the creek runs through short, low-walled, narrow gorges or small canyons. The halfway gorge appears to be caused by the presence of a hard dike of intrusive diorite which outcrops on the north slope of the valley and whose greater resistance to erosion over that of the softer schists on both sides of it has offered a barrier to the down cutting of the stream. The uppermost gorge, about a mile farther upstream, is cut through a low ridge of schists that are harder than the surrounding schists. This barrier rises about 60 feet above the present creek bed. Thus the lower half ( 4 or 5 miles) of Gold Creek valley has three contracted features, the first and deepest of which is a canyon, the second and third gorges. Between these three contracted features there are two wider Vshaped portions of the valley and it is in these portions that the richest gold-bearing gravels have been found and mined.

Above the upper gorge the upper half of the Gold Creek valley is wider and has a form entirely different from that of its lower half; there are no canyon-like contractions, and instead of a sharp deep V-shaped cross section it has more open and gradually sloping sides. This form continues through 3 or 4 miles to its headwater gulches. 
The country rocks of the Gold Creek valley are practically all schists. The outcrops in the lower half of the creek are mostly' of the carbonaceous phyllite schist that occurs in the basins of Wiseman Creek and Hammond Creek, already described; in the upper half of the valley the bedrock is mostly of the micaceous quartz schist variety that occurs to the south, in the Myrtle Creek basin.

The diorite dike that forms the gorge about $1 \frac{1}{2}$ miles above the canyon is the only intrusive rock seen in place. Large hard bowlders of this dike rock are common in the creek wash, from the dike down to the head of the canyon, and as bowlders of this rock were not observed above the dike it seems that they are mostly if not all derived from this dike and that this dike is the principal occurrence of igneous rock in the valley. On the mountain ridge that bounds upper Gold Creek valley on the northwest there is a considerable mass of limestone of the Bettles group that forms the top of a mountain 3,900 feet high, and from the presence of a considerable number of cobbles and small bowlders of crystalline limestone in the creek wash it may be concluded that considerable of this limestone formation, which overlies the schists and was probably at one time much more extensive in distribution, has been eroded away.

The probable bedrock source of the gold in this valley is not so evident as it is in those of Nolan and Vermont creeks, but there are indications of a pyrite mineralization of the phyllite schist bedrock in the vicinity of the diorite dike on lower Gold Creek. Whether this dike has had anything to do with the primary introduction of gold-bearing minerals at this place is not known. As the influence of igneous intrusives is so common a phenomenon in other parts of Alaska it is fair to presume that it may have been exerted here.

Placer gold was discovered on Gold Creek in 1900 and has been mined more or less throughout 6 miles of its length from claim No. 4 below Discovery, at the head of the canyon, to claim "No. 19 above," on its headwaters. The most profitable diggings have been the shallow stream gravels that occur in the two sections of the valley situated between the canyon and the middle gorge and between the middle and upper gorges. The claims located between the head of the canyon and the middle gorge are designated Discovery, Nos. 1 to 4 below Discovery, and Nos. 1 and 2 above Discovery. Between the middle and upper gorges the claims are Nos. 3 to 6 above Discovery.

No mining of consequence has been done below claim "No. 5 below," in the head of the canyon. In 1903 this claim is said to have yielded gold equal to $\$ 12$ a day to the man, or the daily wage at that time.

Claims "Nos. 3 and 4 below" are reported to have yielded during 1901-2 over 100 ounces of gold, or about $\$ 2,000$ worth, and this 
ground has been worked since then somewhat regularly, with about the -same yearly production. Most of this mining has been done in the winter by thawing with wood fires and drifting into a low bench of frozen gravel and earth on the north bank of the creek.

Discovery claim is reported to have yielded in 1900 about $\$ 85$ a day to the man, and work on this claim was continued until 1904, when the good-paying ground was about exhausted. The gravels of this claim were shallow and easily worked, especially toward its upper end, where they were richest. About $\$ 15,000$ is reported as the production for 1901 and about $\$ 85,000$ is stated to be the total production of this claim.

In 1901, besides Discovery, claims "Nos. 1, 3, 4, and 5 above" were actively mined. "No. 1 above" is said to have paid a little better than wages and to have produced a net profit of about $\$ 4,000$ while it was mined. "No. 2 above," the upper part of which is in the halfway gorge, did not prove very good and yielded only from $\$ 4$ to $\$ 8$ a day to the man. Claims "Nos. 3 and 4 above" and the lower two-thirds of "No. 5 above," which are situated between the two gorges, were very good producers. The creek gravels were shallow and easy to handle. No definite figures of the amount of gold mined are available, but it is reported to have been as much as that of the claims located between the halfway gorge and the canyon.

Claims "Nos. 6 and 7 above" have produced very little. No. 8, which is above the upper gorge, is reported to have produced $\$ 500$ to the box length for a short distance. Two men mined a few hundred dollars' worth of gold from it in 1909 . Only a very little prospecting and assessment work has been done on claims "Nos. 9 to 17 above."

In 1909 four men were mining with picks, shovels, and sluice boxes on claim "No. 18 above" and were producing about $\$ 10$ a day to the man. "No. 19 above" is said to have produced $\$ 500$ to the box length in 1904. Two men were working on this claim in 1909, but the returns were not very profitable:

Most of the placer-gold deposits on Gold Creek are shallow stream gravels without any large amount of overburden. For this reason it has been one of the best valleys for pick and shovel mining in the district. Some of the gold on claim "No. 19 above" and in the gulches near by consists of rough, light pieces that appear not to have been transported far from their bedrock source', but most of the gold has the form of rounded shotlike pieces and small, smooth nuggets.

LINDA CREER.

Linda Creek is a small stream about 4 miles long that drains the southern half of a gravel-filled depression on the east side of the Middle Fork about a mile north of Gold Creek. The part of this wide depression occupied by Linda Creek is the southwesterly arm 
of a semicircular bend east of a mountain 3,000 feet high, which stands isolated from the main mountain ridges that bound the valley of Middle Fork. Linda Creek heads in the elbow of this bend in a large pond which, with several other smaller ponds, occupies a flat gravel and silt covered watershed between Linda Creek and another small creek of about the same length that drains the northwesterly arm of the depression and flows into Middle Fork about 6 miles above the mouth of Linda Creek. Over the broad bottom of this depression throughout its extent is spread a covering of waterworr gravels and silts, over which flow the creeks that drain its arms, but at about the middle of their. courses these creeks have washed through the unconsolidated deposits and cut shallow channels into the underlying bedrock. Linda Creek, however, has done practically no bedrock cutting and does not occupy a valley of its own making, and it appears evident that any placer gold now occurring in the gravels of its channel must have been introduced there by some agency other than the present stream.

The most probable source for the placer gold that has been found on Linda Creek is Gold Creek. In the description of lower Gold Creek the stream-washed deposit of gravel about 200 feet above that stream on the north wall of its canyon was referred to as having a possible intimate connection with the placer gold that has been found on Linda Creek. The gravels on top of the canyon wall occupy a depression in the bedrock about 300 feet wide and 50 feet deep, and the exposure has every appearance of being a cross section of an old high channel of Gold Creek before that stream was diverted down its present canyon. If the rock knoll that forms the west side of this depression in the north wall of the canyon is, as it appears to be, a remnant of a former continuation of the mountain spur opposite it, on the south wall of the canyon, then the most natural course for Gold Creek to have followed when at this higher level would have been to the north toward Linda Creek, across the sloping bench that now intervenes. The direct distance across this bench between the high gravels in Gold Creek canyon and the locality where placer gold occurs on Linda Creek is a little more than a mile and the fall of the surface is about 300 feet. The indications that a stream flowed between these two points are not particularly marked. There is no strong surface evidence of a former channel unless a slight depression or sag of the surface, from 300 to 600 feet wide, indicated by a timberless strip overgrown with moss and dwarf willows, is considered to mark a frozen channel that is too cold to foster a good stand of timber such as now grows along both sides of it. This barren strip of land seems to connect the high gravels on the canyon wall with the placer-gold locality on Linda Creek, but whether it is the course of an old channel can be proved only by prospecting, and even if 
this is proved it may not be found to contain gold, especially throughout its length.

Gold is said to have been first found on Linda Creek in 1901. The only ground that has been mined is on Discovery claim, situated about half a mile above its mouth, and only the lower half of this ground has proved very productive, $\$ 18,000$ worth being mined from it in 1902. The gold is similar to that of Gold Creek.

BETTLES RIVER AND TRIBUTARIES.

Bettles River is the large eastern headwater branch of the Middle Fork of the Koyukuk. Its basin extends over 30 miles from east to west and 25 miles from north to south, in a region of rugged mountains between the Middle Fork and upper Chandalar River. Its longest and largest tributaries flow from the north out of mountains composed largely of the crystalline limestone that overlies the gold-bearing schist formations. Its southern tributaries are shorter and flow almost wholly over the same schist formations that extend to the south from Gold Creek to Slate Creek. This valley was not visited by the writer. The information given here is taken from the report by Schrader and notes gathered from prospectors who have worked on the creeks in this basin at various times from 1900 to 1909 .

In 1899 a United States Geological Survey expedition in charge of F. C. Schrader traveled through this valley, mapped it, and noted its principal geologic features. Schrader describes a more or less mineralized belt associated with a dioritic intrusive mass on Horace Mountain, on the west side of Robert Creek opposite Sheep Creek, but no valuable mineral deposits or rich gold placers have been found there so far. Prospects of gold are found, however, and small amounts have been mined on some of the tributary streams that have eroded into the underlying schist formation.

Emory Creek is a short south-side tributary of Bettles River that joins it about 8 miles above its mouth. It is about 3 miles long and heads north of and opposite claim No. 8 on Gold Creek. It is said that a total of about $\$ 10,000$ worth of gold has been mined from the gravels of this creek. The gold occurs on bedrock among bowlders which must be rolled aside to get the gold. Most of the mining was done several years ago. Only one man was working there during 1909.

Garnet Creek is a south-side tributary about 5 miles long, 18 miles above Middle Fork. It is reported to have yielded $\$ 7$ to $\$ 9$ a day to the man several years ago.

Mule Creek is a small north-side tributary opposite Garnet Creek. It heads in the limestone formation but has cut down into the underlying schists on its lower course. On a low bench about $2 \frac{1}{2}$ miles above its mouth good prospects have been found at a depth of 8 feet 
and $\$ 80$ was produced here in 60 hours' work. About $1 \frac{1}{2}$ miles above its mouth gravels 2 feet deep yielded a dollar an hour to the man. Small nuggets of native silver and nuggets of copper as large as 7 pounds have been found on this stream.

Prospects of placer gold have been found on a number of other creeks about the headwaters of Bettles River, namely, on Eightmile, Phoebe, Spruce, and Sheep creeks, and especially on those tributary to Robert Creek, which is the principal headwater branch of Bettles River. The gold is found on the lower parts of the tributaries to Robert Creek, where they cut down into the schist beneath the massive limestones.

Except on Emory Creek only prospect work has been done on all the streams tributary to Bettles River that have been mentioned.

SOUTH FORK OF ROYUKUK RIVER.

general FEATURES.

The South Fork of the Koyukuk is one of the largest and longest branches of that river. It rises about 10 miles west of Chandalar Lake, just south of the headwaters of Bettles River, and flows southwestward for about 175 miles. Its general course is parallel to that of the Middle Fork throughout its length. At no place are the main channels of these two rivers more than 25 miles apart, and at one place a few miles below Tramway Bar their main channels approach within 7 miles of each other.

The three large tributaries to the South Fork, Fish Creek, Jim River, and Mosquito Fork, all flow from the east, where they have their sources in mountains from 4,000 to 5,000 feet above sea level. These mountains are made up of the schistose formations that compose the wide belt of metamorphic rocks between Dall and Jim rivers. These three streams head against the headwaters of Dall and Hodzana rivers, and of West Fork and Crooked Creek, west-side tributaries of the Chandalar. Some prospecting for placer gold has been carried on within the valleys of these streams at different times during the last 10 years, but though prospects are reported to be widely distributed no mining has been undertaken.

In 1909 the Geological Survey party panned the gravels on the upper part of the south branch of Jim River and found colors of gold. The stream on which these colors of gold were found has been named Prospect Creek. (See Pl. I, in pocket.)

GOLD BENCH AND VICINITY.

The best-known placer-gold locality in the valley of the South Fork is named Gold Bench. Here there is a deposit of high-stream gravels situated on the northwest side of South Fork about 10 miles south of the Tramway Bar bench on Middle Fork, and apparently belong- 
ing to the same class of deposits. It is usually reached by a trail about 8 miles long that leaves the Middle Fork near the halfway road house, 28 miles below Coldfoot, or 32 miles above Bettles.

The gold-bearing gravels lie on top of a sloping bench of thick unconsolidated wash deposits in a semicircular bend of the river. On the south side across the river these unconsolidated deposits rise to a height of 200 to 300 feet above the river. The surface deposits, in which most of the gold has been found, are mostly of fine washed stream gravels, composed largely of schist pebbles, a considerable amount of quartz pebbles, some of flint, and a few bowlders and cobbles of igneous rocks. The best gold-bearing gravels mined were from 18 to 24 inches thick, distributed over an area about three placer claims ( 60 acres) in extent. Most of the gold rested on a "false bedrock" of reddish sand from 2 to 12 inches thick, and the richest yield was obtained from an area 150 to 200 feet wide and about a quarter of a mile long. Some of this shallow ground was so rich and so easily handled that from $\$ 80$ to $\$ 90$ a day to the man was mined with rockers, and in 1900-1901 an extensive shovel and sluice-box operation is reported to have yielded $\$ 85,000$ worth of gold. The total production for Gold Bench is estimated to be about $\$ 150,000$.

In a few places deeper layers of the reddish sand with which paying quantities of gold were associanted were found from 6 to 8 feet beneath the surface. Shafts sunk into the bench deposits to a depth of 20 feet have failed to reach 'solid country rock, but some colors of gold are found scattered through the washed deposits, which are all crudely stratified and range from coarse to fine material, the finer fragments being mostly of flat bluish-gray schist.

The gold is in the form of fine, flaky, light, and very much flat. tened pieces, the largest of which had a value of $\$ 3.50$.

The bedrock source of the gold is not known. It may have been washed from the direction of Tramway Bar bench, as a low valleylike depression filled with channel-washed gravels extends from that direction, but it appears more probable that the gold may have come from the mountains that border the south side of the river opposite and for some distance above Gold Bench. These mountains are apparently formed of igneous rocks, largely diabases, which may bave intruded the schist formations with which they are associated, and it may be that these igneous rocks have an intimate relation with the origin of the placer gold. On the south branch of Jim River, where colors of gold were found on Prospect Creek, the mountains that form the north side of the valley appear to be made up largely of the same igneous rocks.

One of the best reasons for believing that the Gold Bench gold may be derived from the mountains that lie between the South Fork 
and Jim River is that placer gold is known to occur on some of the streams that drain from this group of mountains and also in other bench-gravel deposits on the South Fork above Gold Bench. Three of these bench deposits are named Ironside and Grubstake bars and Eagle Cliff.

Ironside Bar is a gold-bearing bench deposit about a mile above Gold Bench on the south side of the river channel, where prospects of gold have been found and a little mining has been done. Grubstake Bar is a similar deposit on the, northwest bank of South Fork about 9 miles above Gold Bench. The bench is low and was worked with sluice boxes in 1900-1901 by two men who obtained about $\$ 2,000$ worth of gold. Eagle Cliff is likewise on the northwest bank. of South Fork about 2 miles above Grubstake Bar. It is a deposit of well-washed gravels resting on top of a rock-cut bench from 10 to 12 feet above the low-water stage of the river. In 1899 it was mined with a waterwheel to raise water from the river for washing the gravels. The gold found here is coarse, rounded, and about the size of wheat grains. During 1910 about $\$ 1,500$ worth of gold was mined from these benches by four or five men.

DAVIS AND OTHER CREEKS.

Davis Creek is a stream about 5 miles long, flowing from the mountains about 4,000 feet high that lie to the southeast between South Fork and Jim River. It joins South Fork about 8 miles above Gold Bench and is one of the first known placer-gold streams in this valley. The bars at its mouth are usually dry, as the stream apparently sinks into unfrozen gravels, but there is a good flow of water above its mouth, where it has cut into thick deposits of washed gravel. A small amount of gold occurs in these gravels and they have been mined to a small extent at intervals for the last 10 years. It is reported that above Davis Creek there are prospects, but no good paying quantities of gold in several creeks flowing from the same mountains, and also on Wilson Creek, a north-side tributary to South Fork about 21 miles above Gold Bench. It is also reported that loosely scattered colors of gold may be found in the gravels along South Fork as far up as Boulder Creek, which rises opposite the upper basin of Slate Creek; but no mining has been done along this part of the river.

HEADWATÉRs OF GLACIER CREek.

Glacier Creek, a large north-side tributary of the upper South Fork, about 10 miles long, heads against Gold Creek and two south-side tributaries of Bettles River. Its main valley is so deeply filled with unconsolidated deposits that it has not been prospected. Gold was discovered in 1901 on its principal headwater branch, 
California Creek, and two of its tributaries, Jim and Boer gulches. Shovel and sluice-box mining operations have been carried on in a small way by several men each summer since 1901, but this work has never yielded much more than the equivalent of the current wages of the district and hence has not proved very attractive. Two men who were working on Jim Gulch during the summer of 1909 planned to carry on prospect work in some of its deeper frozen gravel deposits during the winter of 1909-10.

NORTH FORK OF KOYUKUK RIVER.

GENERAL FEATURES.

- The North Fork of the Koyukuk is a large stream that rises on the south side of the Arctic divide west of the head of Hammond Creek and drains a north-south valley over 60 miles long and from 10 to 15 miles wide that lies west of and parallel to the Middle Fork Valley. The upper part of the North Fork Valley is in mountains of the same limestone formation that occupies a wide belt north of Bettles River, extends westward across Dietrich River, and crosses Hammond Valley about 25 miles above its mouth. The southern half of the North Fork Valley is in the schist formations that underlie the massive limestones to the north. About halfway up the valley, some 35 miles above its mouth, are several small creeks that carry shallow gold-bearing gravels. The first discovery of gold in this valley was made on Washington Creek in August, 1902; in September of the same year gold was found on Mascot Creek, a short distance farther west. Supplies may be taken to this locality by way of the North Fork in poling boats, but the usual practice has been to use a winter sled route from the Middle Fork by way of Wiseman Creek, at the head of which there is an open pass about 800 feet above the main rivers. The distance from Nolan Creek on Wiseman Creek to Mascot Creek is about 10 miles.

Washington Creek, which heads against several of the lower westside tributaries of Hammond Creek, has not so far yielded enough gold to encourage serious mining operations, although some coarse smooth gold is found in its gravels.

MASCOT CREER.

Mascot Creek is the only stream in the North Fork basin that has been extensively mined. Its bedrock is a micaceous quartz schist and its gravels are shallow, being nowhere more than 3 feet and in some places but a few inches deep. While the gravels were not considered to be very rich by the miners, the ease with which they could be handled made the work very profitable, it being little more than equivalent to what is termed "cleaning bedrock" in an ordinary 
hydraulic operation. The gold rested mostly upon bedrock or in the lowest layers of gravel, and to some extent in the soft, decayed bedrock, which in places was removed to a depth of a foot. The gold mined was coarse-large nuggets, some worth $\$ 100$, being found. The ease with which these deposits could be handled made it possible to carry on the mining with a profit of about 70 per cent of the yield, and when the extremely high costs of that time are considered the operations on Mascot Creek may be said to be the most profitable that have ever been performed in the Koyukuk district.

Mascot Creek is a short stream. The ground that has been mined extends over 11 claims, or less than 3 miles in length, from claim No. 3 below to claim No. 7 above Discovery. Discovery claim was the best. It yielded about $\$ 13,000$ in 1903 , or a total of $\$ 25,000$ for that year and the two following. Claims Nos. 1 and 2 below Discovery are said to have produced a total of about $\$ 20,000$ each, and claims Nos. 1 and 2 above Discovery the same amount each. Claim "No. 3 above " yielded about $\$ 25,000$ in 1903 and a little in 1904 . "Nos. 4 to 7 above" produced the equivalent of wages. The gross yield of Mascot Creek up to 1909 was about $\$ 150,000$, of which $\$ 90,000$ worth was mined in the summer of 1903 and the remainder during the two following summers.

In 1910 mining was revived on Mascot Creek in a small way, on bench gravels situated along the right side of the valley about 60 feet above the stream, opposite claims "Nos. 1 and 2 below." About $\$ 2,000$ worth of gold was mined.

\section{WILD RIVER.}

Wild River enters the Koyukuk from the north about 13 miles below the mouth of North Fork. Its valley lies between that of North Fork on the east and John River on the west, but it is not so long or large as either of these streams. It is probably not over 50 miles long in a direct north-south direction, but the main stream is longer than this, because the lower half of its course is very winding. The upper part of the valley crosses the gold-bearing schist belt from 30 to 40 miles north of Koyukuk River, and small amounts of gold have been mined from three creeks lying in this schist belt. The first one of these creeks in upstream order is Birch Creek, an east-side tributary, from which about $\$ 10,000$ worth of gold was mined during 1905-6.

About 10 miles above Birch Creek the river flows from a lake, and on two small creeks that flow into this lake from the east some gold has been mined. The southern of these streams is named Lake Creek. In 1903-4 gold to the amount of $\$ 2,000$ was taken from a claim on one of its headwater gulches. The gold was coarse, some of the nuggets ranging in value from $\$ 90$ to $\$ 150$. 
Spring Creek is the next stream above on the same side of the lake. The claim that has been mined is located about 1 mile from the lake. It yielded about $\$ 5,000$ in 1907 , but the summer of 1908 was so dry that there was not enough water available for advantageous work.

\section{JOHN RIVER.}

John River is one of the largest northern tributaries of the Koyukuk, which it joins about 2 miles above Bettles. It is about 120 miles long and crosses the Endicott Mountains in a deep valley that has its head in a pass across the Arctic divide at an elevation of about 2,500 feet above sea level.

From 40 to 60 miles above its mouth this river crosses the southwesterly extension of the. Koyukuk belt of gold-bearing schist. North of this belt is the same massive limestone formation that overlies the schists on North Fork, Hammond Creek, and Dietrich and Bettles rivers to the northeast. Schrader has noted a zone of sulphide mineralization in this belt of schistose rock, and the localities where prospects of gold have been found and small amounts mined are in this belt. No gold-bearing deposits have been found north of this schist belt.

Crevice Creek, which lies in these rocks on the east side of the river, and Fool Creek and its tributaries, on the west side, are the only streams on which encouraging prospects have been found up to this time. About $\$ 1,800$ worth of gold was mined on Crevice Creek in 1904 and good prospects were found on Midas Creek, a tributary of Fool Creek, in 1905, but these discoveries have not led to further development.

\section{DALL AND HODZANA RIVER REGION.}

Considerable search has been made for placer gold in the valleys of Dall and Hodzana rivers and their tributaries. It is reported that some prospects have been found in this district, but so far as known no mining has been done on a commercial basis. Much of this field has not been examined, but the evidence in hand goes to show that the geologic conditions are not unfavorable to the occurrence of gold placers, and that further prospecting would seem to be justified.

\section{CHANDALAR DISTRICT.}

\section{GENERAL FEATURES.}

At present mining operations in the Chandalar Valley are confined to a rather small area whose central part is situated about 6 miles east of the upper end of Chandalar Lake. (See Pl. I, in pocket.) On the west this area is bounded by the north-south portion of the Chandalar Valley, on the north by a wide east-west valley now 
drained by Lake and Grave creeks, on the east by the headwaters of McClennan and Big creeks, and on the south by Tobin Creek. As thus limited the area is about 10 miles in extent from north to south and the same from east to west and embraces about 100 square miles.

The chief features of this area are a rugged mountain mass, whose peaks are from 5,000 to 6,000 feet above sea level, and whose slopes are steep and deeply dissected by gulch valleys. The streams of these gulches are Big Creek and its tributary headwater stream St. Marys, Tobin Creek, Bowlder Creek, Big and Little Squaw creeks, and Big and Little McClennan creeks. They flow from the mountains in various directions and have concentrated along their courses more or less placer gold which is without doubt derived from the mineralized country rock into which the gulches have been eroded.

In a broad sense the Chandalar district may be considered an easterly continuation of the Koyukuk district. The same country rocks occur in both in the sections where gold has been found, their kinds, condition, and general stratigraphic relations being similar throughout a belt some 10 to 20 miles wide that extends from southwest to northeast across the region. The auriferous mineralization in the particular mountain mass here under consideration appears to have been associated with intrusive rocks, which at this locality are mostly diorites. There are apparently several of these intrusive masses, and they seem to be more or less accordant with the general strike, from southwest to northeast, of the country rocks which they cut. There are evidences of quartz mineralization in the schistose country rock about the borders of the intrusive masses. Several of these quartz bodies are $4 \cdot$ to 6 feet or more wide in their thickest parts and are known to have a more or less connected linear extent of several thousand feet. The directions of these lode zones do not appear to conform to the structural trends of the country rock, but rather to lie across the strike at large discordant angles. In general they extend from east to west.

In addition to the larger quartz-lode zones there are a number of small lenses scattered about in apparently a disconnected manner and a considerable number of veinlets at some localities. In general the quartz appears to be best developed around the borders of the larger dioritic intrusive masses, and while there are dikelike bodies of the same intrusive rock extending out from the larger masses the quartz mineralization does not appear to accompany these to any extent.

\section{QUARTZ LODES.}

Recent prospecting appears to reveal four principal quartz-lode zones, which extend across this mountain mass with general eastwest trends in more or less connected form. It is thought that 
these are practically continuous zones of fractures in the bedrock, but that the deposition of vein quartz, at least of quartz carrying gold, is not necessarily continuous along their whole extent but appears to-occur more in the form of shootlike bodies. There is evidence that these zones have suffered shearing movements since some of the quartz was deposited along them, and it may be that the quartz is more or less cut off or squeezed out in places; also that the quartz was never deposited in a vein of more than a few inches thickness at other places. In some parts of these zones the fractured walls of country rock lie against each other, with practically no vein quartz deposited between their slickensided surfaces. In the larger bodies the quartz has been considerably crushed and recrystallized, which seems to indicate that considerable of the quartz was deposited before the latest shearing movements occurred.

The southernmost of these zones of more or less quartz-filled fractures extends across the upper part of Tobin Creek basin. The principal claims located in this basin are known as the Mikado group. To the east, in the valley of upper Big Creek, there is a body of gold-bearing quartz in the bed of the creek on Discovery placer claim, and a group of lode claims have been located along its westward trend, which extends toward the Mikado group in upper Tobin Creek basin. It is thought that these two groups of lode claims are along the same general mineralized zone, and that this zone may be continuous from the valley of Big Creek to the upper basin of Tobin Creek, a linear extent of 3 miles or more. Where shafts have been sunk along the quartz veins in Big and Tobin valleys it is found that they stand nearly vertical, their dip being $80^{\circ} \mathrm{N}$.

On the Tobin, Little Mikado, and Mikado claims of the Mikado group the quartz has been exposed by open cuts in six places over a distance of 3,000 feet, and in all of these the quartz near the surface contains rich values in gold. Considerable development work has been done on the Little Mikado claim of this group. At about 20 feet from its west end line a shaft has been sunk on the vein to a depth of about 100 feet. The average thickness of this vein is about 4 feet, although there are some contractions and expansions along it. At a depth of 100 feet it is 3 feet 10 inches wide. It is reported that average assays from the quartz removed in sinking this shaft give $\$ 112$ to the ton. In 1912 a tunnel was run on this claim to tap the vein upon which the shaft has been sunk. It is estimated that this tunnel will meet the vein in a distance of about 456 feet, at a depth of about 209 feet below the mouth of the shaft, which has already been sunk 100 feet. This tunnel is 4 by $6 \frac{1}{2}$ feet in cross section, and in September, 1912, had been driven 130 feet. Three men will continue it throughout the winter of 1912-13 under a contract which pays them about $\$ 8$ a day for their labor. 
Another zone of quartz mineralization lies about 2 miles north of the Mikado group. Three principal groups of claims are located along this zone. From west to east they are named the Kelty; Eneveloe, and Summit groups. The Kelty group is situated on the southwest headwaters of Big Squaw Creek and the Eneveloe group on the southeast headwaters of this stream. The Summit group extends along the divide between Big Creek and Little Squaw Creek. The veins along this zone dip about $65^{\circ} \mathrm{S}$.

A tunnel on a line separating First Chance and Last Chance claims of the Eneveloe group has been driven 165 feet, to a point where its face is 125 feet below the surface. It is expected that this tunnel will tap a quartz vein about 200 feet from its mouth. On the Last Chance claim there is a surface outcrup of quartz which is reported to assay $\$ 198$ to the ton. On the Woodchuck claim, which extends to the east from the Last Chance, a tunnel entrance has been opened on a vein of quartz that has a width of about 4 feet between welldefined walls. On the Eneveloe claim, which lies north of the Woodchuck claim, another body of quartz about 6 feet wide which carries considerable free gold has been prospected by three open pits.

On the Summit claim a shaft 54 feet deep has been sunk, and a tunnel has been run 72 feet along the vein. A sample from 5 feet of ore in the tunnel at a depth of 34 feet is reported to have assayed $\$ 54$ to the ton. In the tunnel the vein was found to be from $1 \frac{1}{2}$ to 2 feet wide, and one rich lens of ore was found. The vein on this claim has been uncovered in four other places by shallow openings.

A third zone of quartz mineralization extends across the valley of Little Squaw Creek about three-fourths of a mile north of the Eneveloe group. As in that group, the dip of the vein is about $65^{\circ} \mathrm{S}$. The principal claim, the Little Squaw, has a tunnel 87 feet long driven along the vein, reaching at its face a depth of 35 feet. About 50 tons of good ore are on the dump of this tunnel. Some of this ore has been run through a small stamp mill that has been erected near the mouth of Little Squaw Valley. It is reported that this ore assays $\$ 60$ to the ton and that $\$ 38$ to the ton of free gold was recovered on the plates of the stamp mill. A road has been built up the west side of Little Squaw Valley from this mill site to the Little Squaw claim.

A fourth group of lode claims is located on a zone of quartz outcrops about a mile north of the Little Squaw group. They extend across the west slope of the valley of Little Squaw Creek. Tunnels have been started on two of these claims.

The veins of the four belts of mineralization that have been located! in this district are composed essentially of quartz, and so far as they: have been developed appear to be chiefly of the fissure-vein type, although their form and extent as: well-defined continuous quartz.

$76032^{\circ}-$ Bull. $532-13-8$ 
bodies has not been conclusively demonstrated by the small amount of underground work done on them up to 1913. Further developments along the strike of the quartz bodies may show the veins in some parts of the fracture zones to be more like the kind termed stringer veins. This would not be surprising from the evidence of sheared displacements shown by the nature of the quartz that makes up the larger bodies which have been opened. However, so far as observed, the ore bodies are essentially fissure veins or shoots rather than stringer lodes.

A large part of the quartz is much crushed and recrystallized. Most of it is white in appearance, and composed of masses of interfering grains, without many cavities, into which crystalline prisms project. This massive quartz, however, has been much fractured into sheets, which, in general, lie parallel to the vein walls and each other. These sheets vary from an eighth of an inch up to several inches in thickness, and many of the thicker ones are broken into tablet-like pieces by cross fractures. Between the thicker sheets some of the thinner ones taper to knifelike edges, and many thin, small lenses of quartz occur along the fractures. Most of the fracture seams between the thin sheets and lenses of quartz would not be noticeable to the unaided eye if it were not for the presence of films of dark sulphides which are deposited along the fractures. In addition to the deformational sheeting of the quartz, which is apparently due primarily to shearing movements, there is some depositional banding present in the veins. These bands are fillings of quartz from 1 to 3 inches thick, which show quite perfect interlocking crystals along the centers of individual sheets: The evidence seems to indicate that they have been deposited along sheared fractures, whose faces have been sprung apart to the width of a few inches, instead of being closely appressed and slickensided by the shearing movements. None of these depositional seams appear to have been filled with the sulphide ores instead of quartz, although they are all open fractures in the older crushed and recrystallized quartz, which contains a considerable amount of the gold-bearing sulphides. This seems to indicate that much of the shearing has occurred since the sulphide minerals were first introduced. Many of the sheared faces of crushed and recrystallized quartz sheets show slickensided coatings or thin seams of sulphides.

The two most abundant gold-bearing sulphides appear to be sphalerite (zinc sulphide) and arsenopyrite (arsenical iron sulphide or mispickel). There are minor amounts of galena (lead sulphide) and stibnite (antimony sulphide), together with a little pyrite and chalcopyrite. All these sulphides are rather intimately associated with one another throughout the crushed, recrystallized, 
and sheared quartz. These minerals occur both as small aggregates and blotches scattered through the more massive tablets of the recrystallized quartz sheets and as films and thin bands along the fractures between the sheets, especially between the thinner sheets. Free gold in flakes and specks may be observed mixed with the sulphides and scattered about in the quartz. Neither the sulphide mineral aggregates or the free gold appears to occur in solid forms or chunks of large size.

Within about 75 feet of the surface the ore is chiefly oxidized and the gold is probably for the most part free. Probably below the depth of 100 feet the ores will be found in a less oxidized condition.

The arsenical pyrite (mispickel) will probably be found to carry the highest values in gold, but the sphalerite (zinc blende or blackjack) will probably be more indicative of silver. Until thorough mill tests of the ore are made it will be impossible to state the gold tenor of the average ore. Probably one-third of the sulphide concentrates in a mill run of much of the ore will be sphalerite (zinc sulphide), with arsenopyrite and galena second and third in abundance. The sulphides sphalerite and galena generally tend more to silver than arsenopyrite or pyrite.

There seems to be little doubt that the most promise for the future of the Chandalar district is in its quartz lodes, but it requires a much larger initial investment of capital to develop lode deposits than placers, especially in a region so remote as this, where even rich shallow placers that require very little capital or-machinery do not always yield adequate returns under present commercial conditions.

The Alaska Road Commission has taken steps to relieve the situation to some extent by laying out a winter sled trail from the settlement of Beaver, on the Yukon, over which supplies and machinery may be transported with greater facility than in the past. During the winter of 1909-10 a small prospecting stamp mill was hauled to Discovery claim on Big Creek, and an attempt was made to mine a quartz lode prospect on that claim, but this appears to have been discontinued. This mill has since been used for testing the ore from a vein on Squaw Creek.

PLACERS.

The placer gold in the gulches is without doubt derived from the erosion of the weathered vein material, and the fact that the placer gravels are not very rich, although they evidently represent the concentration of gold from the disintegration of a great thickness of country rock during a long period of erosion in a locality which does not appear to have been glaciated, may be used as evidence that the 
gold-quartz veins contain only small amounts of gold. This, however, is not borne out by assays of the ore, for some remarkably rich gold quartz has been found in the prospects that have been opened.

There has been a little placer mining in the Chandalar district in the last 10 years, but the value of the total production does not exceed $\$ 60,000$. Most of this gold has been taken from the head of Big Creek and from St. Marys Gulch. It is reported that in 1911 a shaft was sunk on Crooked Creek to a depth of 286 feet and one on Mammoth Creek to a depth of 172 feet, but that no workable placers were found. 


\section{INDEX.}

A. Page.

Amphibollte schist, distribution and character of -.....--- 39,40

Andesite on Kanutl River, character and distribution of -.-

Animals of the region

Archibald Gulch, gold deposits on

\section{B.}

\section{Basalt on Chandalar River, features} of

on Kanutl River, features of -- 57

Bergman group, correlation of --_-- 54-55 Bettles River, basin of, extent of _. 104 Bettles serles, correlation of -....... 52-53

Big Creek, gold deposits on_..._._ 112, 116 valley of, description of -._._._. 18-19

Big Squaw Creek, gold deposits on _- 113 Birch Creek, gold deposits on _..._. 109 Birch Creek schist, distribution and character of correlation of - . mineralization of _...- 47-49 structure of _...

Boer Gulch, gotd deposits on _..._ 107-108 Brooks, A. H., preface by_._.. 7-8 Buckeye Gulch, gold deposits on .... 96-97

\section{c.}

Callfornia Creek, gold deposits on - 107-108 Carboniferous rocks, age and correlation of -

distribution and character of _-- 51-52 Cenozolc rocks, nature and distr1bution of _._._._. 56-57

Chandalar district, gold in, distribution of _...... 110-111

gold In, lodè deposits of _- $75,111-115$ placer deposits of 115-116

Chandalar Lake, description of _- 17

Chandalar River, features of

lavas on _._.

rapids on, plate showing _..._.. 15

Fast Fork of, topography of -- 19

Middle Fork of, topography of _- 17-18

Chapman Creek, gold deposits on

Christian River, description of _...- 21

Clara Gulch, gold deposits on $\quad 89$

Climate, features of _._.______ 27-28

Coldfoot, situation of _._-_-_._-_. 86

Confederate Gulch, gold deposits on_ 95
Cretaceous rocks, distribution and character of _._._._. 54-55

Crevice Creek, gold deposits on._.-- 110

Crooked Creek, prospecting on_..- 116

D.

Dall River, description of -_._-_- 21-22 gold prospects on

Dall River area, rocks of, distribution and character of

Davis Creek, gold prospects on_..-- 107

Devontan rocks, distribution and character of _-_.- 50-51

Ditch, bydraulic, plate showlng -_-_ 86

Drainage, arrangement of _._._._._ 15-27

\section{H.}

Eagle Cliff, gold in

Eightmile Creek, gold prospects on

Emma Creek, gold deposits on _._- 90-91

Emory Creek, gold deposits on ...... $\quad 304$

Endicott Mountains, features of -.. 15 glaciation on - $60-66$ plate showing 15

B.

Fay Gulch, gold deposits on

Field work -

Fool Creek, gold deposits on

Fossils, occurrence of _._._._. 51, 52-53

Freight, rates for towing in scow, plate showing - $\quad 86$

G.

Garnet Creek, gold deposits on

Geology, map showing outline of stratigraphlc, section showing-- $\quad 34$ Gerdine, T. G., survey by Glaciation, on the Endicott Mountains, discussion of _- 60-66

Glacier Creek, tributaries of...... 107-108 Gold, discoverles of distribution of ...... 77-78 lode deposits of, in the Chandalar district._._- 75, 111-115 possibllity of, in the Koyuknk district 74-75 
Gold, occurrence of, in glacial gravels_ 65-66 placer deposits of, in the Chandalar district

115-116

in the Koyukuk district_- 83-110 production of 68-70 source of, in placers See also names of streams and localities.

Gold Bench, gold deposits on _-_- 105-107

Goldbottom Gulch, gold deposits on $-96-9 ;$

Gold Creek, geologic history of .... 99-101 gold deposits on valley of, plate showing 58

Gold Creek dike, description of _... $\quad 43$

Granite, weathering of, plate showing

wind erosion of, plate showing-

Grave Creek, topography of _._._. 18

Gravels, Pleistocene, deposition of

Pleistocene, gold in_-_-_-__-_ 65-66

Grubstake Bar, gold in_._._._._. 107

H.

Hammond Creek, gold deposits on

Hodzana highland, plates showing -- 12 topography of

Hodzana River, description of _..._- 21-22 gold prospects on

I.

Intrusive rocks, distribution and character of _..._._ 41-43

Mesozoic, distribution and character of _._.

W. C. Mendenhall on

Ironside Bar, gold in 107

J.

Jim Gulch, gold deposits on 107-108

Jim River, description of $25-26$

John River, tributaries of _._._._. 110 John River area, rocks of, distribution and character of ${ }_{-} 44-45$

K.

Kanutl River, description of lavas on

Kanuti series, rocks comprised in.-. Kelly Gulch, gold production on ....-

Koyukuk-Chandalar region, geologic map of _._._._._. In pocket

limits of showing -..........

rocks of, distribution and character of

timber in, figure showing _._._. 28 topographic map of - - In pocket.

Koyukuk district, extent of _..._._._ 83-84 gold lodes in, possibility of
Koyukuk River, Middle Fork of, description of -

Middle Fork of, flats on, plate showing -...-_.-_ 14

gold placers on

North Fork of, tributaries of _-_ 108

South Fork of, description of _-- 23-25

tributaries of

tributaries of _..._._._._._._._. 22-23

Koyukuk series, correlation of _._._- 54-55

L.

Lake Creek, description of

gold deposits on

Lake quartzite schist, distribution and character of .... 40-41

Lavas, Cenozolc, description of _... 56-58

Leffingwell, E. de K., survey by

Limestone, Carboniferous, age and correlation of _..._._. $52-53$

Carboniferous, occurrence and character of -_._-_ 51-52

cliffs of, plate showing ..... 34

contact of, with schist, plate showing -...-...- 34

Linda Creek, gold deposits on Little Squaw Creek, gold deposits on $\quad 113$

M.

Mammoth Creek, prospecting on _-_ 116

Marion Creek, gold deposits on _.._ 90

Mascot Creek, gold deposits on --- 108-109

Mendenhall, W. C., cited $--10,13,36,50,56$ on Kanuti River._._._-_._- 23

on the Kanuti River lavas_...- $\quad 57$

on the rocks of the Dall River

area

survey by

Mesozoic rocks, nature and distribution of

Metamorphism in the Birch Creek schist, discussion of _._ 47-49

Midas Creek, gold deposits on _.... $\quad 110$

Mining, cost of methods of

Minnie Creek, gold deposits on_._-- 94-95

Mosquito Creek, description of _... 25

Mule Creek, gold deposits on _.... 104-105

Myrtle Creek, dike on, description of - $\quad 43$ gold deposits on valley of, plate showing _._._. 86

N.

Nolan Creek, gold deposits on_-_-_- 92-94 plates showing

o.

Orenzik River, description of 21-22

P.

Paleozoic rocks, nature and distribution of _......... 49-58 
Peters, W. J., fleld work by survey by

Phoebe Creek, gold prospects on Placers, bench, features of classes of

deep, mining of

present stream, features of shallow, mining of

Pleistocene deposits, distribution and character of

Population, distribution of

Porcupine Creek, gold deposits on

Prindie, L. M., cited.

Prospect Creek, gold prospects on

\section{Q.}

Quartz, gold-bearing, veins of -_-_ 111-115 Quaternary formations, distribution and character of. $58-67$

\section{R.}

Rapids schist, distribution and character of $39-41$

Reaburn, D. L., field work by _._._. 10 Recent deposits, distribution and character of ....... 66-67

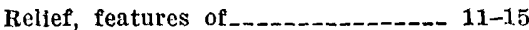

Robert Creek, gold prospects on _._. 104

Rose Creek, gold deposits on_...... 86

\section{S.}

St. Marys Gulch, gold deposits on_ 111, 116 Schist, contact of, with limestone, plate showing -...-.. 34

Schrader, F. C., cited__...... 9, 10, 17, $38,50,52,54,55,56,61,62,68$ on glaciation in the Endicott Mountains

on the Rapids, amphibolite, and Lake quartzite schists_ 39-41 on the Totsen series__._._._. 44,45 report by surveys by_...... 7, 8, 9, 9-10, 104

Sheep Creek, gold prospects on _._- 105 Sheep Gulch, gold deposits on
Page.

Silt bluffs, Pleistocene, plate showing - 58

Silver, production of _..._... 70

Skajit formation, correlation of _-_- 52-53

slate Creek, dike on, description of _ 43 gold deposits on_..._._._._-86-88

Smith, P. S., clted 7 report by, on the Noatak-Kobuk reglon_....... 7

Smith Gulch, gold deposits on_._. 92-94

Spring Creek, gold deposit on _.... 110

Spruce Creek, gold prospects on_-_- 105

Spurr, J. E., clted_____ 36, 39

Swift Gulch, gold deposits on

T.

Tertiary formations, distribution and character of

Timber, distribution of, map showIng

Tobin Creek, gold deposits on ..... 112

Totsen series, occurrence and charac. ter of -

Tramway Bar, gold deposits at_-_- 84-85 Transportation, facllities for... 30-32, 115 Twelvemile Creek, gold deposits on

U.

Union Gulch, gold deposits on _._._ $\quad 95$ v.

Vegetation, nature of ............ 28-29

Vermont Creek, gold deposits on _._- 97-98

W.

Washington Creek, gold deposits on 108

Water supply, sources of

Wild River, tributarles of _._._._ 109-110

Wilson Creek, gold prospects on _._. 107

Wiseman Creek, prospecting on_.._ 91-92

Witherspoon, D. C., field work by _.

Y.

Yukon Flats, description of ....... 11-13 